\title{
EXPERIMENTAL INVESTIGATION ON THE RELATION BETWEEN THE BRAIN AND THE INTERNAL EAR FUNCTION
}

\author{
By \\ G. ISOJIMA \\ From the Department of Oto-Rhino-Laryngology Nagoya University \\ Medical School (Director: Prof. S. Goto)
}

The variation of cochlear microphonics was observed in normal and decerebrated ginea pigs after the injection of several drugs into the carotid and vertebral arteries, or electrical stimulation to the cerebral cortex.

Following results were obtained :

1) Chemical or electrical stimuli on the central nervous system were reflected to the internal ear as circulatory or respiratory disturbance. Thus, they depressed or disturbed the energy. production process in the internal ear. Consequently, the balance between the energy production and consumption process were disturbed and depression of cochlear microphonics was observed.

2) When the balance between autonomic nervous system and central nervous system unified at the level of central cortex was disturbed, this was reflected to the internal ear as circulatory or respiratory disturbance and the depression the cochlear microphonics was observed.

\section{脳と蝸牛機能との関係についての実験的研究}

\section{名古屋大学医学部耳悬咽㑨科学教室 (主任：後藤修二教授)}

磯島息意

目次

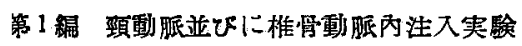

第1章 緒言

第2 章 実験装置並びに実験方法

第1節実験裝置

第 2 節 実験方法

第3章 频動脈內注入実䮖

第 1 箕実験方法

第 2 節 実験成結

第 1 項 $\mathrm{K}$ 塩, $\mathrm{Na}$ 塩注入实䮦

第 2 項 $\mathrm{CN}$ 化合物注入実驗

第3 项 空气 - 油注入実䮖

第4 项 アセチルニリン注入実弱

第 4 章·椎骨動脈内注入実験

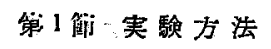

熋2 公䒠験成精

第 1 项 $\mathrm{K}$ 塩， $\mathrm{Na}$ 塩泩入实呀

第2 項 CN 化物泩入实娩
第3 頊 空氛・油注入実婏

第 4 項 アニチルニリン注入実験

第 5 章 総括並びに考按

第6 章 䌐語

第 2 編 除脳動物の頸動脈並びに椎骨動脈內注入实験

第 1 章 緒 言

第2 章 実験方法

第3章実硕成綪

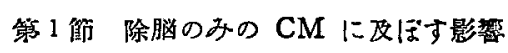

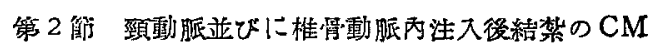
に及洨す影垶

管 3 䲝 除脳動物の頸動脈內 $\mathrm{KCl}$ 注入実験

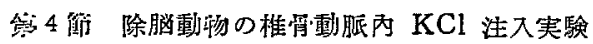

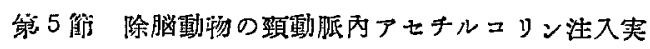
験

第6 節 除脑動物の椎骨動脈內アセチルコリン注入 実験

第 4 章 総括並びに唀按 
镜 5 絬語

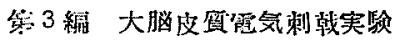

的 1 章 緒旁

管 2 章 実験方法

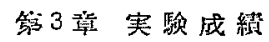

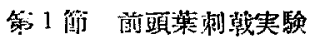

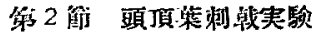

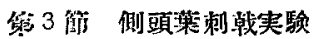

篹 4 諙 後頭荣刺戟実驗

第 4 章 総括並びに洘按

第 5 裳 結語

参考 交 献

第 1 編 頸動脈並びに椎骨動脈内注入実験

\section{第 1 章 緒 言}

「身体の支配器官」と呼ばれている畄は物理的な意昧 での外部活動を殆んど行つていないし，化学的外部活動 む極めて砗かなるのである. 又その電気的外部活動に和 いても，脳のブドウ糖代謝によつて生ずる熱量 $12 \mathrm{zal} / \mathrm{g}$ /時の一部を消費するに過ぎない.かくて，12cal /g 時 という熱量の 相当部分が脸の構造と 反応淮備性の 維持 に，即ち，活動電位の依存している $\mathrm{K}+と \mathrm{Na} \div$ の1 オン勾配の維持に，又，インパルスのシナップス伝澾上 細胞間の相互作用に，更には神経細胞自体の代謝的約構 の更新に消預されるが，成人の脳はその重量の $2 \%$ に過 ぎないにも拘らず，心搏出量の $1 / 6$ の血行量を受オ， $\mathrm{O}_{2}$ 消費量は全身消毒量の $20 \%$ にる及び，毎時消費さ れるブドウ糖が $4 \mathrm{gr}$ に達することは脳の機能的活 動が極めて旺盛なことを物語つている (Kety et al ). 又,この機能活動の旺盛なる脳の外部活動力゙僅 少なことは，その主要袎能が広箕且つ高度に体制化 された統侥作用にあることを示唆するものである。

内耳も攵当然かる脳の統御的支配下にあつて， その調節作用によつて初めてよく，その機能が維持 できるものと考えられる.そこで,内耳機能の全貌は脸 との関連を無視しては充分に把摼できないことは明らか であり，従つて，「脳と内耳㭫能」との問题が多大な䦎 心と斯待の下に多方面から研究されてきたのであるが， 未だその知見が充分とは云い難い現洗にある。

ところで, 1930 年 Wever 及び Bray 9)は除腦猫の

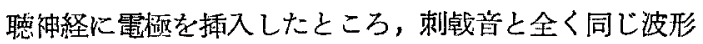
の電流が生ずっことを発見し、これが聴神経の活動電位 であると発表した・Adrian（1931）は彼管の見解が䛠 りであり，この現象は蝸牛内に一檑のマイクロフォン效 果があるためだとし，以来，この現象をCochlear Microphonics (以下 C.M. と略す) と呼ぶこととなり， これが蝸牛のいかたる部位で，どのよらな性状をもつ

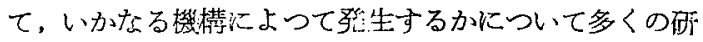
究が相㳄、で行われてきた・が一方，これらの問題が漸

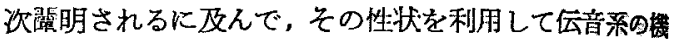
能を，又伝音系の正常な場合には，各種条件下のコルチ 器, 殊に有毛細胞の態度を研究する手段として利用され るようになつた・私は、かつる C.M. を指標として、聤 覚璣能の中枢㙨序を解明する一助として，次の如き象歌 を行つた。

\section{第 2 章 実験装置並びに帘験方法}

第 1 節 実験装置

本装置については，先に教空の加藤3)が詳細に検討報 告し—衫り，私の使用した装置むこれと全く同一の6の であるので，概略を記するにとくめる・

その Block Diagram は第1図の如くである・

第1図 Block Diagram

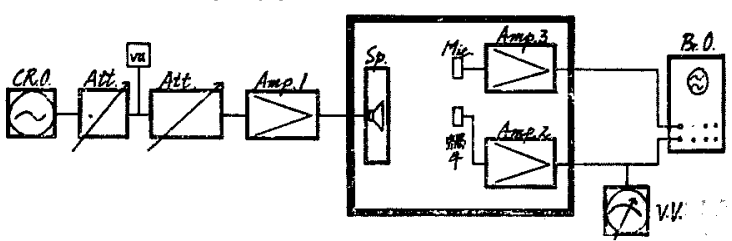

即わ，a）音源系装置としては，

1) C.R.O.： 湘沓 1 号 CR 発振器 (横河製)

2) Att.：測搬 90 型 4 号 A 抵抗減䤠器 (横河製)

3) Amp. 1: 電力堌幅器

4) Sp.：8时パイれア・スピーカー（パスレフ型 スピーカー・ボックスに装着)

5) V.U.: V.U. メーター（悪河整） を用い，b）反灾测定系装䈯としては，

1) 雷㥛： $200 \mu$ の銀線並びに鉭板

2) Amp. 2：電生增幅器（最大利得 $120 \mathrm{db}$ )

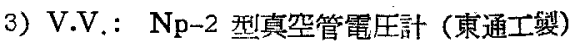

4) Br.O.： 二光軸ブラウン管オッシロスニーブ を用い，c）登音体観測系㸚置としては，

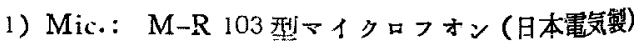

2) Amp. 3: 電圷境幅器 (最大利得 60db) 
3）Br.O.：二光軸ブラシン管オッシロスコープ 伐用した。

第2節 実駼方法

実験動物には，400〜500gr のブライニル反射良好な る正常成熟モルモットを使用し，先ず，0.5\%クロール ブロマジン 3〜 5ml, 10\%ロレタン水溶液 3〜6ml を腹 腟内《注射した後，全身状態の安定するのを待ち，背 位烟定し，頸部に正中切開を加光，予め気管切開を施 行したる後，頸部より中耳骨胞を籍出，その骨蓝に開孔 して䋸牛を簬出乙，蝸牛第 3 回転骨壁にエッメルをるつ

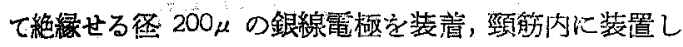
た不閣電極を接地せしめた。

次いで， CR 発振器上り刺战音を発振させ，自由音埸 を作り、ブラウン管オッシロスコーブにて刺战音波形と

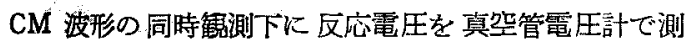
定した.

反応強度特性曲線は，縦軸汇反応電圧を log-scale そり，雬軸䎲音源系の Intensity linear-scale で示 し，正常時之操作時の反応強度特性曲線の直線部分に特 いて，同一反忘電圧を得るに要する Intensity の移秐

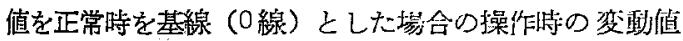
として，各周波数につき記録した。

以上の実駼杜すべて電気的に遮蔽された防管室内で行 つた.

\section{第 3 章 額動脈内注入実験}

第1 節 笑験力法

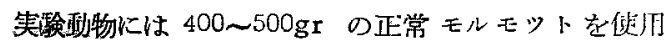
し，前章記述の荠置並びに万法により C.M. を観測記 録した。

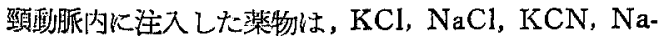
$\mathrm{CN}$, 空気, ダンピング油及ひびアセチルコリンである. 注入方法は，1/4 注射針をるつて上記薬物を一側総頸動 脈内注入し，注入後時間を追つて测定した C.M. 值 の周波数特性曲線を，注入前の C.M. 值を基潐にして

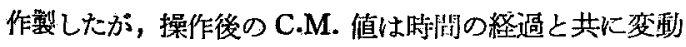
するので，その誤差を少なくするため C.M. 湘定䐓序 蒙常任低音より高音へと一定にした・がしかし，これに よっても低音に和ける変動值之高音に和ける变動值とは 全く同一時間でないことによる誤差は避污られない。

籍 2 節 実煥成績

第 I項 $\mathrm{K}$ 塩; $\mathrm{Na}$ 塩注入実驗： $1 \mathrm{Mol}-\mathrm{KCl}$ 及び $\mathrm{Na} \mathrm{Cl} 0.5 \mathrm{ml}$ の頸動脈内注入による C.M. 変動值を各 周波数の平均値をるつて一括表示すれば，第 1 表及び第
2 表の如くである。

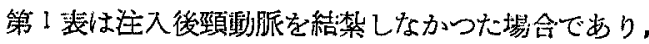
第 2 装は注入後結紮した場合である。

第1表 $1 \mathrm{Mol}-\mathrm{KCl}$ 及び $\mathrm{NaCl} 0.5 \mathrm{ml}$ 頖動脈 冈柱入後の C.M. 変動值 $(\mathrm{db})$

\begin{tabular}{|c|c|c|}
\hline 注入莱物 & kce & $\mathrm{NaCl}$ \\
\hline 動物番是 & 123 & 123 \\
\hline $\begin{array}{l}1 \sim 50 \\
15 \sim 200\end{array}$ & & $\begin{array}{l}-1.1-2.0+ \\
-1.9-18+\end{array}$ \\
\hline
\end{tabular}

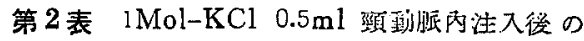
C.M. 将動值 $(\mathrm{db})$ (注入後結禁)

\begin{tabular}{|c|c|}
\hline 動物翻号 & 123 \\
\hline / 分 & $-4.3-4.7-32$ \\
\hline $2 \hat{\jmath}$ & $\begin{array}{llll}-9.7 & -10.3 & -8.1\end{array}$ \\
\hline 3 分 & $-6.8-104-6.5$ \\
\hline $5 \hat{\jmath}$ & $-1.3-0.4+0.9$ \\
\hline
\end{tabular}

注入後，頸檕脈を結禁しない埸合の C.M. 変䟞は極 めて少なく，その損失值は $\mathrm{KCl}$ 注入で㥗 2 3db, $\mathrm{Na}$ $\mathrm{Cl}$ 注入では 1 2db で， $\mathrm{KCl}$ 注入時にや」大である. ところが， $\mathrm{KCl}$ 注入後結禁した場合の C.M. 損失は 急速加著明に現れ，注入 2 分後に $10 \mathrm{db}$ に達した

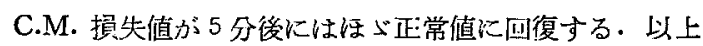
の成领から，C.M. 維持沉は一定の閔檤の存在すること が暗示される，即ち，注入後結紫する，しないによる $\mathrm{KCl}$ の濃攸差が C.M. の変動炕斯く沃定的な差をむた らしたと考えられるからである. 尤も，この際，頸怔脈 綃柴だすでは C.M. 変哺が認められないからと云つて， 繥枈に上る脳欰行の一過性制限が潜在因子として C.M. に影響を与学ないとはい〉難い. 又, この際の C.M. 変 泓山速やかに終過し，而もその洔間的スケールが損失過

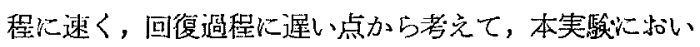
ては，その操作上各実験例の夫たの周波数を企く同一悰 間に測定することは不可能であるので，その周波数特性 は各䒠騃群归の1例をむつて代表せしめだ・

$\mathrm{KCl}$ 及び $\mathrm{NaCl}$ の周波数特性悔第 2 図から第 4 図に 示す通りである。

第 2 図は, $1 \mathrm{Mol}-\mathrm{KCl} 0.5 \mathrm{ml}$ 頸動脈内注入後の C.M. 損失の周波数特性であるが，注入 1 分後上り $2 \sim 3 \mathrm{db} の$ 低下が現れるが，その後は殆んど变動のないま小経過 
し，20 分後更に $0.5 \mathrm{ml}$ 觉追加注入生ると，その1 尔後 より C.M. 損失が加わり，注入前上りの損失は $5 \mathrm{db}$ 前 後となる. 更に 20 分後に多少回復するが，完全には注 入前に復さない。これらの周波数別美異は大差を認めな w.

第 2 図 $1 \mathrm{Mol}-\mathrm{KCl} 0.5 \mathrm{ml}$ 頸動胙內注入例

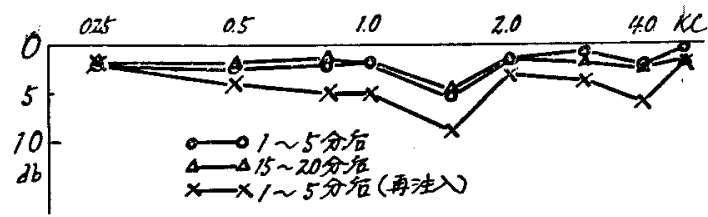

第3 図は，1Mol-KCl $0.5 \mathrm{ml}$ 頸動脈内注入直後に結 紮した場合の周波数特性である.注入1分後には $10 \mathrm{db}$, 2 分後には $20 \mathrm{db}$ の損失をきたすが， $20 \mathrm{db}$ を越えない. その後比較的速やかに回復して5 分後にははづ正常值に 達する.斯く C.M. 变動が急速に経過するため, 各周波 数別差異を同列には論じ難いが，低音域にや〉損失著㛣 の傾向が認められる。

第 3 図 $1 \mathrm{Mol}-\mathrm{KCl} 0.5 \mathrm{ml}$ 频動脈丙注入俳（泣 入直後絬紫)

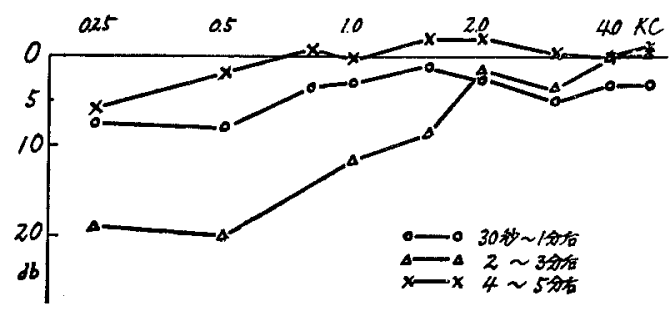

第 4 図は $1 \mathrm{Mol}-\mathrm{NaCl} 0.5 \mathrm{ml}$ 頸動脈內注入後の周波 数特性であるが，殆んど变動が見られないたた 4,000 c/sで $10 \mathrm{db}$ に近い損失を見たなっ回復しないが，これ は注入中より現われた痤画と，これに伴う呼吸障碍のた め, 内耳に和ける不可逆的变化分部分的に局在して起つ たつめと考えられる。

第 4 图 $1 \mathrm{Mol}-\mathrm{NaCl} \quad 0.5 \mathrm{ml}$ 頚動胝內注入例

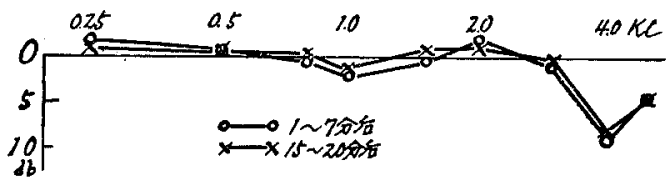

第 2 項 $\mathrm{CN}$ 化物注入実験： $1 \mathrm{Mol}-\mathrm{KCN}$ 及び $\mathrm{Na}$ CN $0.05 \mathrm{ml}$ の頸動脈内注入後の C.M. 損失值を各周波 数の平均値をるつて一括表示すれば，第了表の如くであ
り，又，その周波数特性を図示与れば第 5 図及ひ第6图 の如くである.

第 3 表 1Mol-KCN 反び $\mathrm{NaCN} 0.05 \mathrm{ml}$ 顆 艃脏內注入後の C.M. 摃尖值 (db)

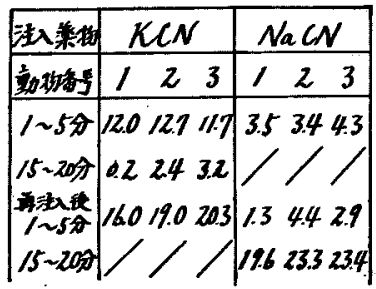

第 5 图 $1 \mathrm{Mol}-\mathrm{KCN} 0.05 \mathrm{ml}$ 頚動梳內注入例

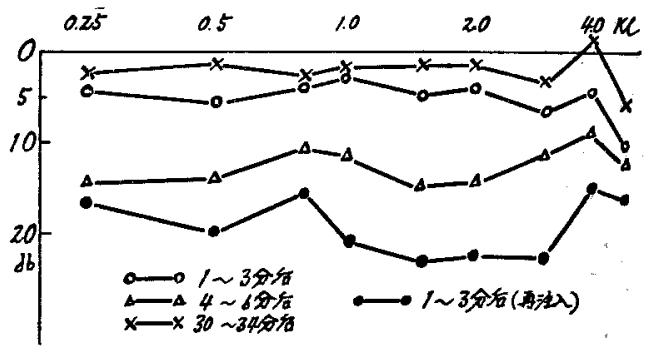

第 6 图 $1 \mathrm{Mol}-\mathrm{NaCN} 0.05 \mathrm{ml}$ 到動腿內注入例

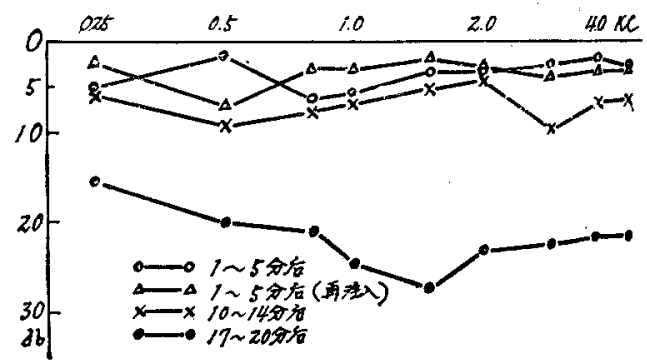

これら CN 化物这入実験に蛙いてはいずれる注入後 頸動脈結紫を行つていない.

$1 \mathrm{Mol}-\mathrm{KCN} 0.05 \mathrm{ml}$ 注入では注入直後には $5 \mathrm{db}, 5$ 分 後には 10〜15db 損失した C.M.は，20分後には2 $3 \mathrm{db}$ の線まで回復するが，これに0.05ml を再注入する と，急速に 20db まで低下して回復しない.

$1 \mathrm{Mol}-\mathrm{NaCN} 0.05 \mathrm{ml}$ の注入では, $\mathrm{KCN}$ 注入時机比 して C.M. 損失が少なく，3〜 5db で，回復も殆んそ証 められないが，これに $0.05 \mathrm{ml}$ を再注入するとその直後 の損失は少ないが，15 分後より急速な低下を示し,20 $25 \mathrm{db}$ の損失值を示したな〉回復しない，又これらの 周波数別損失値には大差を認めない。

以上の実験成績から，CN 化物更又 C.M. 維持に椷 
して一定の限界濃度 (はよ゙ 10-4M) があり，この濃度 越光る C.M.小急速に低下するが，又，CN 化物注 スによる C.M. 損失は $\mathrm{CN}^{-}$による影響たけでなく， これに加えてK+， $\mathrm{Na}^{+}$の潜在的影響も考党られ，而も K+による影響の力が大きいことが偣示される・

第 3 項，空気，油主入象耠： 空気 0.1 及び $0.2 \mathrm{ml}$, ダ ンピング油 0.1 及び $0.2 \mathrm{ml}$ の頸動脈内注入による C.M. 損失值を各周波数の平均值をるつて表示すれば第 4 表の 姐くであり，又，夫々 $0.2 \mathrm{ml}$ 注入による周波数特性は 第7図及び第8図の通りである・これらはいずれも注入 直後に頸動脈結禁を行つた。

第 4 表 学気及び油の 0.1 と $0.2 \mathrm{ml}$ 形動脈內注 入後の C.M. 变動值 $(\mathrm{db})$

\begin{tabular}{|c|c|c|c|c|}
\hline 洼入物 & \multicolumn{2}{|l|}{ 空 } & \multicolumn{2}{|c|}{ ダンピンブ油 } \\
\hline 注入里 & $0.7 \mathrm{ml}$ & $0.3 m e$ & $0.1 \mathrm{me}$ & a. $2 m e$ \\
\hline 第物备是 & 123 & 123 & 123 & 123 \\
\hline $1 \hat{\pi}$ & $0.5 \quad 0.30 .5$ & $9.8 / 0.2 / 3.1$ & $\begin{array}{lll}0.3 & 1.2 & 0.7\end{array}$ & 9.4817 .9 \\
\hline $2 \hat{\jmath}$ & $0.8 \begin{array}{lll}0.6 & 0.8\end{array}$ & $\begin{array}{llll}18.5 & 20.8 & 22.6\end{array}$ & $0.3 \quad 140.7$ & $13.1 / 2.89 .5$ \\
\hline $3 \sim 59$ & $\begin{array}{lll}0.6 & 0.5 & 0.3\end{array}$ & 20323.2343 & 5.76 .55 .5 & 30.818 .314 .4 \\
\hline
\end{tabular}

第7図 等気 $0.2 \mathrm{ml}$ 頚動胙內注大例

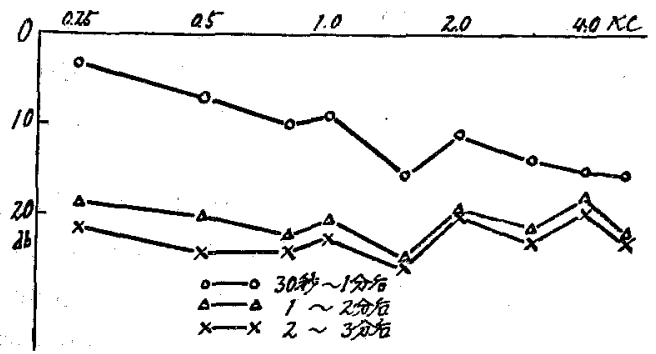

第 8 図 ダンビング油 $0.2 \mathrm{mI}$ 新唾脈內泩入例

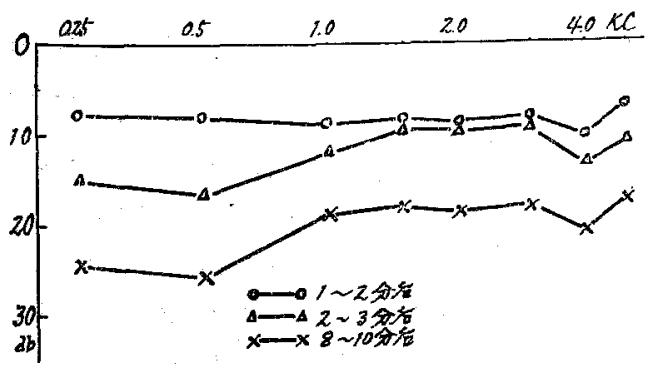

$0.1 \mathrm{ml}$ の空気を注入・結紮した場合には C.M. 損失 は殆んど認めらわないが，0.2ml を注入した場合には， 30 秘後より急速低に下し始めた C.M. は，1〜2 分後に

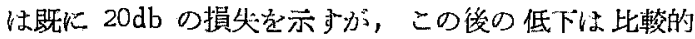
少なく，注入 10 分後には呼吸停此し，心搏動も停止す 西.

$0.1 \mathrm{ml}$ のダンビング油を注入・結棌した埸合には，注 入後 い〜2 分後には殆んど C.M. 損失が認められないが， 5 分後には 5〜6db の損失を示したま〉回復しない. 0.2 $\mathrm{ml}$ を注入した場合には空気注入例と同椂, 注入後 C. M. は急速に低下し，1 分後には8〜10dbに潞し，その 後以比較的緩慢に低下を続す，5分後には 201 の損失 值に達する・更にその後は殆んど回復を見ないま小経過 する。

以上の成續吕ら，C.M. 維持匹血行のもつ意義の重要 性が示㖫される・空気及び油を注入すれば，栓塞による 血管㲘縮を若若するすのと考えられるからである。

第 4項 アセチルコリン注入実験： アセチルコリン $3.75 \mathrm{mg}(12.5 \mathrm{mg} / \mathrm{dl})$ 及び $5 \mathrm{mg}(12.5 \mathrm{mg} / \mathrm{dl})$ 頸動脈 内注入後の C.M. 変㖵值を各周波数の平均值をもつて一 括表示すれば，第 5 㳖の如くであり，その周波数特性は 第9図に示す通りである・これらはいずれも注入後結禁 を行つた場合である。

\section{第 5 表 アセチル コリン頸動胙內泆入後の} C.M. 变雲值 $(\mathrm{db})$

\begin{tabular}{|c|c|c|}
\hline 注入是 & $3.75 \pi g$ & $5 \mathrm{mg}$ \\
\hline 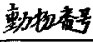 & 123 & 123 \\
\hline $1 \hat{x}$ & $5.65 .6 \quad 9.5$ & 6.86 .24 .9 \\
\hline $3 \pi$ & $/ 3.4 / 8.7$ & 15.016416 \\
\hline & & \\
\hline $15 \hat{\lambda}$ & 0.63 .0 & \\
\hline
\end{tabular}

第9图・アセチルニリン頸動胝內注入例

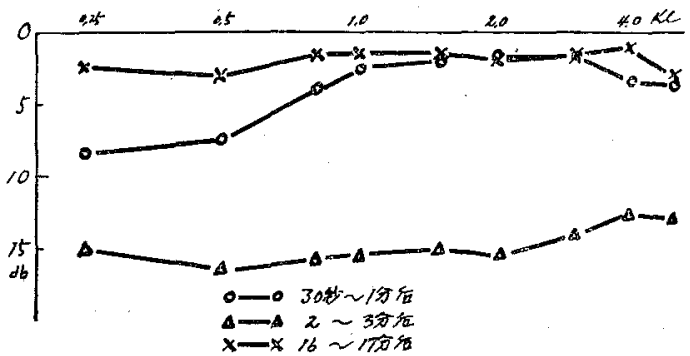

$3.75 \mathrm{mg}$ の注入では，1分後には $5 \mathrm{db} ３$ 分後には 10 〜15db の損失を亦し，その後緩慢な回復過程をとり， 15 分後には 2〜3db の線に達する. $5 \mathrm{mg}$ の注入では， 
一般に1分後には 5 6db，3 分後には $15 \mathrm{db}$ を越之，5 分後には 20db に達し，その後は回復を示さないが，5分 後にはほら゙回復する場合もある・又，周波数別差罢は低

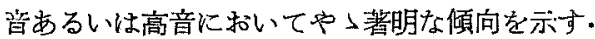

以上の如き各種桨物の頸政脈内注入矢験を通じて共通 の特異点は，C.M. 低下゙が䔉物注入によって萑起される 全身痤柰之乎吸障碍の程度及び持続時間に平行的に消長 することである。

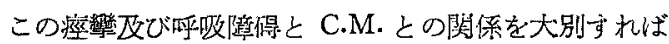
次の三型に分数できる・即ち，第一に，注入と同時に発 現した痤繁の消失媛，呼吸障碍を伴方ない場合で， $\mathrm{KCl}$

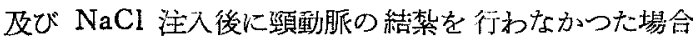
と，空気及び油》 $0.1 \mathrm{ml}$ を注入し心場合とに見られ，

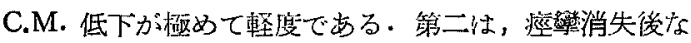
㸰一過性呼吸停止が持続し，その後過呼吸状態を経て正 常呼吸へ移行する場合で， $\mathrm{KCl}$ 注入後結倠した場合と， Ach $3.75 \mathrm{mg}$ 注入の瑒台とに見られ，C.M. は急速かっ 著明に低下するが，後ほぶ正常值になで回復する・第三

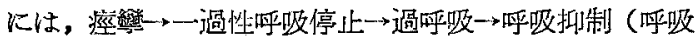
微氜岛，呼吸数減少） $\rightarrow$ 呼吸停止 $\rightarrow$ 死の経過を辿る場合 で, CN 化物, 空気及び油 $0.2 \mathrm{ml}$, Ach $5 \mathrm{mg}$ 注入の憬 合に見られ，C.M. は急速から決定的に低下し，死に至 るまで殆んど回復の傾问を圭さない。

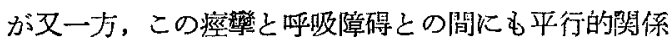

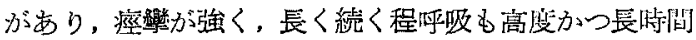
に亘つて障㥂され，その際の C.M. 低下はより早期に始 まり，回復にはより長溇間を要する。

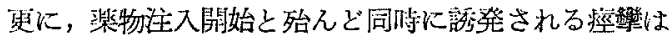
数秒以内に消失し，その後に持続するる過性の呼吸停止 头注入 10 秒前後には過呵吸に移行し，注入 $2 \sim 3$ 分後に は正常呼吸に四復するにも拘らず，C.M. の回復過程は

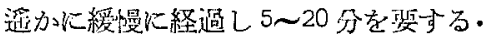

\section{第 4 章 椎骨動脈内注入実験}

约1 節 䒠䯝少法

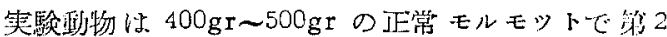

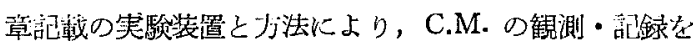
行つた.

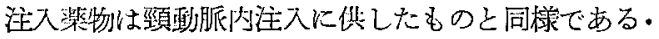
注入方法は，先ず右側鎖骨下動脈を椎骨動脈末梢で結禁 し，次いで同側頸動脈を結森，注入眻薬物の頸動脈内一 迹流するのを防ぎ，1/4 注射針により腕頭動脈内へ所装

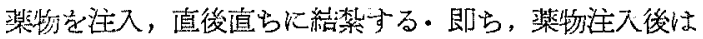
右側の莖䖝脈㱏びに惟骨動脈の血行は遮断されるるけで
ある. 実験成續は注入後 C.M. 值の周波数特此曲線を， 注入前 C.M. 值を基準にして表わしたが，C.M. 浿定犆 序は頸動脈内注入笑験の埸合之同様，常に $250 \mathrm{c} / \mathrm{s}$ より 始め 5,000c/s に終るようにした。

第 2 節 笑駼成績

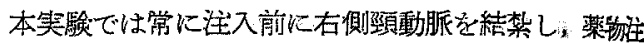
入直後后，側椎骨㲜脈の血行を遮断しているので，先ざ れら血行遮断の C.M.に及ぼす影響について檢討を加党 た・これによると，一側の椎骨㖶脈・頸動脈の紜䋈で妒 C.M. 低下は $5 \mathrm{Jb}$ 以内炏とざまる．次に最る低下の甚 しかつた 1 例を示过，第10 図の如くである。

がしかて，これに他側の椎骨動脈絽禁を加えると，結 禁 5 分後に $5 \mathrm{db}$ 低下した C.M.は，15 分後には $10 \mathrm{db}$ ， 更にその後急速に低下を加光 20 分後には 20 30db K 至ると共に，呼吸数は著明に減少し，結紮 25 分後儿死 亡している。

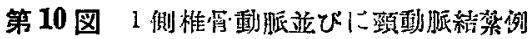

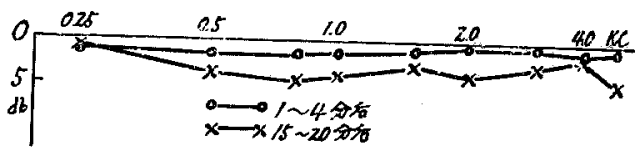

以上の成續上り，1 側の椎骨動脈並びに 䫓動脈結禁に

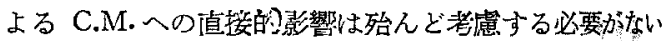

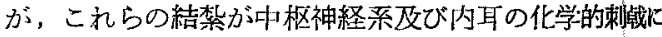
対する受傷性を高福る可能性については否定できない だろう。

第 1 項 $\mathrm{K}$ 塩， $\mathrm{Na}$ 塩注入実娩： $1 \mathrm{Mol}-\mathrm{KCl}$ 及び $\mathrm{NaCl} 0.5 \mathrm{ml}$ の椎骷動脈內注入による C.M. 損失値を 各周波数の平均値をむつて一括装示与れば籍 6 丧の如く であり，夫ミの周波数特性は前章で述べた理由から各䒠

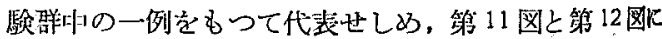
示す通りである.

$1 \mathrm{Mol}-\mathrm{KCl} 0.5 \mathrm{ml}$ の注入では，在入 30 秒後には既下 $15 \mathrm{db}$ に及占損失を示した C.M. は，1２分後には 20

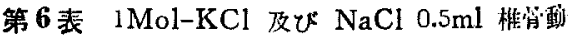
眼內注入後の C.M. 損头值 $(\mathrm{db})$

\begin{tabular}{|c|c|c|}
\hline 注入耗时 & KCe & NaCl \\
\hline 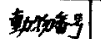 & 123 & 123 \\
\hline $1 \hat{0}$ & 12.415 .744 & \\
\hline $2 刃$ & $200 / 38 / 79$ & \\
\hline 50 & $\begin{array}{lll}11.6 & 7.5 & 6.8\end{array}$ & 5.7293 \\
\hline
\end{tabular}


第 11 图 $1 \mathrm{Mol}-\mathrm{KCl} 0.5 \mathrm{ml}$ 椎愲動胙內注入例

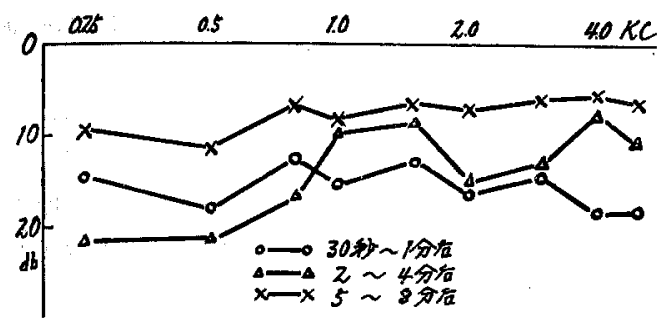

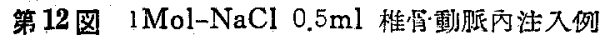

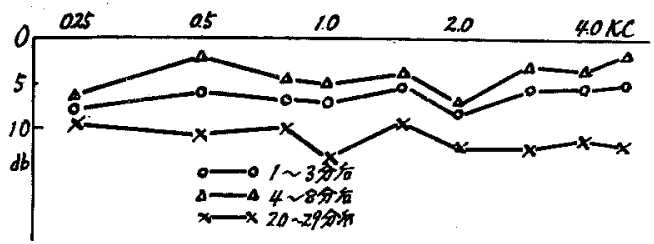

$\mathrm{db}$ にまで低下゙し，その後漸次回復に向らが，この回復 過程は緩慢に経過し，5 分後に $10 \mathrm{db}$ 以内， 15 分後に $5 \mathrm{db}$ 以内に市で回復する。

$1 \mathrm{Mol}-\mathrm{NaCl} 0.5 \mathrm{ml}$ の注入では, 注入 1 分後には6〜 $7 \mathrm{db}$ の損失を示し，5分後には 3 5db に夏で回復する が，その後再び徐々に低下を加えるる10db の線を大き く越えない。

$\mathrm{KCl}, \mathrm{NaCl}$ の椎骨動脈注入では頸動脈闪注入に比し て変動差が大きいように見えるが，これ注入直後汇結

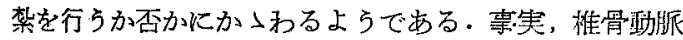
内注入後結紮を行わなかつた場合には誌むべき C.M.の 変動差を握み得なかつた・

第2項 CN 化物注入実驗：1/10 Mol-KCN 及び $\mathrm{NaCN} 0.5 \mathrm{ml}$ の椎骨動脈内注入による C.M. 損失値を 各周波数の平均值をもつて一括表示すれば，第 7 表の如 くであり，夫々の周波数特性は第 13 図，第 14 困に示す 通りである。

第 7 表 $1 / 10 \mathrm{Mol}-\mathrm{KCN}$ 攻び $\mathrm{NaCN} \quad 0.5 \mathrm{ml}$ 椎 骨動脈內注入後の C.M. 損火值 $(\mathrm{d} b)$

\begin{tabular}{|c|c|c|}
\hline 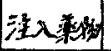 & $K \subset N$ & $\mathrm{Na} C N$ \\
\hline 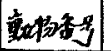 & 123 & 123 \\
\hline 10 & 3.75 .56 .7 & 2.42 .343 \\
\hline $2 \gamma$ & 73929.7 & 4.08 .345 \\
\hline 5 分 & 13.616 .813 .6 & 4.512 .7 .1 \\
\hline $15 \hat{\lambda}$ & 死亡 & $17224.5 \% 6$ \\
\hline
\end{tabular}

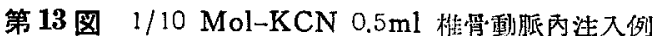

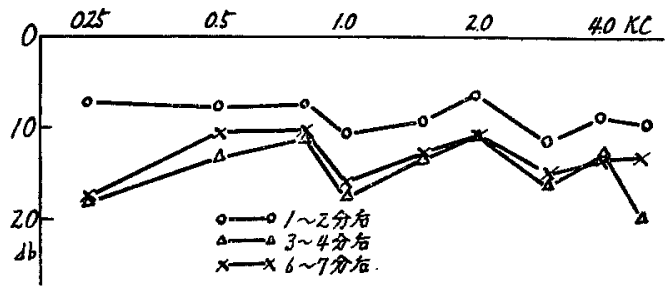

第 14 图 $1 / 10$ Mol-NaCN $0.5 \mathrm{ml}$ 椎骨政腿內注入例

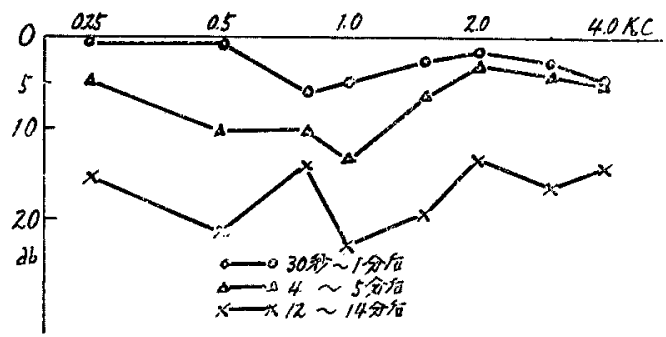

1/10 Mol-KCN $0.5 \mathrm{ml}$ の注入では, 注入 1 分後 C. M. 低下は既に $10 \mathrm{db}$ に及び，3 分後には 10〜15db の 損失を見，その後呼吸障碍が一過性に回復を見せるよう な場合には C.M.も文や」回復の兆しを見せるが，注入 7〜10 分後には死亡する.

$1 / 10$ Mol-NaCN $0.5 \mathrm{ml}$ の注入では注入 1 分後のC. M. 低下は未た $5 \mathrm{db}$ 以内であり， 5 分後漸く $10 \mathrm{db}, 15$ 分後に至つてその損失は $20 \mathrm{db}$ に灭らかが，これは $\mathrm{KCN}$ 注入後の損失経過に比して遥か心綬慢に進行する。

第 3 項 空気及び 油注入実跧：空気 0.1 及び $0.2 \mathrm{ml}$ とダンピング油 $0.1 \mathrm{ml}$ の椎䆚動脈内注入後の C.M. 損 失值を各周波数の平均值をもつて一括表示すれば，第８ 表の如くであり，又，夫今の周波数特性を図示与れば， 第 15 図と第 16 図の通りである。

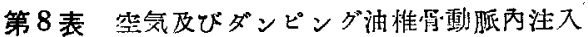
後の C.M. 摃失值 (db)

\begin{tabular}{|c|c|c|c|}
\hline 浩入软 & 空 & 氮 & 油 \\
\hline 注几量 & $0.1 \mathrm{mz}$ & 0.232 & $0.1 \mathrm{me}$ \\
\hline 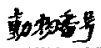 & 123 & 123 & 123 \\
\hline $1 \hat{\partial}$ & $0.3 \quad 0.5 \quad 0.5$ & 7.68 .29 .7 & 811.30 .5 \\
\hline$z \hat{x}$ & 0.60 .8 & $13.5 / 7018.0$ & $6.3 \quad 6.25 .8$ \\
\hline $3 \hat{0}$ & & & 11.611 .412 .7 \\
\hline 5 余 & & & $2.32 .8 \quad 7.5$ \\
\hline
\end{tabular}


第 15 図 等気 $0.2 \mathrm{ml}$ 椎惯動脈丙注入例

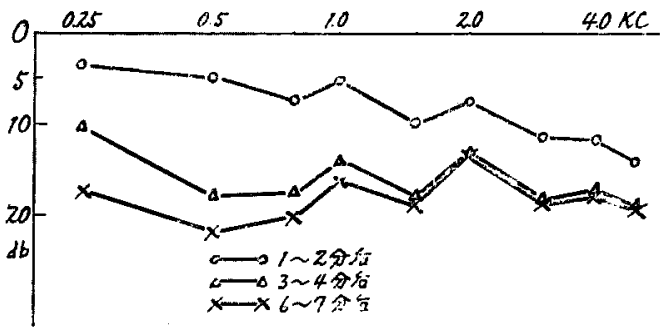

$0.2 \mathrm{ml}$ の空気注入では，注入直後に低下し始めたＣ． M. は，1 分後には既に $10 \mathrm{db}$ に及ぴ，2 分後には $20 \mathrm{db}$ の損失に至る・これは，頸動脈内に注入された場合とそ の損失の時間的経過が酷似しており，共に極めて短時間 に経過する。

第 16 図 ダンビング油 $0.1 \mathrm{ml}$ 椎骨動脈內泩入例

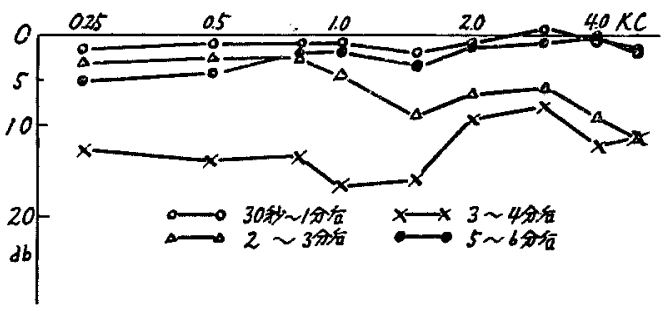

ダンピング油 $0.1 \mathrm{ml}$ の注入では，注入值後は C.M. の低下が殆んど現れないが，2 分 30 秒後より急速に下 降し，3分後には損失 $15 \mathrm{db}$ に至る・その後の回復も又 急速であるが，損失過程よりはや〉緩慢であり，5分 後には $5 \mathrm{db}$ 以内にまで回復するが，ダンビング油 0.1 $\mathrm{ml}$ の頸動脈内注入例では変動が少なかつた。

第 4 項 アセチル エリン椎骨動脈内注入実験：ア七 ヂンリンの椎骨動脈内注入後の C.M. 損失值を各周波 数の厌均值をむつて一括表示すれば，第9表の如くであ 万.

第 9 表

\begin{tabular}{|c|c|c|c|c|}
\hline 注入量 & $2.5 \mathrm{mg}$ & $3.75 . \mathrm{mg}$ & $5 \operatorname{seg}(1)$ & $5 \operatorname{son} g(x)$ \\
\hline 部和落里 & 123 & 123 & 123 & 123 \\
\hline$/$ 分 & $6.7 \mathrm{f} .1 \mathrm{l} .1$ & 4.5445 .3 & 9.58 .110 .7 & 5.23 .627 \\
\hline $3 \gamma$ & $2.3 \quad 6.7 \quad 7.8$ & $92 / 418.4$ & $/ 22 / 2 . / 1444$ & 14376.6115 \\
\hline 50 & 2.63 .64 .1 & 16.121 .186 .8 & 19.1212223 .3 & 9.21026 .5 \\
\hline 203 & & & & 4.21 .9 \\
\hline
\end{tabular}

即ち， $2.5 \mathrm{mg}$ の注入では C.M. 損失は比較的軽度で 注入 3 分後に休 6〜8db に及灾損失を見るが，5分後に
は 3〜4db にまで回復し, 3.75mg の注入では, 拄入1 分後には $5 \mathrm{db}, 3$ 分後には $10 \mathrm{db}, 5$ 分後には15〜20db と急速から著明に低下するが，回復逗程は縓慢に程成 し，漸く 20 分後に 2〜3db の線にまで回復する・とこ ろが，5mg の往入では，C.M. 損失が更に急速が著 明に現れ，1 分後には $10 \mathrm{db}, 3$ 分後には 10〜15db と暨 下し，5分後には20dbを越え，回復を見ないま口死 至る場合と，注入 1 分後の損失值は $5 \mathrm{db}$ 以内にと与゙ るが，3 分後には 10〜15db に達し，その後は回復過理 を辿り，5分後には $10 \mathrm{db}, 20$ 分後には $5 \mathrm{db}$ 以内にまて 回復する場合とがある・これら $5 \mathrm{mg}$ の往入によって回 復した場合と回復しない埸合の周波数特性を図示才れ ば，第17図と第 18 図の如くである・

第 17 図アセチル エリン $5 \mathrm{mg}(25 \mathrm{mg} / \mathrm{ml})$ 椎 婴動胝内注入例 (1)

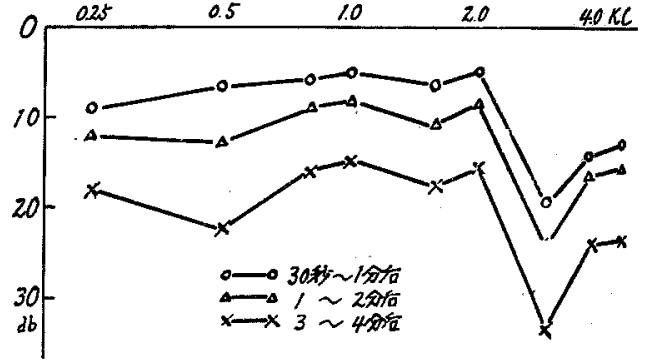

第 18 图 アセチルコリン $5 \mathrm{mg}(25 \mathrm{mg} / \mathrm{ml})$ 椎

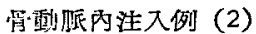

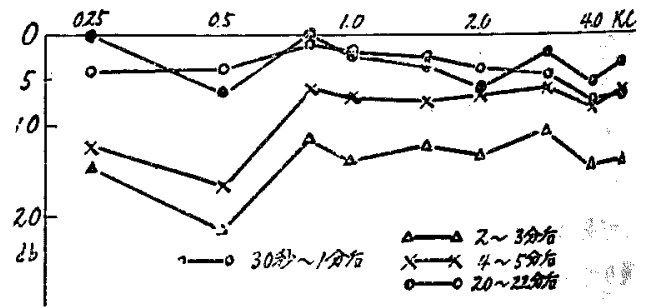

椎骨動脈内注入実験において子，各周波数の C.M. 定が全く同一時閻に行われないためと注入後の C.M.变 動が短時間内に消長するため周波数別の特異性を云々す ることは困難であるが，頸動脈内注入実驗の場合と同 様，殆んどが周㝿数別に大差を認め難いたな゙、アせチル コリン $5 \mathrm{mg}$ の注入時には低音及び高音に C.M. 損失の著 明な場合がある・又、これら椎骨動脈内注入実駼机いて \&，頸動脈内注入実験と同様，注入後の C.M, 变動は動 物の全身状態と筤接な関係がある. 即ち，C.M. 变動は

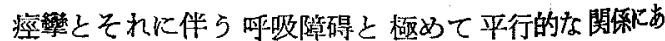




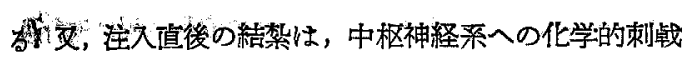

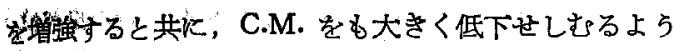

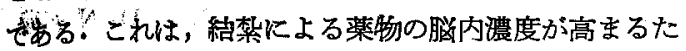
的考光られる. 又椎骨動脈内注入では, 项動脈内注入 火比して C.M. の変動が大き現れる場合すあるが，

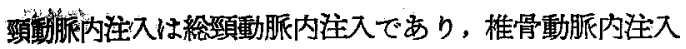

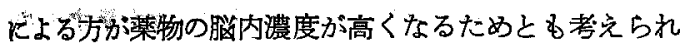
多.

\section{第 5 章 総括並ひに考按}

频勤脈並びに椎骨動脈内に注入された上記の薬物は中

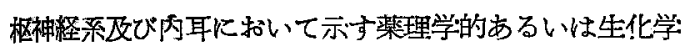
的態度を夫々累沉するであらら・しからばこれらの薬

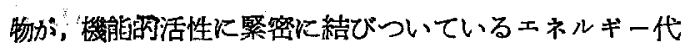

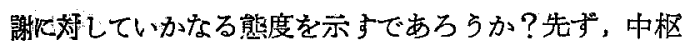
神释栾内で示す生化学的態度から述べる.

$\mathrm{K}$ 塩, $\mathrm{Na}$ 塩：脳細胞と直接しているのは閒質液で あり、これは毛細管壁によつて血液から分かたれ，脳室

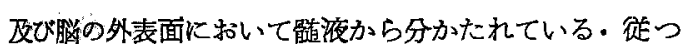
て; 脳成分は脳の浸されている体液之関保づけて語価さ

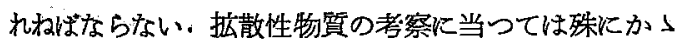
あ考慮が必要である。

盂流中の $\mathrm{Na}^{+} 中 \mathrm{Cl}^{-}$の变化が鹃液に充分反映され る飞传数時間が必要であり，又，放射性 $\mathrm{Na}^{\circ} \risingdotseq \mathrm{Cl}^{-}$

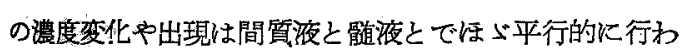
れることから，䯣液と間質液とで恃その由来は異にする

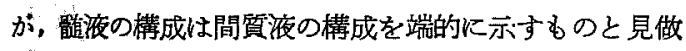
されている. 従つて，血液と骮夜夜又は間質液との平衡成 立の縟僈さは，脳組織と毛細管の間に神経膠細胞の突起 によって形成された血液・脳関門が存在するためである

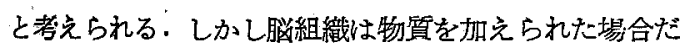
けてなく，正常状態でる二三の無機成分の濃縮と排除を

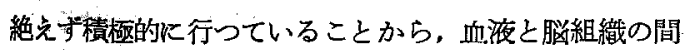

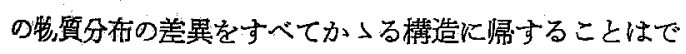

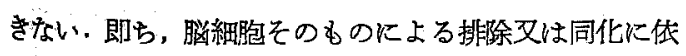
存寸る点る多い之考完られている.

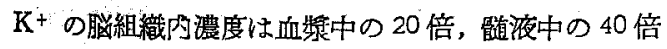
であり， $\mathrm{Na}^{+}$と Cl- は凡と1/3であるが，か子る組

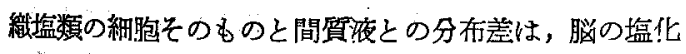

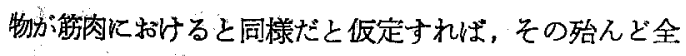

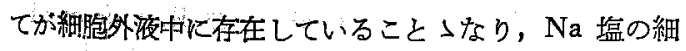

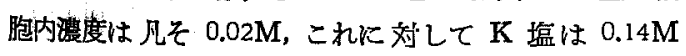
Kなると考觉られる・かくの如く，睬練胞の突起とこれ

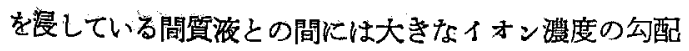

が維持されている(Harrison ${ }^{4)}, 1947$; Manery5), 1952).

in vivoの脳汇含恋孔る単純な無機塩類は血液中比 含まれるむのとは非常に異るが，中枢神経柔内で行われ ている渗透生的過程については，分離脳組㱍を用いた Elliott ${ }^{6)}$, Stern et al ${ }^{\eta}$, Terner et al ${ }^{8)}$, Krebs et a1 ${ }^{9)}$, Aebi 10) 及び Rodnight et al 11) 等の研究があ る.これらの業績を要約すれば，分離組織と $\mathrm{K}$ 塩， $\mathrm{Na}$ 塩との関保仕組織内の活㗶な代謝化依存している。即

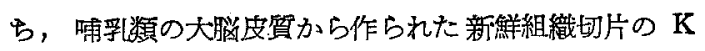
塩濃度は in vivo の脳と同様活 この切片を電孷酸塭溶液 (K 塩浀度は譄を漫している 体夜と注が同じ $5 \mathrm{mM}$ である）に浸し恒温化保つと，

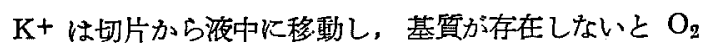
があつてる $38^{\circ} \mathrm{C} て ゙ 1$ 時間後には 80 90\% の K 塩が 組織から失われる。 $\mathrm{O}_{2}$ とブドら精が存在すると，この

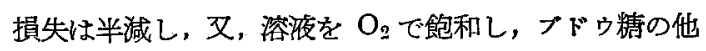
そグルタミン酸を加えると， K 塩の損失は殆えと起ら なくなる.脳組織の $\mathrm{K}+$ 維持にはブドゥ糖の代りに乳 酸や焦性ブド酸を代用することもできるが，いずれに してもブドゥ糖の存在のみ礼らずその代謝が必要であ る・このことは $\mathrm{K}$ 塩の蓄積を阻害する弗化物, ヨード 酩酸，2-4-ジニトロフェノールの作用機序からも判明

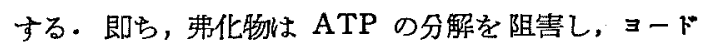
酶酸は燐グリセリンアルデヒド以後の反応を抑制し， 2-4ージニトロフメノールは附燐と酸化の解離を起し，い

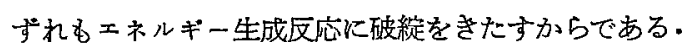

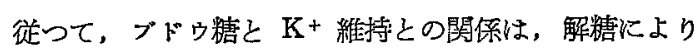
産生されたエネルギーが組織内の $\mathrm{K}$ 塩晨度を高める紷 透压的な過程消消費されると考光られる. 又， $\mathrm{O}_{2}, フ ゙ ト ゙$

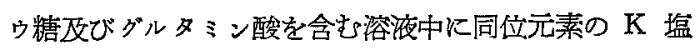
を加光た後，新鮮を組織国片を液内浸し，同位元素を 定量すると媒質液之組織との間で急激な交替が行われ，

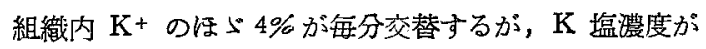
元腹した後子依然气の值を維持するに解糖が必要で ある・高濃度の $\mathrm{K}$ 塩 $(30 \sim 50 \mathrm{mM})$ を加えた含ブドウ

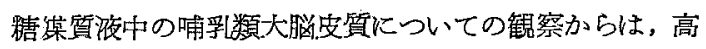
源度の $\mathrm{K}$ 塩により恐らく組峨細胞の脱分極を通じて高 められた呼四と，ブドゥ楉の消費が $60 \mu \mathrm{M} / \mathrm{g} /$ 僻と正常 時の 3 倍に澾し，孚酸形成办 $100 \mu \mathrm{M} / \mathrm{g} /$ 時に文占好気

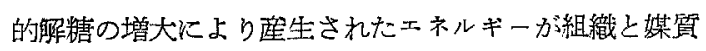
夜との間仁生じた1 ォン勾配の破綻の修得に消費される

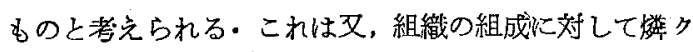
レアチンの減少と無機数酸の增加を伴ら。 
以上の事実より，K 塩， $\mathrm{Na}$ 塩の頸動脈内並びに椎骨 動脈内注入により中枢神経系の呼吸及び好気的解糖の堌 大を招来するものと考党られる。

$\mathrm{CN}$ 化合物： $\mathrm{CN}$ 化合物投与による反応は低酸素状 態の場合と酷似している. Fazekas et al 12)によれば， イメに致死量には至らない量の $\mathrm{NaCN}$ (数 $\mathrm{mg} / \mathrm{kg}$ )を 注射してさ克， $\mathrm{O}_{2}$ の脳動請脈羑は一時的に正常の $1 / 10$ にまで低下し，それと同時に脳呼吸も減少する。致死量 に近い $\mathrm{KCN}(20 \mathrm{mg} / \mathrm{kg})$ では， $\mathrm{O}_{2}$ の脳動静脈差は 18 分以上に亘つて正常值の $10 \%$ 以下にとડ゙まり，1時間 半を経てもな括 50\%に抑制されたを〉回復の兆しを示 さないが，数 $\mathrm{mg} / \mathrm{kg} の \mathrm{CN}$ 化合物では著明な $\mathrm{Hb}$ と の結合は起らないので，この量では $\mathrm{Hb}$ の $\mathrm{O}_{2}$ 運搬能 は正常に維持されている.これは，既に中毒量で $\mathrm{Hb}$ と 綃合する CO と異なる点である。

一方，脳のチトクローム系は $\mathrm{CN}$ 化合物の主要な作 用部位として Himwich ${ }^{13)}$, Albaum et al ${ }^{14)}$ 及び Olsen et al 15) 等に上つて研究されている. Albaum et al に上れば,がイュタネズミに $0.1 \mu \mathrm{M} / \mathrm{g} の \mathrm{NaCN}$ を注射すると，一般に呼吸の增大・興奮・運動失調・痤 戀等が認められ，痤第活動終期の脳標品を分析すると還 元デトクロームC の酸代が正常に比して約 50\%阻害さ れており，呼吸阻簍に伴つて当然予想されることではあ るが，無機燐酸が増え，〜P は減少している. 又無処 置ダイコタネズミの 分離組織に CN 化合物の附加実験 を行うと，in vivoで観察される程度のテトクロ一ム酸 化䤃素の阻霄 $(50 \%)$ は $0.02 \mu \mathrm{M}$ に上つて惹起される ことが判明した． Klein et al 16) のネコを用いた同種 の実験では脳電困が同時汇観察されている．即ち，Na

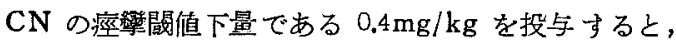
数分に亘つて脳電位の変動が認められるが，この際撛酸 塩には变化がなく，乳酸形成の增大は附加的である。こ の晹合には恐らく解糖が堌大し，正常の脳機能をほが充 分に維持し得るものと思われる・㾏整量の $\mathrm{NaCN}$ は媨

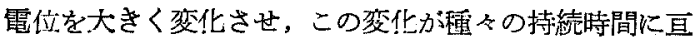
つて進行した後の脳標品を分析すると，燃クレアテンは 減少し， $(0.8 \mathrm{mg} / \mathrm{kg}$ では正常の $24 \%$ 減, $1.2 \mathrm{mg} / \mathrm{kg}$ で

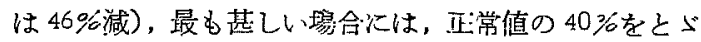
めるに過ぎない. 孚酸 $(08 \mathrm{mg} / \mathrm{kg}$ では正常値の $290 \%$ 增, $1.2 \mathrm{mg} / \mathrm{kg}$ では $195 \%$ 堌) と無機燐酸 $(0.8 \mathrm{mg} / \mathrm{kg}$ で $36 \%$ 増， $1.2 \mathrm{mg} / \mathrm{kg}$ で $57 \%$ 増）の值は高い。

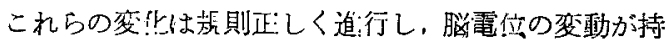
続するに往つて增大するが，脳電位が回復すれば，これ
に伴つて正常値に回復してくる.この回復猧程は爑行過 程よりも遥か以緩慢である・即ち，CN 化台物の投与は チトクローム酸化醉意を阻管するため還元 DPN が り，又，ADP と無機畨酸のエステル化を防ぐが，この いずれす解結を増大させる要因となる。

的上の事実より，CN 化合物の頸動脈内並び椎骨動 脈内注入は脳呼吸の阻害之嫌気的解糖の増大を示す,

低酸素计態：脳代謝の中で最も注目に值するるのは 脳の呼吸である，即ち，脳呼吸が 正常值から 20〜30\% 低下すると中枢神経系の璣能が障碍されると云う点では 大多数の研究者の見解はほぶ一致している。

吸気中の $\mathrm{O}_{2}$ 含有量が $20 \%$ から $10 \%$ に減少してもを トの脳乎吸には認むべき変化は起らない.これは $\mathrm{O}_{2}$ の

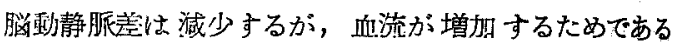
Schmidt 17), 1950). Courtice ${ }^{18)}$ 及ひひ Dumke et al 19）によれば， イヌで $\mathrm{O}_{2}$ 含有量 $7 \%$ 以下の空気を呼詼 させると， $\mathrm{O}_{2}$ の脳動静脈差は常に正常のそれに比して 著しく低下し，又，ほ心゙局程度の が增加し，脳電位が著しく変動するのを锤察している.

低酸絲態による脳代謝変化の最も端的な場合注死後 変化であるが，脳の不安定成分をめぐる協動関保は，死 後数秒間に起ってくる变化の中で既に認められる。即 ち，Kerr 21) に上れば，不安定橉酸が減少すると共化，

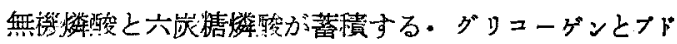
ウ糖注消失し，六炭糖撛雅と乳酸が形成される・この事 実は，脳の固定がたとえ急速に行われたとしても，固定 操作の途上，血流が保たれていないと死後变化同様の変 化が起ることから，死直後の作用因子は恐らく血行停止 であるうと教えられる・かつる死後変化から，正常の䁖 成分は， 〜P を維持しようとするェネルギー産生過屋 と、これを利用しようとするニネルギー消費過程との平 衡议態の䋓果であると考党られる・正常状態に批る主 要なエネルギー座生はブドウ踮の酸化にあるが，緲の $\mathrm{O}_{2}$ 保有量汢どの瞬間に捺いても 10 秒間の消費に相当 する量でしかない.ところで，一度この平衡が破綻する と、ブドウ糖攻びグリコーゲンからの蜼気的琈酸生成と

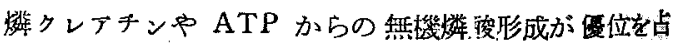
わることつなるが，かつる代謝的变化のうち，とこ新 が中枢役経系内に打污る事態の反映であるかを础定する ことは極めて重要である. Stone29) 及び Richter et al 23）は，これを検索するために被㭘動物に筋肉運動を行 わせたり，又，測这すべき物貿の過剩を血中に注入した 後，その脳内含量の測定を行つたが，その結果，こ১た 


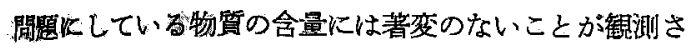
れた.

一方, Gurdjian et al s0)は，イヌに $5 \sim 10 \%$ O. 気 中の叫吸をさせ，故意に低酸素状態に陷入らせて死後変

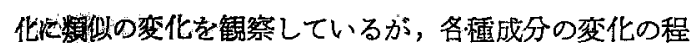
度には興味澡いるのがある。即ち，乳酸（100〜900\% 增) と無譏燐酸 (O〜 125\%増) は增加し，クレアテン燐 酸 (0ん60\%減) は減少するが (ATP は変化なし)，が リシーゲン (-50〜+30\%) とブドウ糖は正常值に上す まる.これれ、，O，の供給が遮断されても，血流がなお 炭水化物を供給するためと考えられる極むて示唆的な事 聿である. 又, 脳 $\mathrm{O}_{2}$ 供給量の正常值は Fazekas et al 24) の成績では $8 \mathrm{ml} / 100 \mathrm{~g} /$ 分で，脳 $\mathrm{O}_{2}$ 消費量 3.3 $\mathrm{ml} / 100 \mathrm{~g} /$ 分の 2.3 倍である. 脳代謝のエネルギー源上 しては，主としてプドゥ糖が問題となるが，脳中の貯蔵 クリンーゲンは約 $2 \mathrm{gr}$ に過ぎず，専ら脳へ供給される 血液中のブドウ糖に依存している. Scheinberg ${ }^{25)}$ の成 頙では，"正常腅のブドゥ糖消費量は $6.2 \mathrm{mg} / 100 \mathrm{~g} /$ 分で， 䑈への供給量の $1 / 10$ を消費するに過ぎない，この供給 '量と消費量との関係より見て, 脳血行障碍の実際は救の 但酸䂆状態として作用することが判る。

以上の索実上り，空気及び油の頸動脈内並びに椎量棋

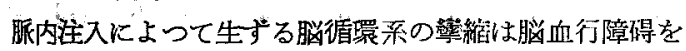
花起するが，この血行障碍の脳代謝に及ぼす影薌は，低 酸素状熊としてら゙あり，CN 化合物と同樣，脳呼吸の低 下と蝐気的解糖の増大を招来するものと考兄られる。

フセキルコリン：Richter et al 26)によれば，脳の ア゙キチルンリン (以下 Ach と略記) 量は, 幼若がイ= クネズミを液体空気中に入れて，脳がに〜4秒で凍絬固 定される上5な方法を用いて分析すると，平均 $7 \mathrm{~m} \mu \mathrm{M} /$ gである・これが，麻酔した動物では8〜10 $\mathrm{m} \mu \mathrm{M} / \mathrm{g} に$

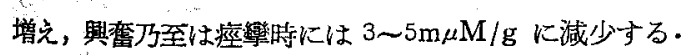
これは恰す，この物質が脳の活動の増加に伴つて消費さ れることを示すかのよらである。

この物質は腅分離組織内では意外にも安宗であり，塭 類溶液中の組織切片や浮游片は注む $10 \mathrm{~m} \mu \mathrm{M} / \mathrm{g}$ の Ach 值类維持する.しかし，これと同媓の Ach を附加して 女加完られた Ach は急速に分解される。そこで，脳本 来の Ach は綰合型であると考えられる。

分離組織ではAch が維持されるのみならず，更に合

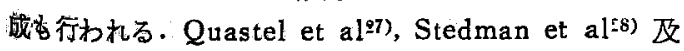

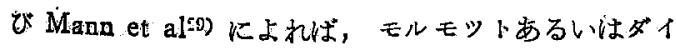

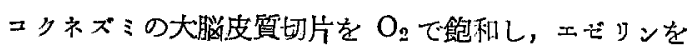
加えた塩類混合液内でブドゥ糖を基質として1洔間呼吸 させると，Ach は初めの $10 \mathrm{~m} \mu \mathrm{M} / \mathrm{g}$ から $50 \mathrm{~m} \mu \mathrm{M} / \mathrm{g}$ にまで増える・脳組織はブドゥ糖・マンノース・乳酸・ 焦性プドウ酸・ダルタミン酸のいずれかを酸化しつ」 Ach を台成する. 従つて，合成に有效な基喟はクレア チン燐酸の維持に役立つ基質と類似している。

合成はかなりの速度で行われるが，正常の眇含量に相 当す五量が10〜15 分かつつて合成される点から云えば， in vitro の合成は in vivo の亟端に速い变化に比して 遥かに緩慢に進行するわけである. 又, 高エネルギー物 顊を消賴する結合型の合成が遊離型よりも遥か心急速に 堌える・切片による Ach の形成は $5 \times 10^{-5} \mathrm{M}$ の Ach 附 加によつて阻害されるが，この理白としては，結合型と 遊離型とが平衡を維持していること, 結:合型は车際には それを合成する酵柔との複合体であることなどが示㥖さ れる.以上の事実によつて，Ach の合成，複合体から の遊離及び水解が無傷の中枢神経系や分離組織の禨能活 性と密接に結びついていることが理解される。

ブドゥ糖の代謝と Ach の合成とは間接的な関係にあ る・即ち、ブドウ糖は解糖を介して高エネルギー物質を 库生し，この高エネルギー物質の一つであるアセテル CoA がコリンと共に Ach の直接的な前駆物質となる わけである. Korkes et al こ0)によれば,コリン， $\mathrm{K}^{+}$, $\mathrm{Mg}$ 及び燐酸イォンを含む反応混合液中では，アセチ ル CoA 0.3mM 溶液の殆んどが ニシンと反応して Ach 老栃成し，同時に等量の CoA ができるが，その反応式 は次の如くである。

$\left(\mathrm{CH}_{3}\right)_{3} \mathrm{~N}+\cdot \mathrm{CH}_{2} \cdot \mathrm{CH}_{2} \mathrm{OH}+\mathrm{CoA} \cdot \mathrm{S} \cdot \mathrm{CO} \cdot \mathrm{CH}_{3}$

$$
\underset{\sim}{\longrightarrow}\left(\mathrm{CH}_{3}\right)_{3} \mathrm{~N}+\cdot \mathrm{CH}_{2} \cdot \mathrm{CH}_{2} \cdot \mathrm{OCO} \cdot \mathrm{CH}_{3}+\mathrm{CoA} \cdot \mathrm{SH}
$$

上の反応で生じた CoA は再びアたチル化されて， 更にコリンをアセチル化するのであらら．睬の Ach 合成率は部位によつて非常に異るが，1般に $1 \mu \mathrm{M} / \mathrm{g} /$ 時 であるこの合成率では，脳組織含量の $8 \sim 12 \mathrm{~m} \mu \mathrm{M} / \mathrm{g}$ が形成されるのに 30〜50秒を要するわけで，中枢神経 系に適用して著明な效果を若起する Ach $の$ 量 ( $1 \mathrm{~m} \mu \mathrm{M})$ は数秒閒で形成されること今なる，このよらに無細胞系 に拈ける合成は，含細胞系におけるそれに比して遥が 速い.

痤筫後の䯑液に Ach が証明されること，Ach の投

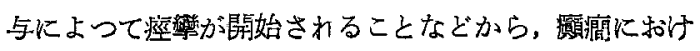


る Ach 代謝の二三の面に研究が進められた. Elliott et al 31), Mc Lennan et al ${ }^{32)}$, Tower et al ${ }^{33)}$ 及び

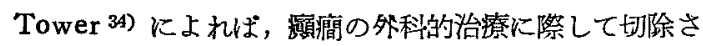
れたヒトの脳組織では常に結合型の库生が低い，又，動 物の大脳皮質にアルミンクリームを適用したり，食䒜に メチオニンスルフォキシドを投与したりして痤得傾向を 誘発することができるが，このよらな組織について検索 された結果，その呼吸と好気的・絣気的解糖は正常であ る・ところが，Ach は同様結合型の形成が低い。これ らの事実は，痤乿とAch の合成態度との間に因果関係 の存在することを暗示する。

Bernheim ${ }^{35)}$, Koelle et al ${ }^{35)}$, Augustinssohn ${ }^{37)}$ 及 び Whittaker ${ }^{38)}$ 等によれば, Ach は鼡組織内で急速 に分解されるが，この消失はAch が単純な水解を受け て、コリンと酶酸に分解するために起るものであつて， コリンアセチラーゼ（ChA）に触媒される反応の逆反 応ではない.この水恽は一群のコリンエステラーゼ (Ch E)によって起り， CoA を必要としない，脳の $\mathrm{ChE}$ の活性值は，脳の部位によつて大きく異なり，各程哺乳 類の全脳について定量された $\mathrm{ChE} の$ 平均値は水珊され るAch に直して 200〜 500 $\mu \mathrm{M} / \mathrm{g} /$ 時である.この活性 值からむ分るように，ChE の活性は脳で行われる急速 な反応過程の一つであるが，その至適活性には注が $3 \times$ 10-3M の Ach の存在が必要である. in vivo の䣼素 作用にとつて重要なことは， $3 \times 10^{-3} \mathrm{M}$ 以下の濃度では 水解率が基質濃度の減少に伴つて低下゙することである。

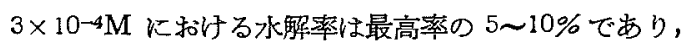
全脳 $\mathrm{Ach}$ 含量の平均値は $10 \mathrm{~m} \mu \mathrm{M} / \mathrm{g}$ で，これは 10-5 $\mathrm{M}$ に相当する，この濃度に拈ける ChE の水解率は， 基質の空適レベルに括ける率の恐らく $1 \%$ を下迴るであ ろう。事契，全脳のAch 水船の最高率である 2 5 $\mu \mathrm{M} / \mathrm{g} /$ 時恃至適濃度下の $200 \sim 500 \mu \mathrm{M} / \mathrm{g} /$ 時の $1 \%$ に当 たる。

Ach 合成に必要なアセチル CoA は，合成される Ach $1 \mathrm{Mol}$ につき $1 \mathrm{Mol} の \mathrm{ATP}$ を消費して作ら れる。哺孚類の脳標品では， $1 \sim 2 \mu \mathrm{M} /$ 混合組織 $\mathrm{g} /$ 時の 率で Ach が形成されるのに対して， 〜P の形成は $\mathrm{O}_{2}$ $60 \sim 150 \mu \mathrm{M} / \mathrm{g} /$ 時の 呼吸率で，2 3M/0 の效率の 時に は 240 900 $\mathrm{M} / \mathrm{g} /$ 時の率で行われる.従つて, ChA が 絶えず最高率で反応するとしても，Ach 代謝には代謝 エネルギーの僅か０.1〜1\%\%を消費するに過ぎない，とこ ろが,この上うに查定すると，Ach の水解率とは相応 しない. ChE は合成時の 100〜 1,000 倍の速度で Achの
水解を触媒し得るからである。しかし乍ら，Ach 隹斯 によるェネルギー消費率を規定するものは，水解てはな く合成である・ところが，ChA によつて極めて短時間 内に合成される程度の量 $(1 \mathrm{~m} \mu \mathrm{M} / \mathrm{g})$ の Ach は痤粠活 動を薊起し，エネルギー生成及び消費を大幅に増大せし むる原因になり得る・そこで，中枢神経秃においてる末 梢神経系と同様, Ach は細胞の接合部户表面でイッ゙ ルスの伝達に関与することができるが，伝澾に和りる Ach の機能を評価するに当つては䋨合型から遊踓型の 活性のAch が放出される速度と逰離型が消費される速 度が極めて重要な問題となる・放出速度は伝䛭開始の速 度を規定し，分解速度は第 2 のヘハバスが伝澾される 前の回復速度を規定するものと考えられる.この放出速 度は分放組織では殆んど研究されていないが，急速なる のと想定される. 分解速度は前述の如く 200 500 $\mu$ M $\mathrm{g} /$ 時で，この速さに達するには Ach が $3 \times 10-3 \mathrm{M}$ の 濃度に存在することが必要であるが，この澧は in vivo の脳平均湢度の 300 倍である. 従つて，Ach の作肺 洔間的, 部位的に高度に局在し得るためには ChE る邓 高度に局在していな汗ればならない。事実, 眇梁は主下 線維から構成されて拈り，シナッブス結合壮少ないか， ChE 値も低い (Feldberg 41) 42), 1945, 1949; Nachm ansohn ${ }^{43}$ ), 1946; Nachmansohn et al ${ }^{44)}, 1951$; Eccles $\left.{ }^{45)}, 1953\right)$.

以上の諸事実より，Ach の大量が 頸動脈並びに櫵骨 動脈内に注入された時には，Ach がインパルス伝羊の 因子々なつて痤挲を始動するが，この際，脱分極を通し て破綻したイオン勾配を修復するために呼吸及び好気的 解糖の堌大を薏起するものと考えられる。

頸動脈立び椎骨動脈内に注入された薬物が中枢神督 系に示寸態度は上述の如くであるが，かつる呼吸と赒諾 の变動がどのようにして機能的活性に結びついているで あろらか?

in vivo ではブドゥ糖が通常 $18 \mu \mathrm{M} / \mathrm{g} /$ 時の㓶飞利用 されて括り，この中， $3 \mu \mathrm{M} / \mathrm{g} /$ 時程度が $6 \mu \mathrm{M} / \mathrm{g} /$ 時の 烰酸に移行しているが, Olsen et al 15)によれば, こ の乳酸の形成は $\mathrm{O}_{2}$ が久泛したり，脳の活動が進与 ると大幅に増大し，短時間に亘つて $490 \mu \mathrm{M} / \mathrm{g}$ /時の高

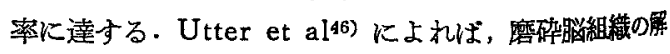
糖を高率に維持するためにはフフドウ䌅以外炕子多くの 成分を加完る必要があるが，六炭糖二燐酸がないと酸か 殆んど形成されないので、これはプドウ糖よりる一首直 接的な乳酸源であるうと考えられる。しかし，持緢肪后 


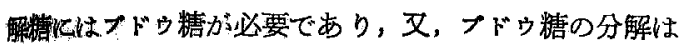
一橉酸老通つて進行する，徒つて，解糖にはATP の如

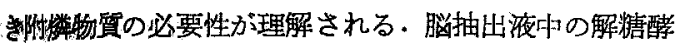
素系俚透析後も残つている. Geiger 47) 及び Ochoa 48) は，むの透析後の抽出液に無機燐酸塩を加えない時には 勫酸は全く産生されないが，この無機燐酸坥か 供給さ れると，解糖に伴つて 燐酸塩がェステル化されると云 う・をのよらに排気的条件の下で多くの〜P の形成が

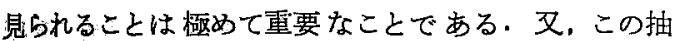
出液中にクレナテンを加えると乳酸の形成が増大し，燐 クレマホンが蓄積する。この事実は，ブドウ糖から始動 される解糖に際して，燐っレアチンが ATPに代り得る ことを示す・ブドゥ糖が乳酸に移行する各過程での燐酸 收支は乳酸と等モルの ATP が ADP と無機燐酸から 生成される勘定になるが, Geiger ${ }^{47)}$ 及び Ochoa48) は この事実を脳抽出液で筧察している・in vivoでは，脳 とそれ以外の部位との間に燐酸交替が砝んど 行われな い、、睬が利用できるアデニンヌタレオチドは約 4 $\mu \mathrm{M} / \mathrm{g}$ であり，無袎燐酸はほ $3 \mu \mathrm{M} / \mathrm{g}$ である。従つ て，ヌクレオチドに変化が起らない限り，解糖が 400 $\mu \mathrm{M} / \mathrm{g} /$ 时で進行すると，利用できる ADP と無機燐酸 は寸べてェステル化されるために反応が制限され，燐 グ リ七リンアルデヒド脱水素酔素，2-燐グリセリン酸フォ スフォキナーゼ及び矬エノール焦性ブドウ酸フォスフォ キナーゼの反応物質は全く消失する.

然し乍ら，解糖経路に含まれる酵素系は，400 $\mu \mathrm{M} / \mathrm{g} /$ 時の速さで乳酸を形成するが, in vivoで䤃素系の能力 がこのよらな最高率に発揮されるのは特殊な場合に限ら れ，正常代謝時には，脳の替在解糖活珄の大部分は活動 していないものと考えられる・この解蓎率を規定する既 知の要因の中で，問題になるのは各解糖過程の反応物質 の㵑度である・この中には，無機燐酸・ADP・ATP・DPN ととの還元型及び各種塩類があるが，この反応物質中，

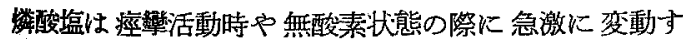
る.これは解糖の反忘物質ともなり，膺生物質こもなつ ている・従って，解糖系は全体として無㙨燐酸值に規定 される.この無機燐酸値を規定する過程の中，酸化的测 橉過程が最も重要である。

Banga et al'9) は八卜脳の透析標品によって，焦性ブ ド酸の酸化には無機燐酸とアデニンヌクレォチドの存 在が重要な閣係をるつことを明らかにした・即ら，この 系の最大酸化は $\mathrm{O}_{2} \quad 120 \mu \mathrm{M} / \mathrm{g} /$ 時の高率に達するが，こ のためには 50mM の無袎燐酸が必要である.この反応
は 1〜10mM の無機燐酸量に対して敏感で方り， 又， アデニンヌクレオチドでは $1.4 \mathrm{mM}$ のアデニール酸，市 るいは $0.35 \mathrm{mM}$ の ATP が最大活脩を与える.

Ochoa (8) は，脳透析標品に弗化ナトリゥムを加觉て， ATP の水解を抑え，クレアチン，ブドッ糖又は六炭糖 一橉酸を加えて燐酸を捕捉し，新らたに生成されたアデ ノシン多橉酸が再び無機橉酸に水解されるのを防ぐよう にすると初めて持続的な附燐が行われることを䚐祭した が,かくて呼吸と〜P エステル形成の関係が明らかにざ れた。

以上，脳の呼吸と解糖について述べてきた点を要約す れば，次の如くである・即ら，in vivo や含細胞腩組織 で行われる炭水化物の代謝を考えると，正常条件下の解 糖と呼吸は大部分連結的な反応である。脳は利用するブ ドゥ糖の $85 \%$ を酸化し，残りの $15 \%$ から乳酸を形成す るに過ぎないところが，解糖と呼吸は交代的に，ある いは平行的に〜P を有生する・ $\mathrm{O}_{2}$ 欠乏のために呼吸が 抑制されると船糖が隻勢になり，非常に異つた量の炭水 化物が消費されるにも拘らず，この二つの系列が産生し

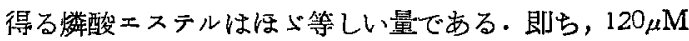
$1 \mathrm{~g} /$ 時の $\mathrm{O}_{2}$ 吸收を示す呼吸は $20 \mu \mathrm{M}$ のブドウ糖から $720 \mu \mathrm{M}$ の〜 $\mathrm{P}$ を生成する.ブドウ糖 $400 \mu \mathrm{M} / \mathrm{g} /$ 侍の解 糖では $800 \mu \mathrm{M}$ の〜P が生成される.ところが，実祭 には血液は脳から過新のブドゥ糖や $\mathrm{O}_{2}$ を搬出するの で，解糖系列も酸化系列も共に自らを制限することいな るが，この二系列には僅か数秒間で脳のすべての無機燐 酸やアデニンヌクレオチドを充分にメステル化する能力 がある.事事は脳の $\mathrm{O}_{2}$ やブドゥ糖の利用率は無機橉酸 や ADP, AMP を再生する反応に依存しているために 制限されている。これらの反応は明瞭に脳の構造維持と 機能に綃びついていることが知られているが，呼吸や解 糖と機能的活性の水準は，主にこの点で結びついてい 万.

従つて呼吸醉素系，解精醉素系が燐酸と燐酸受容体を 必要とすることが脳の構造維持や種々の程度の機能的活 性に必要にして，且充分な〜P を確保するのである。

上に述べてきたよらな畄にお忷る機能的活性と結びつ いた〜P の産生並びに消費過程の大要は, 脳組織を初め 検䒺し得たすべての動物組織を通じて類似のるのである と云う点で研究者の見解が一致している。しからば，脑 とその発生学的系統を同じくする内耳の機能維持にも又 からるェネルギー座生並びに消費過程が結びついている ことは容易に想定されるところである. 


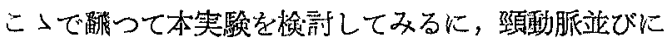

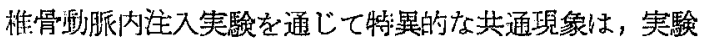
㨽物の一般状態，即ら，全身痤彎とこれに伴う呼吸障碍 とは C.M. 下降と極めて平行的な関係にあることであ る.

ところで, Olsen et al ${ }^{11)}$, Stone et a ${ }^{501}$ 文び Dawson et al 51)によれば, 中枢神絟柔に由来する痤相に 伴つて脳活動が大幅に堌大すると，燐りレアチンとアデ ノシン多燐酸が消失し，無袎燐婹が形成され，又，ブ

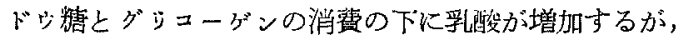

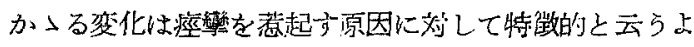

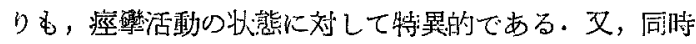

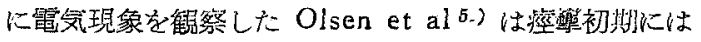

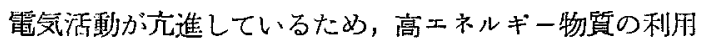
が增大し, 組織の盯蔵物質が大部分消失する。この化学

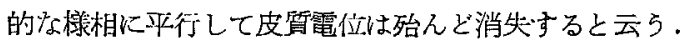

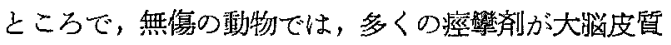
運動領域錐体細胞の 放電頻度を岿明に増加させること は，既に Adrian \& Morzzi ${ }^{53)}$ によつて観祭されてい、 る. 即ち, 雓体細胞は, 四肢の静止封には 5〜50インパ ルス/秒の自発放電を発生しているが，ストリキニン， ベンタメチレンテトラゾール，ピクロトキシン等を作用 させると，1,000 インパルス/秒が 10〜100 インパルスに 相当する短時間出現する。これは，正常には活斯を終熄 させせるらに反応する過程が痤第郕によつて阻害される

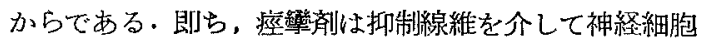

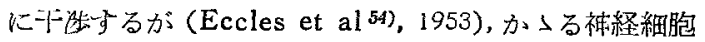
の興慧㕛は折制インパルスの伝遠因子として Ach が作 働する。若し，高度に局在化された部位で $0.1 \mathrm{~m} \mu \mathrm{M} / \mathrm{g}$ の Ach が放任され，至適速度で水解されるとすれば，

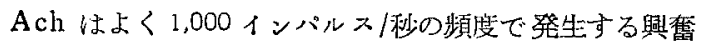

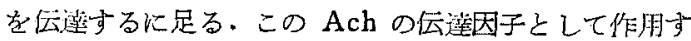
る機棰は来たシ磪諰されていないが, Hokin \& Hokin 55)

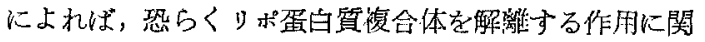
係していると云ら、そこで, 若しこの複合体がシナップ スの緗胞表䤄以 存在するとすれば，Ach がこの部位で 涘の透過性を高める結果，細胞の脱分極が始動され， $\mathrm{K}^{+}, \mathrm{Na}+$ の移動が起つて，膜電位を逆転させるよらな 加向の活唾電位を生ずる。このようにして始䡃された全

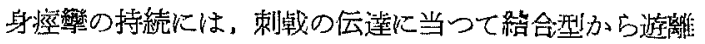
・止解される Ach の合成並びに崩壊せるイォン勾配の

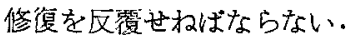

以上の如き多方面但る生化学的事実に立脚して，頸

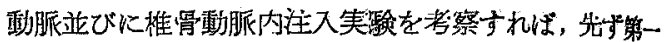

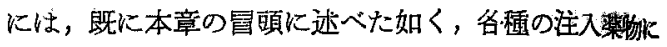

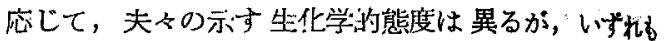

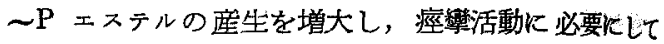
且つ充分なる自由エネルギーを供給するるのと考克られ

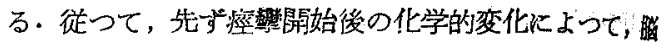
と血液あるいは骮液との物質交換が変動する。即ち，痓

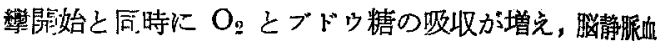
の無機燐酸及び $\mathrm{K}$ 塭が堌加し，Ach，燐酸塩, それK 恐らくはヌクレ水ラ゙ドと蛋白質す髄液中に増加するが， 血中の 中枢神経系と居時に内耳へ移行した薬物によつて，当然 内耳の土ネルキー库生も増大するである5。

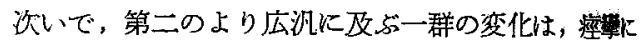
よる無統制な筋肉活動の増大に伴つて起る变化である。

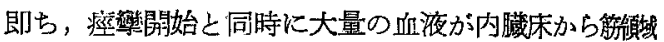
へ移動し，四吸と解糖によるェネルギーの座生と消䨢が

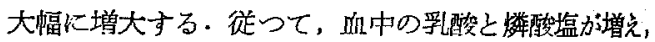
$\mathrm{O}_{2}$ ブドゥ糖が減少する。そこで，本実騟に甜けるが如 く，唯枢神経系の全体㕛は一部が最大の活性を発揮すれ ば，無榴撛酸とアデニン・ヌクレオチドの全眇内含量住 数秒間でェステル化され，エネルギー座生過程は崩㤐

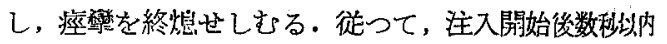

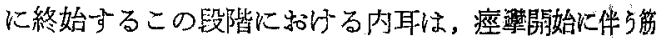
領㣝への緊急且つ大量の衈液移動によつて起る脳血行制 限と更に血中の $\mathrm{O}_{2}$ とブドゥ糖の 低下が反映されるた め，注入楽物による内耳のエネルギー座生増大は橉タレ アテンとダリコーゲンの如き貯蔵物質の動賁下に行る゙れ

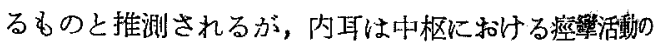

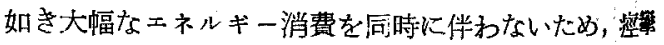

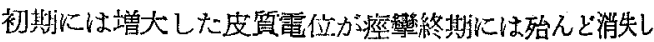
ている(Olsen) のに反てて，C.M. はな蛙充維 されているものと想定される。従つて，この際中枢に姲 けると同樣に内耳にも同時に大幅なェネルギー消費老䓯 起せしされば，例えば，注入と同時に強大音負荷を与え て，薬物により過剩に産生されたェネルナーを急速且つ 大幅に消費せしされば，エネルギー座生過程の崩壤飞伴

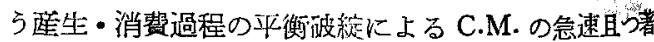
明な低下か諗められるものと推測されるが，私の垁駼心 和いてはその実駼操作上かつる観察をよくためし得怡か つた、今後の研究に俟ちたい所である・又，からる推谢 をもつてすれば，C.M. の恒常性が異常条件に対して至 めて広範围に保たれているという一般的事実，即ら，出 
'凅(日) の内耳血行量と C.M.の関保とか，あるいは Gu-

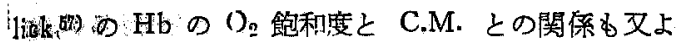
〈理睡でる。.

| 徙つて，本実驗に特行る注入薬物の内耳への直接的影

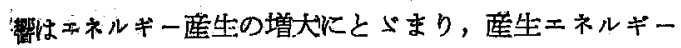
の大幅な゙消費を伴わないため，C.M.の利得は考えられ ても、損失は考光難いが，事契はこの内耳への直接的影 製と同時に中枢性影響が反映するため，私の実験に扣い には、これらの影響を解析することは不可能である・そ にで，この段皆に蛃ける内耳，そのエネルギー産生・ 䏴輩過程の平衡状態を以後の異常条件に対して不安定な

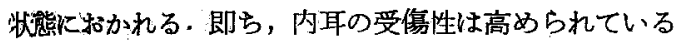
ものと解される。

"“次いで第三の变化は，大脳皮質及び延噵の乎吸中枢刺 笺による呼吸障碍に伴つて起る変化である.即ち，注入薬

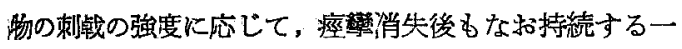
過性の呼吸停止を伴らが，この呼吸停止により,内耳への $\mathrm{O}_{2}$ 供給も遮䉼され，遂にはェネルギー座生過程の崩䔬 沈よる，消費過程との全面的な平衡破綻をきたす。この

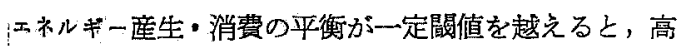
|エネルギー物質の産生低下に平行して C.M. は急速且つ 都明に下降するるのと考えられる。一方，痤第活動時に 性脳のエネルギー友生が大幅に増大するにも拘らず，高 エネルギー物質は正常値より遥かに低下する。従つて，

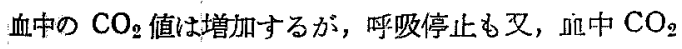
の高値を伴う.この高值の $\mathrm{CO}_{2}$ とよつて，血管の拡張 に上る血流堌加之過呼吸が起り，血中の $\mathrm{O}_{2}$ 值が上昇 し, $\mathrm{CO}_{2}$ 值は低下する。

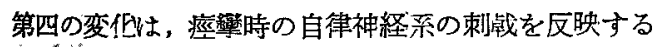
むのである。即ち，血糖山痤彎開始の 1 分以内に上第を 始め，10〜20 分で最高値に達し，静止時の $4.5 \mathrm{mM}$ か ら $7 \mathrm{mM}$ 火増加する。この血糖值上界の外飞副腎刺钱 の徽候として，血圧上昇と既に述べた呼吸の変動が認め られる.

従って, 一過性呼吸停止の後には内耳听行量は增加 じ, 而も血中の $\mathrm{O}_{2}$ とブドウ糖值は上算するが，この段 階においてはなお C.M.は損失過程にあつて，回復は更 に遷延し，緩慢滥過する。

ところで, Stone et al ${ }^{\text {50) }}$ 及び Ruf 5s) によれば， ペンダチレン・テトラン゙ールによつて痤㮍を誘発する と) 動脈血は高い， $\mathrm{O}_{2}$ を維持するが，脳静脈血の $\mathrm{O}_{2}$ と ブドゥ糖とは必ずしも消費し尽されていない，徒って， 胼の呼根は内在的な代謝率によつて制限され，この過剩
な代颜物質の組織内透は抑制され，エネルギー在生基 質として充分利用されない。この事は，勘物に $\mathrm{O}_{2}$ 吸入 を行つたり，又はブドゥ糖を投与したりしても痤挲は延 長するが，痤籍初期よりる高率で呼吸や解糖を行うこと がでさないという事実からも推測される．従って，中枢 神経系の全体又はその一部が最大の活性を発算する短い 活動興奮後の回復過程は活動過程上りも緩|曼に進行す る・例えば, 脳燐クレアチンの相当量が僅かの電気刺㦸 で破壊されるが，その再合成は破壊速度の $1 / 10$ の速度 でしか行われない.ダリコーゲンの回復過程は更に緩慢 である (Dawson \& Richter).

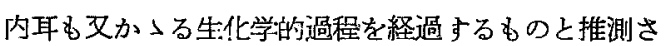
れる. 即ら, 痤㣺並びに呼吸停止による内耳人の基質供

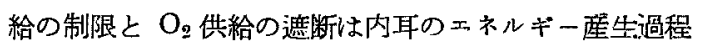
を全面的に崩壊せしめ,すべての無璣獜酸と燐酸受容体 を完全にェステル似するが，これらの再生反応速度は内 耳の解糖と呼吸の進行を制限するため, 血中に過剩に放 出された代謝物筫の内耳組織内渗透は緩慢なる上或過程 を経過するものと考党られる・かつる推測が事実ならば C.M. の回復過程はこの化学的様相之極めて平行的であ り，この事は又内耳もェネルギー㡸生・消費過程の動的 平䱋の上に，その機能を維持していることを示崚するも のである.

以上の考察は，すへて無麻酔の動物より得た資料を元 にしているが，私の実験では麻醉下に行つているので，

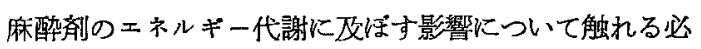
要がある・麻酔や睡眠を荧起する各種の楽物はいずれる 脳成分に類似の変化を及ぼす. 即ち，Stone ${ }^{59)}$ に上れ ば，バルビタール酸誘導体によつてハッカネズミに起る 变化ではクレアチン燐酸と ATP は増え，ダイコクネ ズミでも同様であり (Richter \& Dawson), 又, ェ一 テル (Stone) でる同様である. 従って, 麻醉時の変化 は痙蒘時の逆であり，脳の呼吸は減少するが，高ェネル ギー物質は蓄積する。つまり，麻酢剂によつて脳の高渞 ネルギー物質の消費が抑制されるためと思われる。

以上の事実より，無的醉下で本実駰を行党ば，上り少

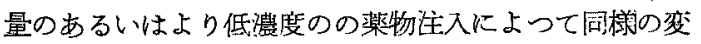
化をもたらし得るものと考兄られる。

\section{第 6 章 結 語}

$\mathrm{K}$ 塩・ $\mathrm{Na}$ 塩, CN 化台物, 空気・油, Ach 等の頸

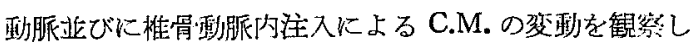
て、次の如き結菕远得た。

1）各程薬物の注入による C.M. 变動の様相は，蒋物 


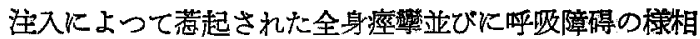
と極めて平行的消長する.

2）各稫藥物注入による C.M. 損失は，内耳エネルキ 一座生・消費過程の動的平衡破綻による．この動的平衡 破綻は痤變並びに 呼吸障碍に伴ら内耳へのブドウ糖と $\mathrm{O}_{2}$ の供給制限あるい慥断によるが，中枢神経系と内 耳はこの点で結ぴついている.
3）各檑薬物の注入により損失Lた C.M. の回復に性

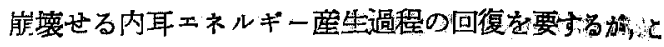
の回復過程の進行は無機橉酸と燐酸受容体の再生速

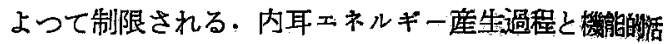
性の水準は主にこの点で結びついている。

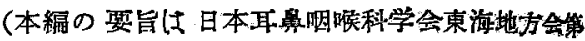
156，158，160回例会で演した).

第 2 編 除脳動物の頸動脈並びに椎骨動脈内注入実験

\section{第 1 章 緒 言}

前編に括いて，中枢神経采の生化学的並びに機能的活 性の変動が内耳機能の低下をきたし得ることを推論した か゚，中枢神経系の各々の機能水準は解剖学的単位を調整 するといらよりはむしろ特殊な機能の統合にあることが 神経生理学の最近の発展から解明されてきた．従つて， 脳の上位の部分は下位の部分に䴔して優位を占め，ひと たび上位の 部分が除去されると，下位の部分が解発さ れ，そのために下位の部分の機能がより詳しく分析的に 解明できるかけである。

私、このような点から中枢機構が内耳機能に这活す機 序索解析する一助之して除脳動物に注入実驗を行つた。

\section{第 2 章 実験方法}

实験動物には 400〜 500g の正常モルモットを使用し， 第 1 編第 2 章記載の実験装置及び方法により C.M.の観 测・記録を行つた。

動物はタロールブロマシンとロレタンの混合麻酥下 に，先ず，頭皮に縱切開を加光，頭蓋骨面を露出し，硬 膜の損傷を避けながら頍蓋を可及的広く開放する．次 に，硬膜に十字切開を入れ，硬脱下に大脳半球あるいは 小脸摘出を行つたが，大脳半球は脳梁部で切除し，大脳 基底核の損傷を避け，又，小脳摘出に際しての脳静脈洞 挰傷には極力留意した．この摘出に際しては除脳硬縮と 一過性の呼吸停止を伴うことがあるが，多くは暫時にし て正常状態に回復する. 又, 出血は,クロールプロマジ ン使用のためかあるい悩血管の収縮性に富むためか比 較的少なく，摘出後間もなく止血することが多いが，摘 出後の全身状態の不安定なもの，出血の多量なもの，あ るいは C.M. 出力の低下したもの等実験条件不良のるの はもとより一切割要し，実䭷の多〈は摘出後 15 分以内 に終了するように努めた。

注入漹物は，脳組織に対して特異的にその生化学的活 性を增大寸ると云われている $\mathrm{KCl}$ と，時間的に局在化
していると云われているアセチルコリンを使用した。斯 く作用部位の比較的はつきりしている楽物を使用したの も解析を容易にするためである.

なお，本害験においては，いずれる頸動脈並び椎骨 動脈内に菜物を注入後直ちに夫々の動脈を結禁した。

\section{第 3 章 実 験成精}

第 1 節 除脳のみの C.M. に及注す影響

除脳動物の頸動脈並びに椎骨動脈内薬物注入実医家施 行するにあたり，先ず除脳の C.M. に及活す影響を钽察 した.その C.M. 変動値を各周波数の平均値をむって表 示すれば第 1 表の如くであり，周波数別变動值を示妆ば 第 2 赟の如くである.

策 1 表 除脳後の C.M. 变㖵值 $(\mathrm{db})$

\begin{tabular}{|c|c|}
\hline 重称者考 & 123 \\
\hline 50 & 0.20 .10 .5 \\
\hline $15 \hat{\lambda}$ & $0.9: 7 / 3$ \\
\hline
\end{tabular}

第 2 表 除脳後の周波数別 C.M. 変動值 (db)

\begin{tabular}{|c|c|c|c|c|}
\hline 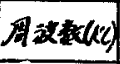 & 0.250 .510 & $2,5 \geq 0$ & 3,0 & 40 \\
\hline $5 \lambda$ & $1,3 \quad 1,0 \quad 0,8$ & $00,3 \cdot 0,5$ & 0 & \\
\hline $15 \widehat{\nabla}$ & $\begin{array}{lll}2.3 & 1.5 & 1.3\end{array}$ & $\cos 3$ & 0.8 & \\
\hline
\end{tabular}

除脳後の C.M. 変動は極めて少なく，いずれるその損 失值は 1〜2db 以内であり，時間の経過を追つてす， 又，周波数別に見ても変動差は極めて少ない.

第 2 節 頸動脈並び椎骨動脈内注入後䋹紮の C.M. 火及ばす影響

頸動脈並びに椎骨動脈肉に $\mathrm{KCl}$ 及び Ach を住风L た後，夫々の動脈を結絷せる場合の成續は既飞前編で述 ベたが，モルモットが夏季汇強く，冬季炕弱いこを性周 
知の事赛であり，季節による全身状態の 変動が C.M. に及活す影響を考え，本実験瑐編の実験とその実施の 季節を異にするので，再度これらの注入実験を行つた。 その成績を各周波数の平均值をむつて一括表示すれば， 第3 表及び第 4 表に示与通りである。

$1 \mathrm{Mol}-\mathrm{KCl} 0.5 \mathrm{ml}$ を頸動脈内に注入した場合注入 30 秘後より低下し始めた C.M.は，2 分後には最大損失值 に達し，その平均値は約 $10 \mathrm{db}$ であるが，4 分後には殆 んと注入前に復元する. 椎骨動脈付に注入した場合に は，頸斯脈内注入の埸合之同様，注入 30 秒後上り低下 し始め，2分後には損失最大となり，15〜20db洼す

第3 表 $1 \mathrm{Mol}-\mathrm{KCl} 0.5 \mathrm{ml}$ の頸動㭽並どに゙推笛動

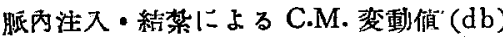

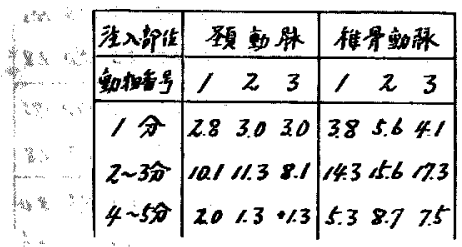

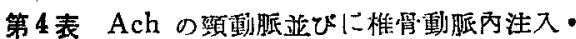
結紮による C.M. 変動值 $(\mathrm{db})$

\begin{tabular}{|c|c|c|c|c|}
\hline 全入却倠 & \multicolumn{2}{|c|}{ 㛚 晾 } & \multicolumn{2}{|c|}{ 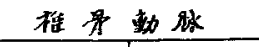 } \\
\hline 注入量 & $3.75 \mathrm{mg}$ & $2.5 \mathrm{mg}$ & $3.75 \mathrm{mg}$ & $2.5 \mathrm{mg}$ \\
\hline 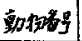 & 123 & 123 & 123 & 12 \\
\hline / 分 & 4.85 .14 .9 & 0.31 .40 .9 & 5.45 .84 .4 & \\
\hline $2 \sim 5 \hat{N}$ & 12.418 .3119 & 4.3 & $352 ; .4$, & 2.86 .99 .3 \\
\hline $3 \sim 5 \hat{\lambda}$ & $1.6 \quad 2.8 / 6$ & 1.1 .31 .8 & $\begin{array}{llll}28 & 38 & 28\end{array}$ & 1.34 .3 \\
\hline
\end{tabular}

るが，回復は遅れて 5 分後にはまだ 6 8db 損失の線 に上がまり，注入前に添隼するのに 10 分間を要する。

Ach $3.75 \mathrm{mg}$ を頸動脈内に注入した場合の C.M.は, 注入 30 秒後上り下降し始め， 3 分後には損失最大とな り，10 20db に達するが，回復は緩漫に 経過し 15 分 を要する. $2.5 \mathrm{mg}$ 注入の埸合には，注入 1 分後に下降 し始め，2分後に最大となり，4〜6dbに達するが，2分 後には汪义回復する.Ach $3.75 \mathrm{mg}$ を椎骨動脈内注 入した場合の C.M.は，注入1分後に低下し始力，4分 後に損失最大となり 15〜20db 飞達するが，回復は緩 慢で10分上上を要する． $2.5 \mathrm{mg}$ 注入の場合には，1分 後に下降し始め，2 分後には最大上なり，その平均損失 値は $6 \mathrm{db}$ で. その後緩慢な回復経過をとる.

以上の成絆は，その变動值及び変動傾向共に前編の実
驗成續上大差なく，文除脳による C.M. 值の变動孔殆 んど認められないので，これらの笑驗を以下に述べる除 脳郵物に和ける注入実験の対照とした。

第 3 節 $1 \mathrm{Mol}-\mathrm{KCl} 0.5 \mathrm{ml}$ 頸動脈的注入笑驗

除脳モルモットに扣败る，1Mol-KCl $0.5 \mathrm{ml}$ の頸動 脈内注入後の C.M. 变秒值を各周波数の平均値をるつて 一括表示すれば第 5 表の如くであり，夫ふの周波数別損 失值を示せば第6 表の通りである。

大脳半球摘出群では，変動が最も少なく 30 秒後に低 下し始めた C.M.は 2 分後には注ら゙回復し，最大損失值 は 8db に及ぶが，一般に損失は 3〜5db である.小脳

第 5 表 除譄後， $1 \mathrm{Mol}-\mathrm{KCl} 0.5 \mathrm{ml}$ 頚動胝內 注入による C.M. 損失值 $(\mathrm{db})$

\begin{tabular}{|c|c|c|c|}
\hline & 大腹樀出 & 小脑鲃出 & 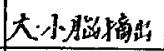 \\
\hline 彭物香节 & 123 & 123 & $/ 23$ \\
\hline $1 \hat{0}$ & $\begin{array}{lll}3.5 & 3.3 & 4.3\end{array}$ & 3.23 .535 & $\begin{array}{lll}3.8 & 5.8 & 6.9\end{array}$ \\
\hline $2 \sim 3 \hat{\pi}$ & $0.40 .2 / .3$ & $1792 \quad 20.719 .0$ & 8.512 .6110 \\
\hline $4-59$ & & 2.32 .8 & $: 02 / .3$ \\
\hline
\end{tabular}

第 6 表 除脑後， $1 \mathrm{Mol}-\mathrm{KCl} 0.5 \mathrm{ml}$ 䜖動胙内注 入による周波数別 C.M. 钼头值 $(\mathrm{db})$

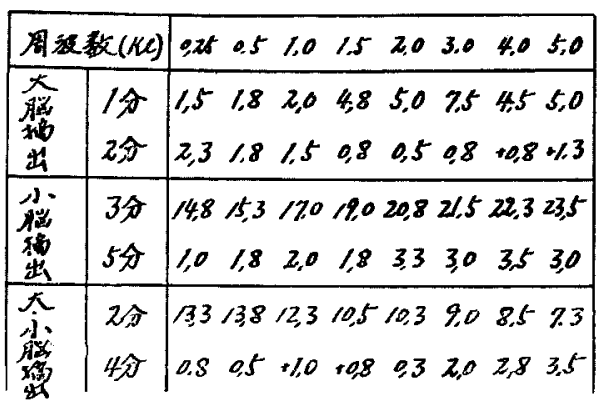

摘出群は C.M. 変動が最も大きく，損失は 30 秒後から 始まり，3分後には最大となり $20 \mathrm{db}$ を越えるが， 5 分 後にはほ心゙回復するも完全には復元せず 2〜3db 損失の 線にとざまる.大脳半珢と小脑とを摘出した群では，対 照群と大羑なく，1 分後に始玉り，2 分後には損失最大 となり $15 \mathrm{db}$ に達するが，平均最大損失値は $10 \mathrm{db}$ で， 4 分後には咶心゙回復する. 以上の备群とも C.M. の变劧 は速やかに経過するため，周波数別損失值の盖異は論じ

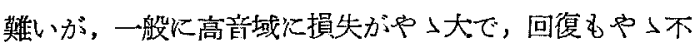
充分な傾向にある。

注入後 C.M. 下降が開始されるまでの時間は，損失 
值の大小に拘らず殆んど变りなく 30 秒〜1 分であるが， 回復過程は損失值の大きい程遅れ，又，損失過程に比乙 て緩慢に経過する。この C.M. 变動経過は，注入によ

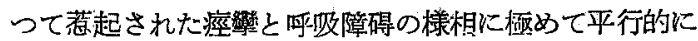
消長するが，痤偝之呼吸障碍は C.M. 下降に先行して， 注入之殆んぞ同時に現れ，又，これらの回復も C.M. 回復に遥加先行する.

第 4 節 $1 \mathrm{Mol}-\mathrm{KCl} 0.5 \mathrm{ml}$ 椎骨動脈内注入実験

除脳後， $1 \mathrm{Mol}-\mathrm{KCl} 0.5 \mathrm{ml}$ の椎学動脈内注入による C.M. 損失值を各周波数の平均値をむつて一括表示すれ ば第 7 表の如くであり，失々の周波数別損失值を示せぜ 第 8 表の通りである. 大脳半球摘出群では，C.M. は注

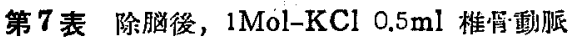
內注入による C.M. 摃尖值 $(\mathrm{db})$

\begin{tabular}{|c|c|c|c|}
\hline & 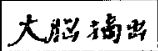 & 小独格至 & 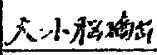 \\
\hline 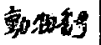 & 23 & 123 & 123 \\
\hline $1 \hat{0}$ & $12.5 \mathrm{l} / 3 / \mathrm{I} / 3$ & $=0.3 \quad 1.20 .6$ & \\
\hline $2 \sim 3$ 分 & & & \\
\hline & & +0.1 & \\
\hline
\end{tabular}

第 8 表 除憏後, $1 \mathrm{Mol}-\mathrm{KCl} 0.5 \mathrm{ml}$ 椎学冓哌內 注入に゙上る周波数别 C.M. 摃火值 (db)

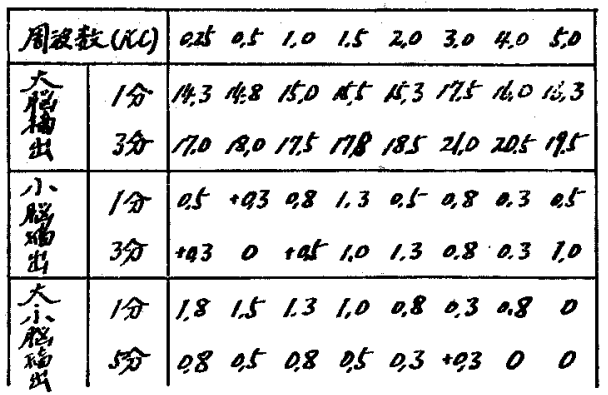

入 30 秒後上り急速且つ著明低下し 15 20db に達し たま〉回復せず，注入開始と殆んぞ同時に痤睦と呼吸嵉 此とが発見するが，引続いて心搏も停止するに至る，小 脳摘出群之大脳半球及び小脳摘出群とは共化 C.M. 变 動も全身状態の变化も全く認められなかった。

第 5 節 アセチルヌリン頸怔脈内注入実験

Ach $0.3 \mathrm{ml}(12.5 \mathrm{mg} / \mathrm{dl})$ 及び $0.2 \mathrm{ml}(12.5 \mathrm{mg} / \mathrm{dl})$ の頸项脈内注入による C.M. の各.周波数の平均强失值 と周波数別䪽失值を一括表示すれば，第 9 及び第 10 表 の如くである。
第 9 表 除脱後，Ach 䫫動脈內注入による C.M. 損夹值 (db)

\begin{tabular}{|c|c|c|c|}
\hline 街入量 & $3,75 \mathrm{mg}$ & \multicolumn{2}{|c|}{$2,5.0$} \\
\hline & 大梅接出 & 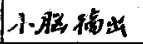 & 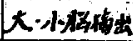 \\
\hline 朝物者是 & 123 & 123 & 123 \\
\hline /命 & 3.92 .72 .5 & 8.28 .310 .4 & $2.73 .5 z .7$ \\
\hline $2-40$ & 11.39 .510 .1 & $16.8 / 14.316 .3$ & $9.6 / 3.9 / 1.5$ \\
\hline $4-15 j$ & $\begin{array}{llll}2.4 & 1.5 & 2.3\end{array}$ & $\begin{array}{lll}1.3 & 28 & 0.3\end{array}$ & 0.30 .80 .7 \\
\hline
\end{tabular}

第 10 表 除脳後，Ach 頸動㭛内注入による '周波数別 C.M. 摃长值 (db)

\begin{tabular}{|c|c|c|c|}
\hline & \multicolumn{2}{|c|}{ 象准数 $(K C)$} & $\begin{array}{lllllllll}0,26 & 0,5 \quad 1,0 & 1,5 & 2.0 & 3.0 & 4.0 & 5.0\end{array}$ \\
\hline $\begin{array}{l}\vdots \\
\dot{t} \\
m \\
m\end{array}$ & $\begin{array}{l}\text { 大 } \\
\text { 独 } \\
\text { 禹 }\end{array}$ & $\begin{array}{l}2 \% \\
40\end{array}$ & $\begin{array}{lllllllll}8.5 & 8.8 & 9.5 & 10.3 & 10.5 & 11.3 & 73.5 & 10.5 \\
2.3 & 2.3 & 1.7 & 1.3 & 1.5 & 2.0 & 2.0 & 1.8\end{array}$ \\
\hline$=$ & $\begin{array}{l}\text { A⿱ } \\
\text { 总 } \\
\text { 出 }\end{array}$ & $\begin{array}{l}40 \\
90\end{array}$ & $\begin{array}{lllllllll}15.0 & 14.3 & 15.5 & 15.5 & 16.5 & 18.0 & 17.0 & 175 \\
7.5 & 1.8 & 1.3 & 1.3 & 0.8 & 1.5 & 1.3 & 1.8\end{array}$ \\
\hline y & $\begin{array}{l}\text { 大 } \\
\text { 惒 } \\
\text { 䊅 }\end{array}$ & $\begin{array}{l}2 \% \\
4 \hat{p}\end{array}$ & $\left|\begin{array}{cccccccc}14.5 & .14 .5 & 13.3 & 13.0 & 13.8 & 8.0 & 8.5 & 8.0 \\
0 & 0.3 & 0.5 & 1.0 & 1.3 & 0.8 & 0 & 1.0\end{array}\right|$ \\
\hline
\end{tabular}

大脳摘是群は対照に比して損失値が少なく，变動経 過与短時閆内に消長し，注入後 1 分後に下降し始的 C.M. は 2 分後には最大となり平均損失檤は $10 \mathrm{db}$ に夜 らかが，4 分後にはほ心゙回復する.

小敛摘出群では，注入 20 秒後に始まる C.M. 下降住

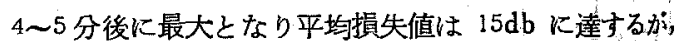
回復にははよ゙10 分を要し，対照に比して損失はや」大， 变動経過は緩漫に消長する・大脳半球及び小㨫摘出群で は1 分後に下降し始め， 2 分後你大となり平均損失值 は10dbを越觉るが，4分後には泀〉回復し，刘然と類 似の損失值及び変動経過を示す。

除脳後の Ach 頸動脈内注入による全身状態を C.M.

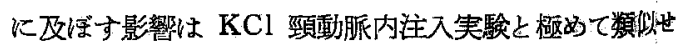
る栐相を示寸。

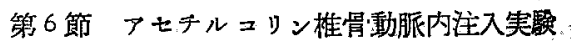

Ach $3.75 \mathrm{mg}$ 及び $2.5 \mathrm{mg}$ の椎骨動脈内注入による各 周波数の平均損失值之周波数別損失值を一括表示寸れ《゙ 第 11 及び第 12 表の如くである.

大悩半球摘出群では，注入 1 分後には未た C.M. 損 失は少なく $3 \mathrm{~d} \mathrm{~b}$ 上内内であるが，1 分 30 秒後上り濑视下 降し始》，5分後には 20db を越光る。この際，注入

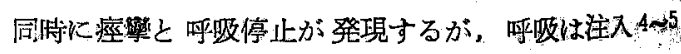


第 11表 除媨後，Ach の椎管重腿內注入に よる C.M. 撌火檤 $(\mathrm{db})$

\begin{tabular}{|c|c|c|c|}
\hline 练入量 & 3. $75 \mathrm{mg}$ & \multicolumn{2}{|c|}{$2.5 \mathrm{mg}$} \\
\hline 8. & 大格垤抎 & 小脱瑻出 & 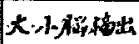 \\
\hline 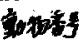 & 123 & 123 & 12 \\
\hline /分 & 0.82 .02 .2 & 3.73 .85 .1 & 79587.4 \\
\hline z & 11799.710 .5 & $13.7 / 3.816 .8$ & $14.8 / 4.0$ 15:5 \\
\hline 4 is & $24: i$ zbo 24.5 & $17.7,8,3$ 28. & 22.819 .8 21.2 \\
\hline
\end{tabular}

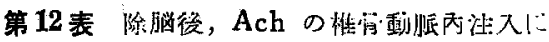
上る周波数别 C.M. 摃头值 $(\mathrm{db})$

\begin{tabular}{|c|c|c|c|}
\hline & \multicolumn{2}{|c|}{ 周波政( $(K c)$} & 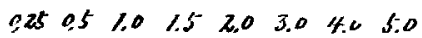 \\
\hline i & 㗏 & $\begin{array}{l}3 \text { 分 } \\
50\end{array}$ & 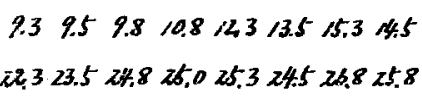 \\
\hline$=$ & 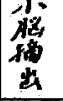 & 3i & 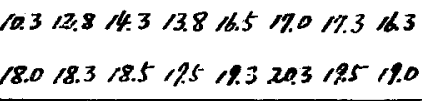 \\
\hline$m$ & 褍 & $\begin{array}{l}2 \hat{0} \\
3 \hat{0}\end{array}$ & 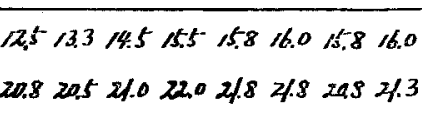 \\
\hline
\end{tabular}

分後に一旦再開されても7〜10分後には呼吸・心搏共に 停止する.

小脳摘时群と大脳半球及び小脳摘出群は共に注入 30 秒得より C.M. 下降か始をり，その後渐次損失を加元， 前者恃 5 分後には $20 \mathrm{db}$ 越え，6〜8 分後には死亡， 後者は 2〜3 分後には $20 \mathrm{db}$ を越え，4～6 分後に死亡す る.

Ach の椎骨動脈内注入笑験でも，注入と同時に痤警 之呼吸停止が萑起されるが，除脳動物では呼吸の回復を 見ずに引続き死亡しているため，夫ょの C.M. 損失差 は满じ難いが，大・小脳摘出>小脳摘出>大脳摘出の順 に損失は急速且つ著明のようである。

\section{第 4 章 総括並びに考按}

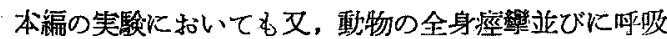
障倡の様相は C.M. 变動の椂相之㥛めて平行的に消失 する・佂つて，先ずこれら全身痤紫と呼吸障碍発現の生 理学的機序を吅心述べる。

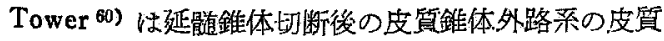
下抑溂伝尊路を追求していた際厄，線状体一淡背球系は 肉包よりる遥加強い 抑制作用のあることを発見した が，文の後 Mettler et al 61) はネニとサルの尾代核に 䉓俅を聥入して刺战すると，この核からは何等の反応む
起らないが，皮質を搉战して誘発させた運動は著明に抑

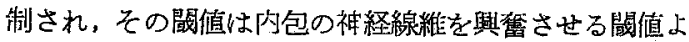
りも低い，又尾状核を予好電気烧枃して括く之抑制俳川 は起らないことを垫め，線状体からの皮質運斬領への抑 制作用に実駼的隻付けを与充た。

Dusser de Barenne et al 62) 63 は大脳皮留の 4 野 と6野の間の狭い帯状の 部位 (4s 野) にストジキン

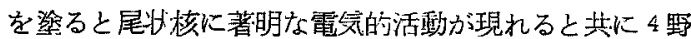
の自軓的電位が抑制され，又 4 野と6 野に入下リテニン を塗つても尾状核には何等の変化も起らず，尾壮核を破 培すると 4s 野からのストリキニンによる抑制が消失す ることを㒛め，皮質と線状体との相互作用を明らか儿几 た。この回路は，4s一線状体－一淡蓄球一視床一 4 野で線 状体淡渞球錐体外路系と云われているものであるが，そ の後この皮質と線壮体の機能の相互作朋が更に明らかと なつた・即ち，Kennard et al (1)(5)によればサルで皮 質の大部分を切除しても脳波にはなんらの変化も起らな

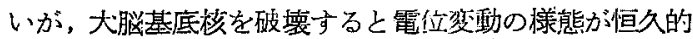

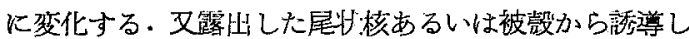
た脳波は皮質を部分町除した埸合と、全切除した塕合とで はその波形が全く異り，皮質との連絡が完全に遮断され た鿟にのみ高電位の脳波が現れた。

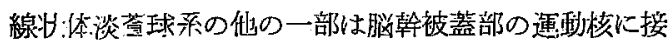

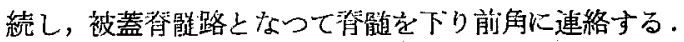

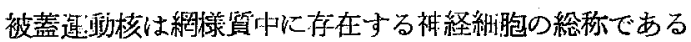

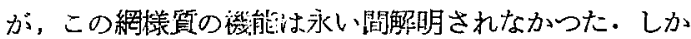
L，1946 年汇至つて Magoun \& Rhines ${ }^{66)}$ は延檤下 部の牌的側に長く延びている網様翼を刺钱すると，脊能道

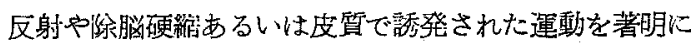
抑制することを発見した・Mc Culloch et al 67) はこ

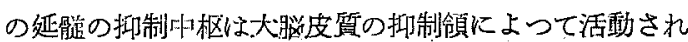
ること，䨤に Nulsen et al (3) は小脳前葉の抑制作朋も 延路網様留を介して起ることを発見した．Rhines \& Magoun ${ }^{60)}$ は束に網様筫のより外側に，上方は被蓋， 中心在白質及び視床腹部にまで起びている促進路のある ことを発見した。この部を刺㦸すると，下位恻枢の反射 を促進し，大脳皮質の刺㦸效果を堌強する・即ち，下位

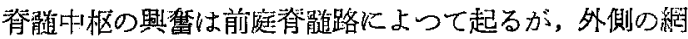
捸質脊髄路によっても促進されるわけである. Ward ${ }^{69}$ は延浗道の抑制中枢に電栖を插入して，正常ではこの抑制 中枢を活動させている大脳皮質中枢が機能を停止した時 飞初めて除脳硬縮の起る過程を $\mathrm{NaCN}$ で上位中枢上り 漸次下位中枢に及ぶ活動抑制の 過程を追求して 薙祭し 
た・かつる状況では促進中枢が抑制を受けずに始動さ れ，春酭の伸張反射が六進し，その結果除脳硬縮が現れ

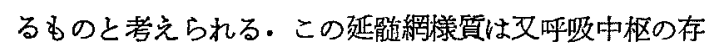
在する部位でもある.Pits et al ${ }^{70)}$ は延䯣呼吸中枢の 位固を確定したが，それによると，吸息中枢はオリーブ 核の直上で腹側網様質の中比較的限局して存在してい ることが解つた。この部位を電気的に刺㦸すると，周期 的な呼吸運動が停止して，胸敦や横瀜膜は最大汲息の状 態でとぶまり，刺戟が長期に亘ると動物は死亡する，呼 息中枢は網樣質の中で吸息中枢のや〉頭方背面にあり， この部位を刺㦸すると呼息運動が起るが，吸息中枢を刺 㦸して起つた吸息運動に比してその程度は弱、ししか

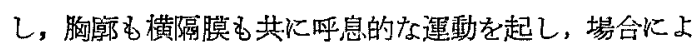
つては最大呼息位をとるが，更に刺战を続彷ると次第に 現れてくる吸息運動によつて動物は死を免れる。呼吸 は文延㭪道よりも更に高位の中枢からも影響を受けてい る・視床下部を刺㥂すると呼吸は抑制されるが，Magoun ${ }^{71)}$ は大脳皮質を切除して数週間を経過したもので視 床下部を刺茂すると，その抑制作用が減弱するのを観然 している.この事実は正常㖩吸が視床下部を通過する大 脳皮質から出る䠌維の 影響を受けていることを示唆す る、そこで呼吸は意識の鮮明度に支配され得る。即ち， 睡眠時あるいは意識障碍時には延㖪呼吸中枢の緊張が低 下し易く，無呼吸移行し易い。

以上の如き全身痤戀並びに呼吸障碍の発現機序の上に 近つて， $\mathrm{KCl}$ 頸動脈内注入笑験を棬察するに当り問題 となるのは内頸動脈の交配領域であるが，尾状核影は前 大脳動脈，尾状核尾之被㲄は中大脳動脈，淡背球は中及 び後大脳動脈支配である.従つて，頸動脈内に注入され た $\mathrm{KCl}$ は下面と後面の一部を除く大脳皮質の大部分と 線状体，淡萛球の大部分に移行して，小脳及び脳幹への 移行は比較的少ないるのと考えられる. 従つて頸動脈よ り脳内へ移行した化学的刺㦸によって落起された與舊は 皮質脊隺路を経て直接に，あるいは皮質錐体外路系より

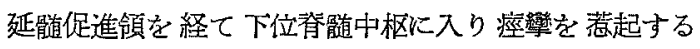
が，前者には皮質抑制領からの直接的扣制が，後者炕は 線状体一淡背球と小脳前葉からの抑制が加わる。この 際, 大脳半球を切除すれば，錐体路采の與鹪伝達は棌断 され，この皮質中枢除去により延䯣促潐中枢は線状体一

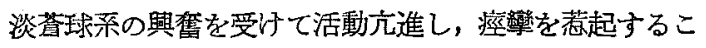
とななるが，小脳からの抑制は免れない，これに小脳除 去を加えると，小㨫からの抑制を受讨ず痤省は更に増強 される、又，小脳のみを除去した場合は，錐体路系・錐

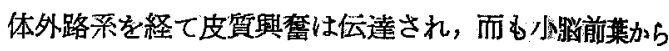

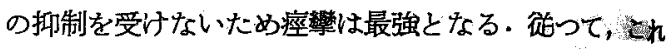

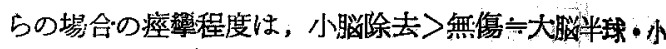
脳除去>大脳半球除去となるすのと考えられる. 一方， 延髄促進中枢に又吸息中枢の存在部位々一致しているの でこのような機序によつて発現する痤戀はその経過に 特いて延䯣吸息中枢をむ刺战して呼吸停止を伴5すのと 推定されるので, 痤㱍程度と呼吸障碍の程度とが恬が平 行する様相は理解できる。この全身痤警並び呼吸障棏

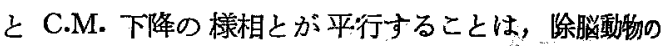
頸動脈内 $\mathrm{KCl}$ 注入に際しての C.M. 下降の支酶的因 子が痤攀あるい呼吸障碍に随伴するものと想定され る.

次に，椎骨動脈内一注入された楽物の多くはその支要 領域から見て当然小脳及び脳幹へ移行し，大部分の大脂 皮質と線状体，谈萛球及び内包への移行は少ないわのと 考えられ，而もこの際の C.M. 下降も痤穒並び呼吸 障碍の様相と平行的である.従つて，こつで先ず取り上 げなければならない問題は，小脳と全身痤攀発現機字と の関保である.

小脳の機能については相対立した二つの考え方があ る・即らその一つは，小脑には小さい筋群関係する性 つきりした局在が存在するといら㗳え方 (Bolk) て， この仮説は現在な赫支持されている.他の考光方は，小 脳は特殊な機能を統御するすのであつて，小脳の個々の 部分がそれに対応する個々の筋を統御するのではないと いら.ところが，小脳の采統発生学や胎生学的な機慛下 関する研究は小脳の機能の一元的概念を支持する方傎 いてはいるが，それにも拘らず，解剖学的局在と恃異る 一種の機能的局在のあることが明らかとなつた，即ち，

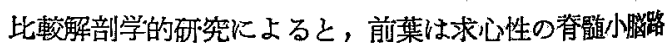
や遠心性の赤核脊喵路によつて姿勢の機序を統御し，邓 片葉小節葉は前庭迷路の機序を統御し，虫部䤮体は隆加

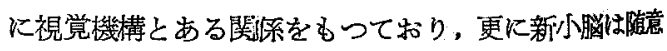
運動の統合作用に関与していることが明らかとなつた。

かくて前葉は高度に分化した機能局在をるつ明らかな 機能的単位であることが漸次解明された. 既て Sherrington は前葉を刺战すると除脳硬縮を抑制することを 見出しているが，Bremer は小悩の抑制作用を再登見 し, 抑制を起す部位恃脊䯣小脳路の線維の終止する部位 であることを指摘した。 Connor ${ }^{72)}$ によれば, 1周の 前葉を完全に除去すると，動物梳小脳全体切除した場 合よりも面に著明な後弓反張となり，陽性支持反店漖 


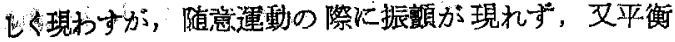
機能の害されないことは極めて重要な事実である。 Snider et al 78) 74) はネこの四肢を刺㦸すると，前葉に

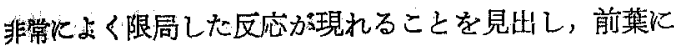
機能局在のあることを初めてはつきりと証明したが，

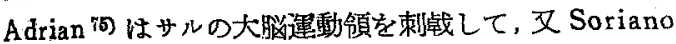
伎ひ Fulton 76) は中心前運動皮質々小脳の種々の部位 を除去する実験を行つて同様なことを証明している・更 にはっきりした証明は Nulsen et al 68) とよつて行わ れたもので，4野の限局した焦点の刺軲仗よつてある筋 と起した收維が小絪前葉の唯一つだけの焦点の刺㦸によ つて抑制されることを見出し，個々の筋群に刘する抑制 焦点を明らかにしたが，更にこれらの研究によつて明ら が炕なつたとは，刺㦸頻度が高い時には大脳皮質で誘

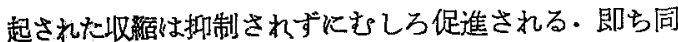
一焦点でも刺㦸頻度によってあるいは抑制されあるいは 促進されるわけで，抑制点る促進点と同一部位にあるこ そななる. そこで Nulsen 68〉は，これら促進と抑制が 同一层導路の刺战頻度によつて起るものか，あるいは二 つの異なる経路があるのかといら疑問に嚆して次の如く 結論した。即ち，歯状核は元来前葉からの抑制就果を伝 澾するもので，室項核は促進效果を伝達するものであ る、更彼等はこれらの效果を脳幹の中まで追求したと

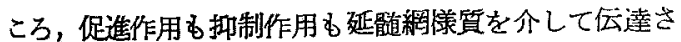
れ，抑制效果は網椂質の抑制領に，又促進效果壮網永質 促進領に至ることが解明された。

以上の諸事害より，椎骨動脈より注入された過剩な化

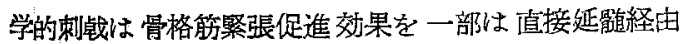
で，又一部は小脳前葉室頂核から延檤網朕質促進領経由

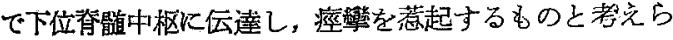
れる。この際，大脳を除去すれば，皮質拁制領からの扸

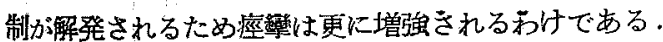
小脳除去の場合は，注入薬物の移行は㱠儿ぞ脳幹に限ら れるので， $\mathrm{KCl}$ の脳幹への影響が問題となるが，脳内 へ移行した $\mathrm{KCl}$ は K- 效果と云わ和る生化学的活性の 增大悉起するものと考克られ，この $\mathrm{K}$ - 效果は睬組 織，而も皮質だけに独自なむのである。徒って，大腷及 び小脳化站して效果的な注入量でる脳幹への影響が少な いこ光は当然考光られ得る.小脳除去，大腷半球小脳 除去の際に，櫵骨動脈内一注入された $\mathrm{KCl}$ により痓䘘 の発現しないのもからる理由によるものと推測される。 又，椎骨動服内注入に際しての興奮伝澾も脊眙促進領を 介するので，同時に吸気中枢を刺战して痤變に伴う呼吸
停止を起するのと推定される。従つて，除脳醇物の椎骨

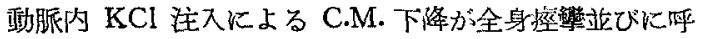
吸障碍の様相と平行的であるという事实から，痤等ある いは呼吸障得が C.M. 下降の直挼的因子を含むものと 想定される。

次に，除脳動物の頸動脈内一アセチルコリン（Ach と略）を注入した埸合は， $\mathrm{KCl}$ の煬合と同様な生理学 的機序によつて 全身痤杽並びに 呼吸障害を伴う。佂つ

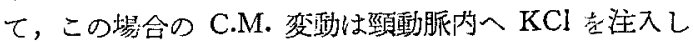
た場合と全く類似の傾向を示す。

所で興䍜伝详の際，Ach が機能的に作衝するために は恐らくは作用点の $1 \sim 2 \mu$ 以内に，従つて細胞周辽の 線維終末に Ach が局在しているものと考光られるが， このAch の作用が時間的, 部位的に局在し得るたぬに は $\mathrm{ChE}$ む文作用点から $1 \mu$ 努けそれ以内に存在してい なければならないわけである.徉って，Ach と ChE は共に白質よりも灰白質に，神経線維よりも神経節之か 核に高度に局在しているが，この局在は脳伙白質に特有 というわけではなく，K一效果の脳皮質に独自であるの とは異なる. Ach を焳骨動脈淤《注入した場合，除脱 動物では注入と同時に呼吸停止をきたし，引続き死亡し ている。従ってこの場合，下降した C.M. の回復は見 られず，椎骨動脈内 $\mathrm{KCl}$ 注入の埸合とは極端にその樣 相を異にする・これは往入により脳幹部へ移行したAch が直接延噵呼吸中枢を刺战し，更に高位中枢である橋， 視床にも影響が及らため呼吸障碍が大となるが，除脳郠力 物では，脳摘出に上り大脳あるい虫小脳の支配血管の収 縮によるAch の脳幹への移行が相対的に增加するため か，あるい恃高位呼吸中枢の存在する大脸皮質の除去 による延喵呼吸中枢の 緊張低下が 前駆しているため， $\mathrm{ChE}$ 不活性化に上る呼吸中枢の不可逆的变化を巷起す るものと考允られる・ところが，Ach の頸動脈内注入 では，延随，橋，視床への移行が比較的少ないためと， 又慆内部位伛よる ChE 局在化により呼吸中枢への刺㦸 も可逆的なるのであろうと溚えられる.即ち，Feldberg et al 75) 及び Burgen et al ${ }^{78)}$ によれば, 眇の ChE の活性值は部位によつて大きく異り，水解される Ach 飞直して大畄皮質が 60 100，小船皮質が 460 ，視床が $270 \sim 310 \mu \mathrm{M} / \mathrm{g} /$ 時であるのに対して，星状核仙怔端に

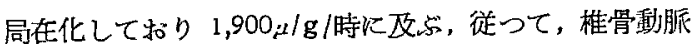
内注入では Ach の不活性化を起す程度の注入量でも， 頸動脈内注入では星状核では至啇速度以下で充分に水解 され得る。従って，KCl 注入の場合と異なり，Achの 
注入では除脳效果が 椎骨動脈内注入の埸合厄著明とな る.

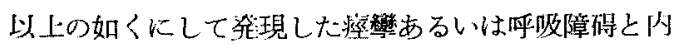

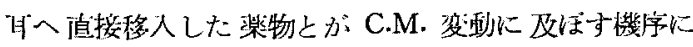
ついては朔編で述べた通りである。

\section{第 5 章 結 語}

除脳モルニシトの頙動脈立びに焳骨動脈们に $\mathrm{KCl}$ 及 び Ach を注入して，C.M. の变動を観祭し，次の結果 を得た。

1） $\mathrm{KCl}$ 及び Ach の頸動脈队注入による C.M. の 損失候向は類似して括り，夫々の損失值は，大脳摘以〉

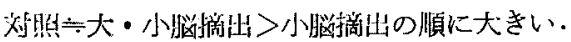

2） $\mathrm{KCl}$ の椎骨動脈内注入による C.M. 損失値は，

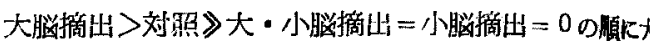
きい.

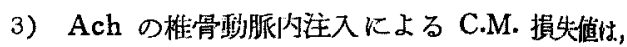

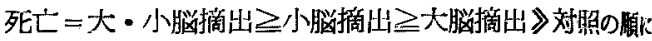
大きい。

4）除悩後の頸動脈並びに椎骨動脈内注入によ。 C.M. の変動様相は， $\mathrm{KCl}$ 及る゙ Ach の部位的飞局在

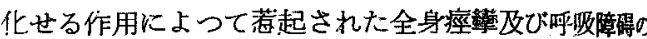
様相と㥛めて平行的に消長する。

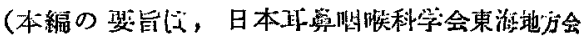
第，161，162 回例会で演した).

第 3 編 大脳度留電気刺载実験

\section{第 1 章 緒 言}

前編までに打いて流血中に注入した各稙輩物による C.M. の変怔を追求したのであるが，その変怔の機序を 解明するためには多くの実験を要する・そこで本編にお いては C.M. に対する中枢性機序の一部を解明:せんと して次の如き実駰を行つた。

\section{第2章 赛験方法}

笑験動物には 400 500g の正常モルモモットを优用し，

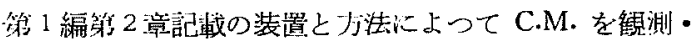
行銢した。がこの際，䏫醉は10\%りレタン水溶液の3 〜5m! を腹空们に注射するにとざかた。理由は，䨑驗 遂行に支障をきたさ和い程度で，可及的少量を伐胜し，

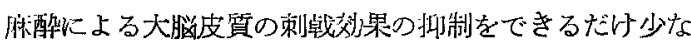
くするためである。

先ず動物を腹位に固定し，頭部に十字四開を加えて頭 蓋を簬出し，刺㦸適用部位に相当寸る頭蓋に開孔し，硬

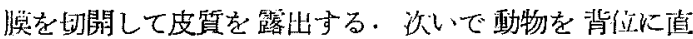

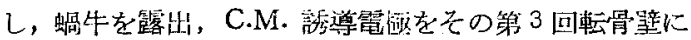

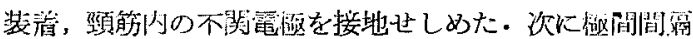
$1 \mathrm{~mm}$, 值堡 $0.1 \mathrm{~mm}$ の双顺電導子を約 $1 \mathrm{~mm}$ 皮質讪に 踭入して，これを碩蓋に固定した。

大脳皮質刺战には，上記双路電遵子を Raymond の 感応コイルの二次側に，一次側には $6 \mathrm{~V}$ の乾䉓他を挼 続し， $12 \mathrm{~cm}$ のコイル間で 60 秒間通電した。

刺戟部位は，ヒトやどんな哺乳珵物の脳でも完企な 分類図は未だできていないので，記載の都合上，一空 Brodmann が主な領野につけた数字に上る名前を用い，

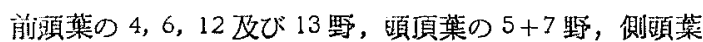

の 20 及び 22 野と後頍葉の 17 野である.

この際，刺战用電尊子の皮質内插入後の测定值を正常

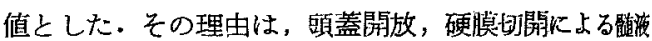
流出，東に，電導子插入に上る皮質損傷等が C.M. . 及汸与影響は極めて少ないとは云え，これらによるC.M. 変㗢が皮質刺战に上る変動に加わることを避けるためて 西り，更に大きな理由は実験操作を容易にするたdで る。

\section{第 3 章 実 験 成}

第 1 節 前䠝葉皮質刺战奏験

前㩆葉各領野の 電気刺㦸による C.M. 变動值を各周 波数の平均值をもつて一括表示与れば第1或及心゙第2装 の如くである.

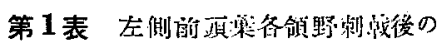

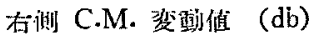

\begin{tabular}{|c|c|c|c|c|c|c|c|c|c|c|c|c|}
\hline 粕 & 部敒 & & 41 & & & $\Psi_{1}^{\prime}$ & & & 2 墅 & & & 398 \\
\hline 亮 & 53 & I & 2 & 3 & 1 & $z$ & 3 & 1 & $z$ & 3 & 1 & 23 \\
\hline 制 & $5 \pi$ & -0.1 & 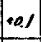 & -1.5 & 102 & 10.4 & -9.5 & -4.0 & $-288=$ & -37 & 125 & 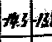 \\
\hline 政 & 108 & $\zeta$ & 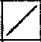 & 1 & -9.8 & -6.3 & -10.9 & -23 & $|+0.6|=$ & -29 & $-4 * 3 \mid$ & $7288-4$ \\
\hline & 15 分 & 0 & $+\infty .6$ & -04 & -5.2 & -5.9 & -49 & -1.0 & $|2 \sqrt{1}|$ & -200 & -174 & $n m \mid n$ \\
\hline
\end{tabular}

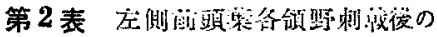

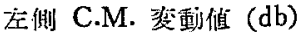

\begin{tabular}{|c|c|c|c|c|c|c|c|c|c|c|c|c|}
\hline 刺虽 & 位位 & & 里 & & & 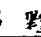 & & & 29 & & & 39 \\
\hline 慗 & 7 番骂 & 1 & $z$ & 3 & I & $z$ & 3 & 1 & 2 & 3 & & 23 \\
\hline 制 & $5 \hat{\lambda}$ & 25 & -3.1 & -22 & 7.7 & -78 & -35 & -35 & -38 & -4.3 & 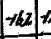 & $321 / y^{2}$ \\
\hline 战 & $10 \hat{\lambda}$ & 7 & & 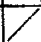 & -60 & 87 & $\mid-21$ & -588 & -5.8 & -50 & -273 & 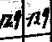 \\
\hline 呅 & 15 分 & $-1 y$ & -17 & -1.9 & -3.1 & $-4,5$ & 10.3 & $-a 8$ & -38 & -35 & 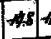 & $\operatorname{dat} \mid \Delta t$ \\
\hline
\end{tabular}


第I表はC.M. 測定側の反刘側を刺㦸した埸合であ ク，第 2 表は C.M. 测定側と同傊を刺㦸した埸合であ る. 即ち，C.M. を刺㦸側で湘定しても；刺㦸の反対側 で測定してもその変動值と，その変動傾问には大差がな i.

而して，皮買刺㦸の反対側及び同側で測定した夫々の 各周波数炕挌ける平均变動值を表示すれば，第了表さり

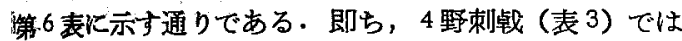
熶大槙失值は $5 \mathrm{db}$ に及方が，全般に損失值は極めて少 なく 0〜3dbである. 6 野刺㦸（表 4)では最大損失值 新 4,000c/s で 15db に達するが, 全般には 6〜7db の 損失を示し，回復後は各周波数間の損失值に大差を認め tsw.

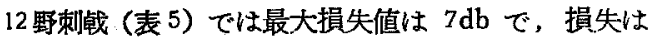

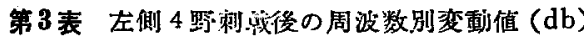

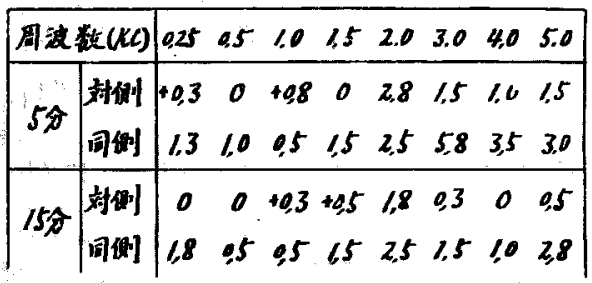

第 4 表，応側 6 野剌战後の周波数別撌火值 $(\mathrm{db})$

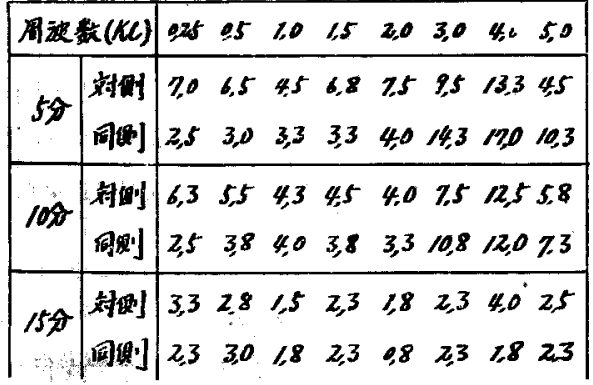

第 5 表 12 野溂战後の周波数别損从佰 $(\mathrm{db})$

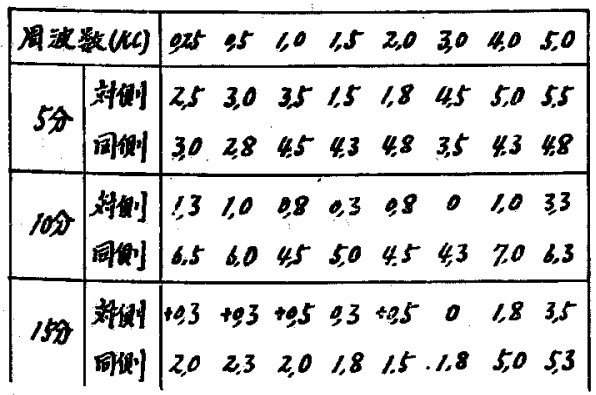

全般に軽度で $5 \mathrm{db}$ 前後であるが，高音域に回復がや〉 不充分な傾向が䍿められる。

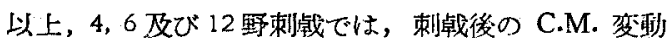
はいずれる可逆的であるが，最も大きい損失值の諮めら れる6野刺㦸では 正常值への 完全なる復元は誌められ

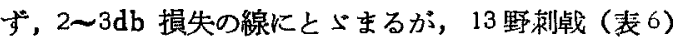
では，刺战後 C.M. 損失は急速且つ著明で，回復の認 められないま〉経過し，その損失値は 15〜20dbであ 乃.

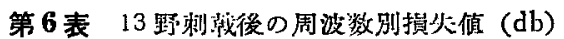

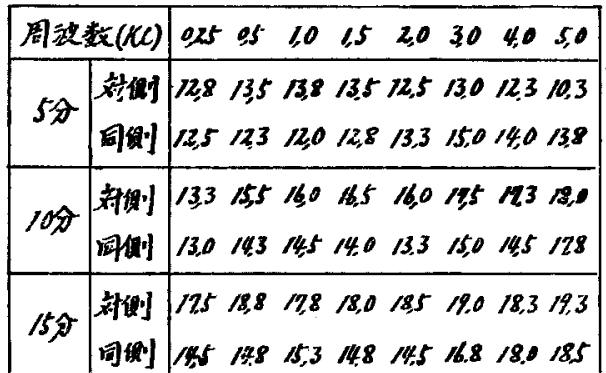

以上の如く，前頍葉刺㦸が C.M. に及洔す影響は各 刺皒領野によって異るが，又，動物の全身壮態に及に゙す

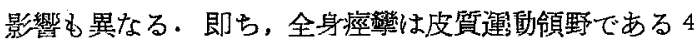
野と 6 野俚勿論，13 野剌战に和いても認められ，更に， 6 野之 13 野の刺战に際しては痤㙰に継起する呼吸の停 止あるいは抑制を伴い，殊に 13 野刺㦸においては著明 且つ決定的である・丞鲑及び呼吸障碍は一般に刺㦸開始

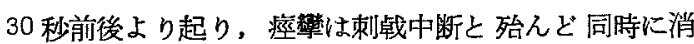
失するが，呼吸障碍は刺㦸中断後も持続 $\mathrm{L} ， 6$ 野の刺㦸

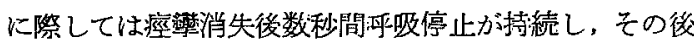
過呼吸状熊を経て 5 分以内に（多くは2〜3 分後には）

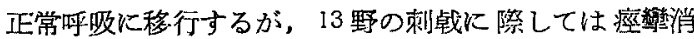
失後数秒間に亘つて停止した呼吸は，その後殆んど過呼 吸状熊を経ずに頻数・微弱となり，洀次その数を減じて 回復の兆しを示さないま〉多くは数時間後に死亡する。 このよらに6野上 13 野刺战後に 発現する呼吸障得の経 過と C.M. 変動の経過が平行的である点と，更に皮貿 刺㦸の反対側で測定しても，同側で測定しても，C.M. の变動值と变動傾问に大裳が認められない点から推测す れば，大脸皮質の電気刺影が哦吸障碍，即ち， $\mathrm{O}_{2}$ 欠乏 として队取に反映され，C.M. に影響を及便し得万可能 性は否定できない。 
第 2 節 頭頂葉皮質刺战实験

碩頂葉では， $5+7$ 野の刺㦸実験を行つたが，その成 維を各周汥数の平均值をむつて表示すれば第 7 表の如く であり，皮質刺战の反対側及び同側で測定した各周波数 における平均損失值を表示すれば第 8 表に示す通りです る.即ち， $5+7$ 野の刺战では，剌㦸反対值の C.M. 損 失がー般に大きいが，いずれも可逆的である。たよ， $4,000 \mathrm{c} / \mathrm{s}$ に和ける回復加不充分である。この5+7野刺

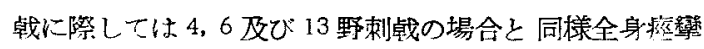

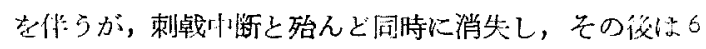
野と13 野刺㦸に際して認められたよらな呼吸障碍は認 ओなw.

第 7 表 左僋 $5+7$ 野刺战㣪 0 C.M. 損火值 $(\mathrm{db})$

\begin{tabular}{|c|c|c|c|c|c|c|c|}
\hline & & \multicolumn{3}{|c|}{ 刺壐姆侧 } & \multicolumn{3}{|c|}{ 籼赫侧 } \\
\hline \multicolumn{2}{|c|}{ 新物番号 } & 1 & 2 & 3 & I & 2 & 3 \\
\hline \multirow{3}{*}{$\begin{array}{l}\text { 利 } \\
\text { 战 } \\
\text { 㣞 }\end{array}$} & 5 分 & 7.8 & $/ 6.3$ & 132 & 8.2 & 7.3 & 8.3 \\
\hline & 10 东 & 2.2 & 8.4 & 4.6 & 89 & 178 & 105 \\
\hline & $15 \hat{7}$ & 24 & 6.1 & 1.3 & 2.8 & 9.1 & 1.3 \\
\hline
\end{tabular}

第 8 表 左側 $5+7$ 野刺战後の周波数別損头值 $(\mathrm{db})$

\begin{tabular}{|c|c|c|c|c|c|c|c|}
\hline \multicolumn{2}{|c|}{ 周波融( } & 025 0,5 & 1,0 & $1,5 \quad 2,0$ & 3.0 & 40 & 5.0 \\
\hline \multirow{2}{*}{$5 \hat{\jmath}$} & 刘侧 & $.0,514,014$ & & 745148 &, 443 & 175 & 16.5 \\
\hline & 周倒 & 60758 & 83 & $28: 83$ & 88 & 8,0 & 80 \\
\hline \multirow{2}{*}{$10 \hat{0}$} & 婎了 & $1,5 \quad 1,8 \quad 3$ & 3,0 & $4,0 \quad 5,3$ & 6,8 & 10,3 & 3,5 \\
\hline & 同䬳 & $8,3 \quad 8,58$ & 8,0 & $70 \quad 7,3$ & 10,3 & $\mu, 0$ & 15,0 \\
\hline \multirow{2}{*}{$15 \hat{\lambda}$} & 対侧! & $1,8 \quad 2,0$ & 1,5 & $1,8 \quad 2,5$ & 4,8 & 11,0 & 2,8 \\
\hline & 同借 & $28 \quad 353$ & 3,3 & $3,8 \quad 4,0$ & 6,5 & $-15,5$ & 6.0 \\
\hline
\end{tabular}

第3 節 側頍葉皮質刺㦸夷験

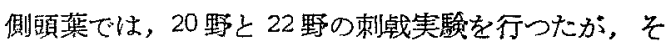
の成績を各周波数の平均值をむつて一括表示すれば第 9 表の如くであり，皮层刺㦸の反対側及び同側で測定した

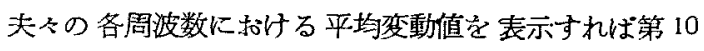
表と第 11 裴に示り通りである。

即ち，20野の刺践では殆んど変動が梁められないが， 22 野の枮㦸では一般に 6〜8db の C.M. 賣失を示し, 可逆的に経過与るが，高音域の回復は迤延する傾向にあ

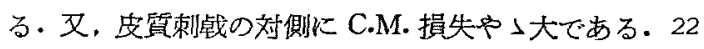
野の刺战に際しては，支質運動領刺㦸の場合と同様，雇

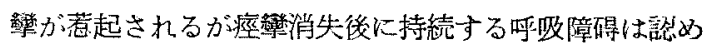

第 9 表 左側 20 野及び 22 野剌僦後の C.M. 婪動偪 (db)

\begin{tabular}{|c|c|c|c|c|c|c|c|c|c|c|c|c|c|}
\hline & & \multicolumn{6}{|c|}{ 刺封侧 } & \multicolumn{6}{|c|}{ 制成㒋 } \\
\hline \multicolumn{2}{|c|}{ 籼成却位 } & \multicolumn{3}{|c|}{20 野 } & \multicolumn{3}{|c|}{$2 z{ }^{9}$} & \multicolumn{3}{|c|}{$20 x_{j}$} & \multicolumn{3}{|c|}{$2 \pi 3$} \\
\hline \multicolumn{2}{|c|}{ 動物看骂 } & I & $z$ & 3 & ' & 2 & 3 & 1 & 2 & 3 & & 2 & 3 \\
\hline \multirow{3}{*}{$\begin{array}{l}\text { 划 } \\
\text { 甜 } \\
\text { 接 }\end{array}$} & $5 \pi$ & $\mid a q$ & -98 & -1.9 & 8.2 & -83 & -8.3 & -3.1 & -28 & -51 & $8, \pi$ & & 54 \\
\hline & 10 分 & .04 & -.03 & 28 & -5.6 & $-4 \div 0$ & -27 & -25 & 125 & -42 & -45 & -44 & -33 \\
\hline & 158 & $t / 4$ & -1.6 & $-\infty x$ & 4.0 & $-4: 0$ & -37 & -8 & +18 & $x .8$ & -15 & 12 & af \\
\hline
\end{tabular}

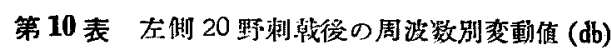

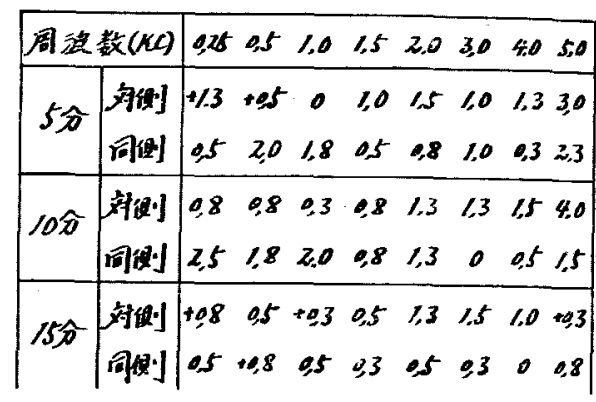

第 11 表 左㒋 22 野刺戴後の周波数別揣火值 (db)

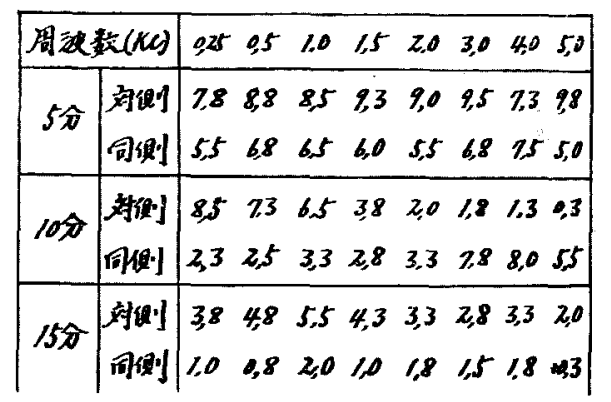

られない。

第 4 節 後頭葉皮質刺戱実験

後頭葉では，視覚領である 17 野の刺战実験を行わた。

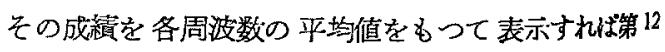
表の如くであり，皮質刺战の反対側及び同側で測定した 夫なの各周波数における平均損失を示せば第13 表の通 りである。

第 12 表 左側 17 野刺㣀後の C.M. 摃失值 (db)

\begin{tabular}{|c|c|c|c|c|c|c|c|}
\hline & & \multicolumn{3}{|c|}{ 籼䣡胡州 } & \multicolumn{3}{|c|}{ 㮃较观 } \\
\hline \multicolumn{2}{|c|}{ 立特者与 } & $i$ & 2 & 3 & 1 & 2 & 3 \\
\hline \multirow{2}{*}{$\begin{array}{l}\text { 刺 } \\
\text { 然 } \\
\text { 後 }\end{array}$} & $5 \pi$ & 28 & 0.5 & 22 & 20 & 25 & 1.6 \\
\hline & $15 \pi$ & 1.7 & 1.3 & 1.3 & 43 & 18 & tod \\
\hline
\end{tabular}


第 13 表左側 17 野刺战後の周波数別損头值 (db)

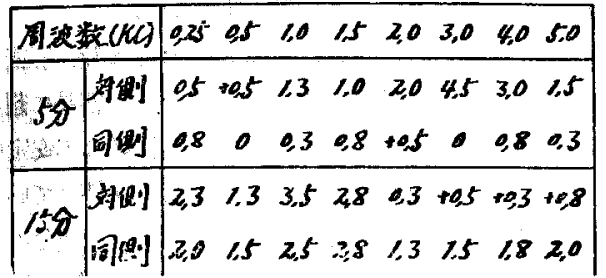

即ら，C.M. 損失は皮質刺㦸の㸚側，同側を問わず， 及，各周波数別にも大差なく，5db を越えない，17 野刺 战では，前節で述べた聴覚領である 20 野刺㦸の際と同

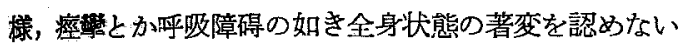
が, 側頍葉の 22 野と頍頂葉の $5+7$ 野の刺战では痤繁が 発現すると共に C.M. にもかなりの変動が諗められる

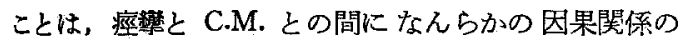
存在することを暗示する・

\section{第4章 維括並びに考按}

生椺力゙機能的活性を維持するためには，血行によって 供給される基質の不断の代謝が必要であることは論を侯 たない。

ところで，Gibbs et al ‘9)によれば，各種物質の脳

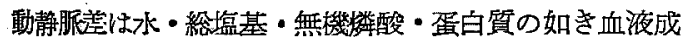
分火は变化がないが， $\mathrm{O}_{2}$ 含有量は $6.7 \mathrm{ml} \%$ の低下を示 し，これに伴う $\mathrm{CO}_{2}$ の変化は $6.6 \mathrm{ml} \%$ である. 即ち， 正常媨の呼吸商は殆んど1に等しいことになる，徉つ て，血液成分中脳内で酸化される主要物質がブドゥ糖で あることは容易に想定されるが，Fazekas et al 24) に よれば，脳 $\mathrm{O}_{2}$ 消費量は供給触の 1/2.3であるのに詨し， 睬ブドゥ糖消費量は供給量の1/10 K過ぎない（Schei-nberg et al 25)).この供給量と消費量の関係より見て, 脳血行制限は脳 $\mathrm{O}_{2}$ 欠乏として作用することが窥兑る。 か」る事実から内耳を類推し得るならば，その機能的活 珄を維持するに必須な物質はブドウ糖と $\mathrm{O}_{2}$ でありこ の機能維持を左右する一義的因子は $\mathrm{O}_{2}$, 換言すれば内 耳血行であると考党られる．他方，この内耳機能に刘す る $\mathrm{O}_{2}$ あるいは血行の重要性については，既に Bornschein et al ${ }^{80)}$, Wever et al ${ }^{81}$ ), Gisselson ${ }^{82)}$,豊島 ${ }^{83}$, 安達 ${ }^{81)}$, Tonndorf et al ${ }^{85)}$, 丸山( ${ }^{56)}$, Fernandez ${ }^{86)}$,

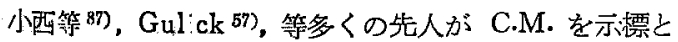
して強調して括り，又，Lawrence \&.Wever ${ }^{88)}$ は $\mathrm{O}_{2}$ 欠乏により, Kimura ${ }^{89}$ は inferior cochlear vein とその副血行路の障碍により，いずれも内耳に組織学的 異常所見を確認している.
往つて，大脳皮質と内耳機能との閊連を論ずるには， 先ず，大脳皮質が内耳血行を機制し得るや否や，機制し 得るとすれば，いかなる機序によつて，どのように機制 するかについて論ずべきであろらが，物質代謝に結びつ いた内耳機能を理解するには，発生学的系統を同じくす る中枢神経系の機能活性に繁嘧に結びついたェネルギー 代謝系の諸知見から有力な手がつりが得られるものと考 え，電気刺㦸に対する脳組織の生化学的態度の検討から 考按を進めてみよ 5 .

艒組織については; 従来全魚やカェルを用いて各種の 研究が行われてきた.即ち，Libet et al 到はカェルの 脳を注意潹く分渢すると，その嗅球は in vivoのそれ に類似の律動的な放電を，短時間ではあるが，維持し， 更に，この放電のパターンが範気刺㦸に応じて変化する と共に，呼吸にも変動の及ふことを観察している・しか し Burns 91) 92)によれば，哺乳類の脳では，これを摘 出すれば，たとえ組織学的な変北は起つていなくとも， 既に，その活動電位は全く消失しているという.この事 実から哺乳類の脳は血行による一磳多くの，一層持続的 な物筫洨換を必要とするるのと考えられる，征つて，分 離脳組織では，もとより in vivo の皮質電図に相当す る自発放電は認められないが，電気刺㦸を加えると，そ れに応じて，脳組織細胞の静止膜電位が变動する。

そこで, in vivo で刺㦸に応する電気的活性と代謝勇 の变化との相互関係を分析的に検索することは極めて困 難であるので, in vitroでこれらの実験を行いながら， 生体内での機能と代謝との関倭を類推しようといら試み が Mc Ilwain et al 93) 94) によつて企図されたのb当 然と云わねばならない。

分韵脳組織の乎吸は，たとえ附加基質が無くとも起 り， $\mathrm{CO}_{2}$ す文明らかに内在基質から放出されるが，か $\checkmark$ る内在呼吸は時間の 経過と共に著しく低下し， $37^{\circ} \mathrm{C}$ で反灾時間後には初めの值のほよ゙1/3となる・ブドウ梼 はこの低下をよく防ぐが，更にブドゥ桾を奏䋡の当初よ り加えて置けば，数時閒に亘つて遥かに高く，又安定し

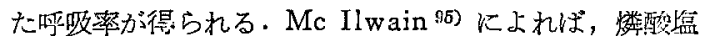

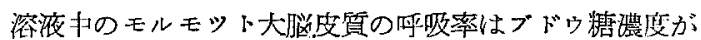
OnM から 1 1.5mM（約 20〜30 $\mathrm{mg} \%$ ） に增加与る

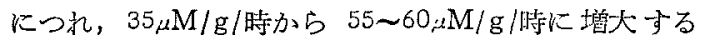
が，これ以上の高濃度では，なと文 $10 \mathrm{mM}$ に增加して も，乎吸率には殆んど变化がない 組織呼吸の、ブドウ 糖濃度に対するこのよ5な依存性は組織から電気的に刺㦸 されると一尿明瞭となる・即ち，ブドウ糖濃度が $0 \mathrm{mM}$ 


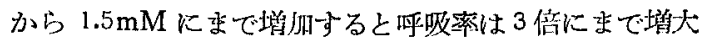

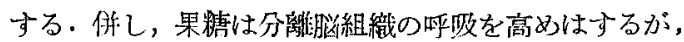
ブドゥ糖と同程度の效果を発揖するには10倍量が必要 である。文，in vivoの脳には果糖がある限定された量 しか到達しない。

これらの雪実がら，果糖は，in vitroでブドウ糖の 代りになり得ないし，又，in vivoでもブドウ糖の代り にはなり得ないと考亮られる・併し，カルボン酸の中で は乳酸と焦性プドゥ酸は共に in vivo の脳でも，及， 分離組織でもプドゥ糖から産生されるが，適当な濃度に 与えられつば酸化基啠ともなり得る。従つて, in vivo で脳の乎吸を支える物筫は，ブドウ糖とその産生物であ る乳酸と焦性ブドゥ亚限られる (Mc Ilwain).

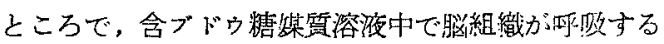
と液中に乳酸が蓄積するが Mc Ilwain 20゙によれば， 電気刺㦸によつて 乳醮形成は2〜10倍に堌大する。即 ら，モルモット及はウサギの大悩皮質を $10 \mathrm{mM}$ の含ブ ドウ糖重炭酸塩溶液中に浸すと $100 \mu \mathrm{M} / \mathrm{g} /$ 時の乳酸 仅成率が１時間以上に亘つて維持されるが，剌㦸を 中断すると解梼は1分又はとれ以内に刺㦸前の值に復 元する・ところが, in vitro 電気刺战では in vivo

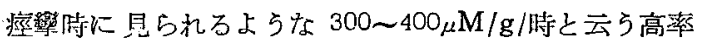
に達することはない。かつる高率は細泡內のブドウ糖ま

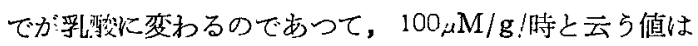
細胞内ではなく密ろ細胞外ブげウ糖の解楉率を意味する

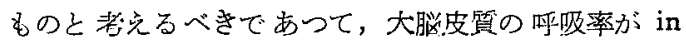
vivoでは $120 \mu \mathrm{M} / \mathrm{g} /$ 㭙, in vitro では $55 \mu \mathrm{M} / \mathrm{g} /$ 作で

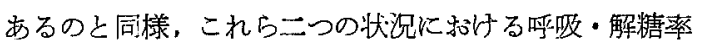

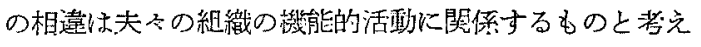
られる・即ら，分離組織では僟能的活性を伴るないが故 に，その呼吸・解糖率が低いと若えられ，この率笑は 文，呼吸及び解糖と機能的活性の密接なる関係の存在を 示㗪するむのである。

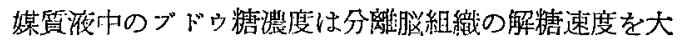

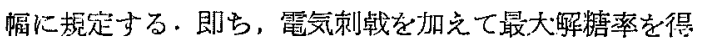

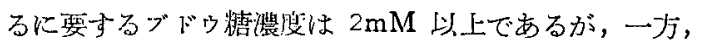

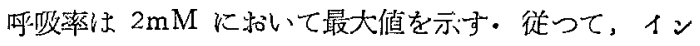
シュリン低血桾脚に向精值が $2 \mathrm{mM}$ に低下しているに

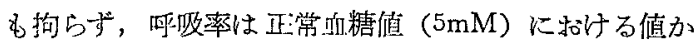
ら㱠えど焦下゙していないのは，至適以下の解糖が行われ ているためと考えられ（Mc Ilwain）この事笑は，呼 四によつては維持され得ない脳の機能的活性を解糖が維 持し得ることを暗示寸るが，この事は又， $\mathrm{O}_{2}$ の重要性

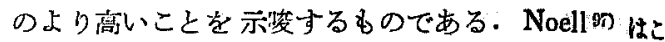

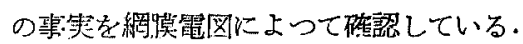

以上の如く，電気刺㦸による，脳の呼吸及び解精の増 大に伴い，穖能的活性が強調されることは容易火想定さ れるが, in vivoの仍究によれば，脳組織の不安定成分 の量は代謝と機能活性により密接な関係を持つている. しからば，電気刺㦸によつて組䅧内の不安定成分の量的 㚆動はいかなる経過を巡るのであろらか？Mc Ilwain 93), Head et al (8), Head (9) は, in vivo の㨫組緎, 及び組織標品作製中と標品に電気刺㦸を加える前，加え

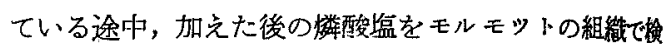
索しているが，それによると，ATP の分解は刺㦸影始

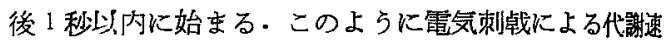

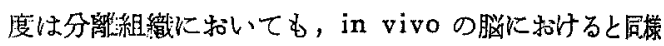
極端に速いが，併し ATP の分解は全体量の1/3以上 には及妨ない，即ち，剌战前 $2 \mu \mathrm{M} / \mathrm{g}$ であつた ATP は束战開始 I 秒後には $1.4 \mu \mathrm{M} / \mathrm{g}, 2$ 秒後には $1.3 \mu \mathrm{M} / \mathrm{g}$ と低下したものが，3 秒後には $2.1 \mu \mathrm{M} / \mathrm{g} /$ 時と回復して いる(刺㦸は 10 秒間適用)・一方，燐クレアチンは，刺 㦸の初めの 1〜2秒力゙経過すると低下し始め, これに伴 つて ATP は堌加するが，この燐クレアチンは 0.4 $0.5 \mu \mathrm{M} / \mathrm{g} /$ 秒（略 $1,500, \mu \mathrm{M} / \mathrm{g} /$ 時）と云万極端な速さて， 凡そ4秒に亘つて低下゙し続け，その後低い定常値に達し

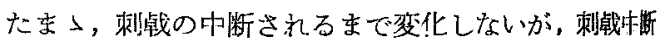
後は緩慢な回復過程を巡る。即ち, 刺战前 $1.9 \mu \mathrm{M} / \mathrm{g}$ て

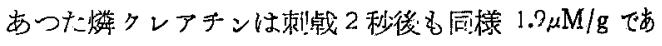
るが，ATP が刺战前に回復する 3 秒後には $\mathrm{i} .3 \mu \mathrm{M} / \mathrm{g}$ ， 5〜 10 秒後は $0.7 \mu \mathrm{M} / \mathrm{g}$ と梄めて急潓に消費される60 の, 15 秒後に $1.1 \mu \mathrm{M} / \mathrm{g}, 20$ 秒後に $1.4 \mu \mathrm{M} / \mathrm{g}$ と漸畑回復

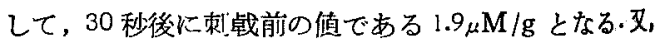

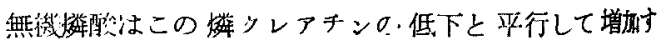

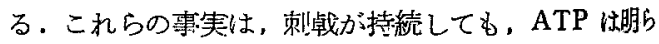
かに燐クレアテンを消費して再合成されるるのと㹲ら れる。

以上の如き，電気刺㦸の結果，in vitro で起る燐酸 临の変化を, in vivo のそれと (Dawson \& Richter, 1950) 比較してみることは脳で起つている幾つかの現象 を理解するのに有力な手がっりとなる・むとより,これ らの垁験に使用ざれた電気刺㦸の周波数や組織内の電任 勾配は in vivo, in vitro ともほ心゙同様であり，邓， 垁験動物の露出大脸皮質に適用して，譏能の活性沈答を 荐起する刺戟とも比較できるものであるが， in vivoて は，液体空気を用いてもな机固定に相当洔閒を要する. 


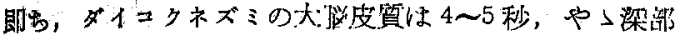
では9〜20秒，イヌ・ネこでは $1 \mathrm{~cm}$ の梁さで30秒を

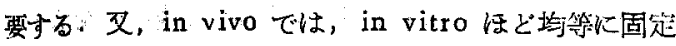
され存いから，燐酸塩の低下繁を in vitro の埗合之同 様な確実さで問䟎にすることはできないが，この二つの 変化は怪同じ析であり，ダイエクネズミでは 1,200〜 $2000 \mu \mathrm{M} / \mathrm{g} /$ 時と考えられるが，この燐酸塭の変動は in vivoでも, in vitroでる共に可逆的である. in vitro に持ける燐タレアチンの回復は慗㦸中断 1 秒後から始ま り. 4 秒儿亘る分解進行過程に比して，回復過程は遥か

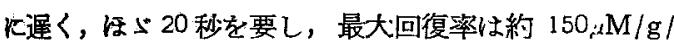
特である・ところが，in vivoでの回復率は更に緩慢で あるが，これは琹らく回復期に痤整活動を伴うためであ Ђ5.

一方，Mc Ilwain 等の精力的な努力にも拘らず，分 離稱組线から活動電位を記録することには未だ成功して いないが，組織の細胞成分は静止膜電位を維持し得るの で，電気刺战が脱分極の原因にはなり得る・响つて，正 常条件下でィンパルスの伝達に䦔与している $\mathrm{K}+$ と $\mathrm{Na}^{+}$ は，電気刺㦸によつて生じた脱分極に伴つて移動し，こ の移動によつて生じたイオン公配の修復には代謝的活動 が必要であり，これに呼吸と解糖の如きニネルギー瓜生 過程が結びついているるのと考えられる。しかし，刺㦸 による雀伝遠に対して Ach が作動すると云らことは 今日殆んど決定的なものとなつている。

ところで，頭部に電気刺棹を適用すると，Ach の低 下江 1 秒以内に開始され，3〜6 秒で起る变化は 0.6〜 $1.2 \mathrm{~m} \mu \mathrm{M} / \mathrm{g} /$ 秒（2〜 $5 \mu \mathrm{M} / \mathrm{g} /$ 洔） の速度で進行するが， 刺战を中断すると急速に回復する・電気刺㦸によるAch

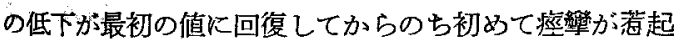

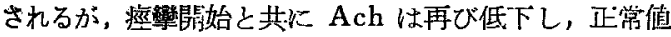

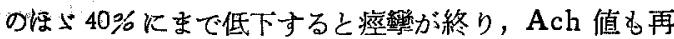
び回復する。この Ach の再合成の最高率は，その最高 水解察の約 1/4である. 従つて，Ach が水解され，再 合成される時間的スケールは，痤變活動に先行するが，

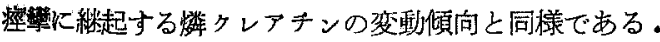
即ち，Ach の座生過程子文梅タレアチンと同様，消費 過程に比して標めて緩慢である。これらの事実は，Ach

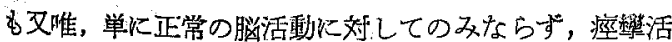
動に対しても消費され，正常の脳活動では Ach の消費

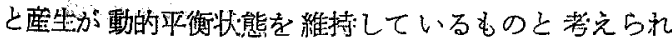
る.

Rowsell 100) に倿れば，ブドゥ糖を基質として呼吸し
ている分離組織比電気刺战を加えると，西吸・解粘の增 大と共に，綃台型 Ach が減少し，ェゼリンの存在下で

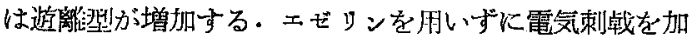
光，Ach 值の低下した脳組織を基筫の存在下㐿吸せ しされば，刺㦸前の Ach 值に回復する.以上の事実に よって，Ach の合成，遊㷰隹及び水解が，末梢神経と同 様無傷の中枢神経柔の機能的活性と䍌接に関連している ことが琵解される・作し，Ach 代謝によるェネルギー 消費を垸定するのは水解ではなく合成である。従つて， Ach の水船に伴う合成に，呼吸や解糖の如きェネルギ 一㘹生渦程が緔びついているものと考えられるが，プド ウ糖の代謝と Ach の形成は間接的な繥びつきである。

Meyerhof と彼の協力者によつて，橉タレアテンは 〜P の唯一の貯蔵物質であり，又，ATP の消費が燐 クレナテンの低下に先行することが証明された。今日， Engelhardt 及び Szent-Györgyi 彼等の協加者によ

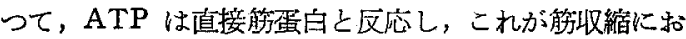
ける第一次の化学次応であるらと信じられている，従つ て，神経の活動時にも餘同橙，ATP の消費は燐クレア チンの消費に先行するものと考えられていたが， Libet

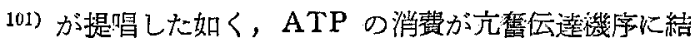
びっいた第一次反灾であるといら考えは，ATP の分解 速度が六鹤伝達に必要な速度に比して，問題にならない 程遅いので，Ach の放出と分解がィンパルスの通過时 に活動する表面卧の变化に留係している反応であつて，

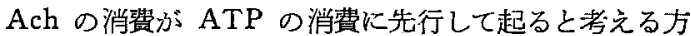
がより罗当であると考えられるようになり，ATPは1 ンパンの伝達中に分解されるAch の再合成に消蒦さ れると考えられている。

Eccles 10:2 によれば,シナップス前部神経湶維のイン パルスが電流を生じ，これが後部細胞のシチップス領域 に二相性の效果を与える・シナップス後部膜に達する䉓

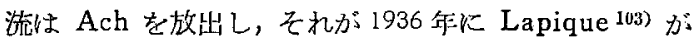
提陧したように反灾連鎖の引企として働いて終板雷位を 発生するエネルギーを供給小る・かくて伝陸されたイン パルスが機能活性の应答を蕧起するわけである。

双，大脳皮質から起る運動投射秝は錐体路，(即ち，

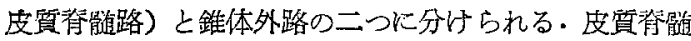
路は，主として Brodmann の4 野と5a野の第V筫に あるべッッ氏細胞に起るが，一部は中心前回及び支心後 回の他の領野の大錐体細胞加ら存起る・一方，錐体外路 系は大脳皮望の多くの領野から起る広洲な投射系である が，これは前頍葉のあらゆる領野と頍頂葉及び側頍葉の 
3-1-2，5，7，22野等から起り，又，後頭葉か、以は特殊 な皮買視床投射と皮賽橋投射が出ている。

錐体路投射は，七下やその他の霊長類では大部分が中 心前回から起る. Holmes 及妓 Page May 1:4) は. 前 頭葉の逆行性変性を検索した絬果，ベッッ升細胞に明膫 な染色質溶解の起つていることを見将して，錐体路は4 野のベッッ氏細胞からだけ出ると結論したが，最近に至 つて, Peele ${ }^{1(5)}$ は, 頭項葉の 2 野と 5b 野の巨大錐体 細胞も又，逆行性変性を起すことを証明した。従つて， これらの領野が度诈学䯣系に関与していることは明らか であるが，その後，Woolsey 及び Chang 16) が新ら しい研究方法をるつて，錐体路投射部位を解明した．即 ち、彼等は，ウサギネニ及びサルの延䯣鐎体を逆行性 に刺战し，皮質から活動電位を記録して，中心前連的領 と頭項葉全体に，将で云えば，Brodmann の6,4, 3-1-2, 5 攰び7 野を含も広範な領野に電位変動を見出 した・が、ウサギでは更に13，22 野からも活動電位を記 録し得た。

ところで，皮質の上肢領域や下肢領域を単独に損稘し た場合に，変性が夫ょ頸檤むるいは腰髄に限局しないこ とを初めて指摘したのは Sherrington であるが，これ は下肢に行く線維が上肢の運動を支配する線維と混合し ているからであり，この事策は久，最初対側の单独運動 に始まるJackson の焦点性発作肪，最後には同側の全 等群になで波及することからも首肯される。

他方，大脳皮質は，皮質春䯙路投射の他に広沉な錐体 外路投射を多くの皮質下中枢に送つているが， Sherrington 107) によると，ある強さの感応電流に対する錐体 外路領域の與奮性は，解剖学的に前頭葉の後部に限局し ているが，前頙葉の與舊性の前方の境界は変化し易く， 束㦸を強くすると運動領域の前にまで执がる・又，この 領域から起る運動は，4野から起る単独の運動に比べて 複雑であり，4野を切除与ると，6野と 3-1-2野の興 雀性が変化する。という事は，6野中 3-1-2野は全て 皮質䢛髄路が完全でない上，弱、刺战に対しては区応し ないためだろら・

頭頂回と 側頍回の 錐体外路領域では, Brown 及び Vogt 1(8) によれぱ，3-1-2 野を刺㦸すると，4野の與 棈性を促進するが，一次的な運動は殆んど見られない。 Foerster 16)にによ狄ば，七トの3-1-2野と5野を刺 战すると，6野と同様に分離した単独の運動や複雑な運 動を起し，分離した運動は 4 野が完全でないと起らない ことを発見した。文，7野は予め璵舊性の促進されて
いる場合には，この領域を刺战すると運動效果を起す (Penfield \& Boldrey ${ }^{110)}$ ) むのと考えられている.

以上の如く，錐体外路性運動投射は，第一下骨格倖系

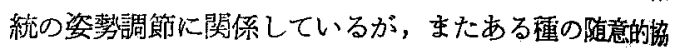
同運動にも関与し，錐体路系運動領之緊密なる関連をb つて高度に体制化された颐動形式を現わすが，更に雓体 外路系のある預野では，特殊な調節機能を持つことか証 明された・そこでここれらの調節袎能について一言触れ てみよう。

前頭葉の眼窝前頍皮質は，Rose \& Woolsey ${ }^{111)} k$ よつて，視床の背内侧核の投射野と定義され，9，10，11， 12 野之眼䆟面の $13 ， 14$ 野が含まれるが，背内側核甠視 床下゙部か、ら重要な線維連絡を受けているので，前幁野が 自律神経㙨能の統合作用，情緒反応に関係があると見做 されているが，9，10，11，12 野の損傷後に見られる脱落 症状惊，単純な反射障碍や熟練運動の障碍にも関系のな いるのであり，䁇万行動様式の变化に関係するものであ る.

前䫀葉の眼䈑面では，既に古くSpencer が，イヌ， ホニ，ウサギ，サルの眼窩回を電気刺㦸した場合，この 四種類の動物では全て呼吸の停止のみならず，血圷の上 昇就いい下降を葓き起すことを見出している・又、 Bailey 及び Sweet 112)によれば，前頍葉の眼裔面に独 立して存在する13 野を刺㦸すると呼吸が停止する，徒 つて，こ」は大脳皮質の第一次呼吸归枢と者えられるよ らになつたが，Smith 113によれば，4野の前下方にあ る6野最下部を弱く刺战すると呼吸運動が抑制され，强 く剌晫すると，恐らくは13 野に刺战が波及与るためで あるう。呼昨運動は完全に停止する・文，Livingston 14) et al はロボトミーに際して，七トの眼窩面を刺踤 し，サルに起ると似た呼吸と血圧の著明な变動を見出 し，更に血管反忘と呼吸反空とは夫ょ独立に起り得るこ とを証明した・13野を切除すると，自律神経障碍加著 明に現われ，Delgadoによれば，両側の13野を町除才

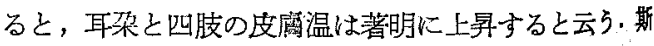
くの如く，眼窝面は，血管運動と呼吸の統合作用以開道 がある。

前頭眼窩回が自律神経機能に密接な関媇をもつている ことは前述した如くであるが，最近になつて，電気唃暲 垁験により，大脳皮質殊に中心前域運動領に種々の自倍 神経機能它再玩が存在することか゚正当に把握評価される に至つた。

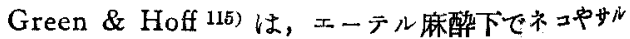




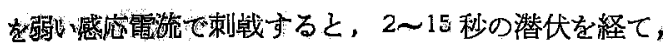

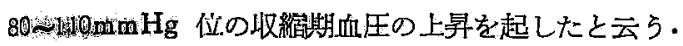

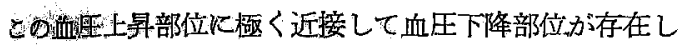

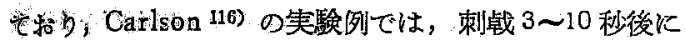
2020 $\mathrm{mmHg}$ 位の収綰期血圧下降が起つている.Hsu et (1117) は，クロラローゼ麻酔下でイ邓の皮質運動領

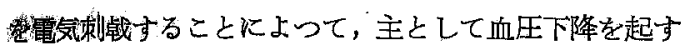
堑告している. Hoff \& Green ${ }^{115)}$ は，血圧上昇部の 刺戟により勘脈圧の上界に伴つて約 $10 \%$ の心搏数の增 加を， 文，血圧下降反応を見る場合には心搏数の半減を

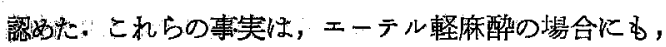
及、タンーレ麻醉の埸合にも確諗された。

皮質を刺战して血圧に变動が現れるのは，末梢血管 の提轨の变北によるためであると想定されるが，ネニと

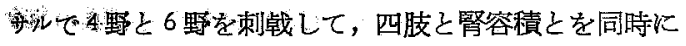
観察した Green と Hoff ${ }^{118)}$ の夷験では，简容積の減 少と同時に四肢容積の堌大か認められ，又，予め四肢か

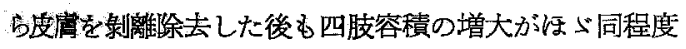
飞起らたことから，この四肢容積の増大は筋への血液供 給の增大に直接起因、するものと考えられる：この事実

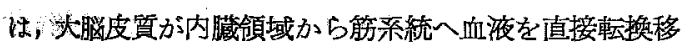

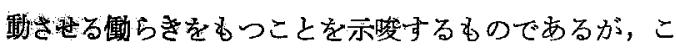
の反疮法四肢の神経除去によつて消失与る.従つて，こ の反分の成立は体液性要因によるものではなく，なんら がの神柽性伝尊路伛よることが明らかになつた。

ところが, Pinkston, Bard \& Rioch 119) 180), Kenn.

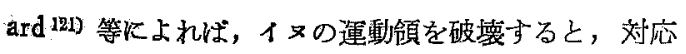
与る四肢には血管收縮よりる寧ろ一般に血管扰張が認め られる。この事実からは，1ヌの運動領に蚂ける血管運 勘の再現は，明らか火血管収綰を司るものであると考え 枫体ならい。

以上述へてをを如く，大脳皮質に牱ける体性神経系の 再靦との間火は広䡉な重なり合いが存在しているがこ の事象こそは，両神経系が現わす反応の間に統合的相互 閍係の成立を可能ならしめるすのである・そこで，大脳

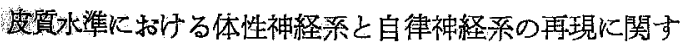
る上述の諸知見に立脚して，大脳皮質の電気刺㦸によ わ，内耳血行がどのように機制され得るかについて検討 都完てるたい.

モルッッの皮質脊咀路は，前頍葉の 4, 6 及び 13 野， 頋㑯葉の 5,7 野之側頭葉の 22 野を含む広範な皮質領野 から起るものと推定されるが，これらの領野からは又，

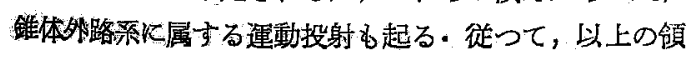

野に電気刺战を適用すれば，当然支配領域の運動応答を 起し，剌㦸の強度によつては皮質内線維連絡により，運 動六進は同側にも波及し，強直性の全身痤街にむで達す ることる起り得る篔である、事実，私の実験例に和いて

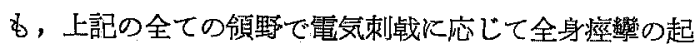

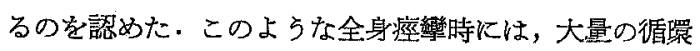
血液が䈈領域へ移動するが，4野と6野の刺戟に際して

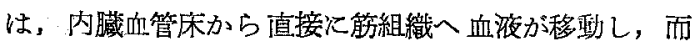
る,この移動は筋の運動自体に上るのではなく, 筋㞄動 を起すインパルスと同じインパルスによつて起るものと 洘えられる・即ら，クラーレで体性運動が抑制されてい る場合にも，4野及び 6 野の刺战により四肢容積の堌大 が同程度に起るからである(Green \& Hofl)：この事実 から，4野と6野に和いては，自律神経系と体性神経系 の再現が互いに雷なり合つて呿り，両神経系の現わす夫 々の反応の間に統合的な相互関係が存立していることは 明らかであるが，4野と6 野の自律神経性調節作用は更 に，心臓・血管系反心として血圧及び心搏数の变動を伴 ら・徉つて，4野と6 野の電気剌戟によつて発射された インパルスは, 一方では, 症變にまで達する筋運動の増 大を起すと同時に，内臓領域上り，即ら，脾藏中の筋組 織と閒脈血管の収縮により，大量の血液を筋領域へ送り 込むと共に，他方では，この血液移動によつて起り得る 脳及び肺血行の制限を椳力抑え得るように，血圧上犁と 心搏六進という調節反店が同期するものと考光られる。 これに反して，4 野及び 6 野と同様, 皮質脊葡路系に属 する5, 7 Z妓び 22 野では, 刺㦸により登射されたインバ ルスが骨格筋の運動克進を若起し，このインバルスは又 同時に血管運動反射を解発して，内葴床から循睘血液の 大量移動を抑ぐが，心臟・血管柔の自律神経柔再現の存 在しないこれら領野の刺㦸に際しては, この緊急且つ大 量の血液移動伴つて，脳血行は極度に制限されること が考えられる・がしかし，からる循澴系の圧变動は大動 脈反射あるいは頸動脈洞反射を解発して，迷走神経内の 非感覚性求心性線䊒にインパルスを送り, 二次的に脳血 行制限を解除へと遒くことであるら。併し，この作为は 軽度である(Ask-Upmark). 従って，4 野と6野の刺 战時に比して，5，7 及び 22 野の刺㦸時に和いては，脳 血行に反映された内耳血行は恐らく一時的であるらが， 強く制限されるものと推測される。

ところで，前頭葉の中心前運動領（4野と6野）は視 床の外腹側核からの体性感覚投射を受けているが，この 中心前回の前炕ある眼窝前頭皮犋と带状回は視床の前核 
と背内側核の投射野で，最近自律神経機能の統合作用に 関係が深いと見做され，機能的に小区劃に区分された。 このうち，12野と13野を含む腿窩前碩皮質は，乳䫓体 朋加ら視床下部の内側核群を経て，視床の背内側核から 投射を受汁ているが，Le Gros Clark 12)によれば， かつる球心性の線倠結合の他认，遠心性線維を視床の背 内側核，視床下部の乳頍体及び下垂体の後葉を神経支配 している視索上一下量体系比塮している。不，Ward \& Mc Culloch 12i) は, ニューロン記録洼により，後眼 裔回（13 野）をストリキニンで刺战すると，後部視床 下野に值接與鹪が起り，前䪽葉の外前面 (12 野)では 視索上核に発射活動を認めている.一一方，後視床下野が

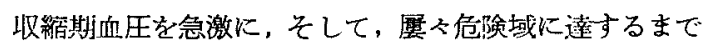
上笔ざせることは周知の事実である. 即ち，Beattic， Brow \& I,ong 124) によれば，視床動物の心搏が非常に 動摇し，心電図の上で期外収縮が見られるが，この期外 収縮性不整脈の 発作は両側星状神経節の剔出により， 及，心葴に達する交感神経節前線維に対応する前根の切 断により，更に延咀内側絿束の切断によつても中断す る.そこで，彼等はその経路を追䟢して，後視床下野が 破壞されると不整脈の消失するのを見た，従つて，この 後視床下野で交感神経系の活動六進が起るものと考えら れる。

以上の事奉から，13野の電気剩战によつて発射され。 たインパルスは，錐体路性の運動元進を起すと共に，後 部視床下野に発射活動を誘発して，心搏克谁，血圧上梨 などの交感神経系の活動をるつて,内臟領域の血液移動 によつて起り得る脳血行制限に対し，抑制的な調節反応 を起すことが考えられる・

他方，視菜上核下垂路仗 Rasmussen 125) 126) によつて 明らかにされたが，この伝導路が资感神経性であるか， あるいは副交感神絰性であるかは未だ確定はされていな いがしかし，Pickford 127） は後葉複合体はコリン作 動性であることを示しており，従つて，視䇣上核は副交 感神経性核であ万うと考えられる。そこで，室房核と視

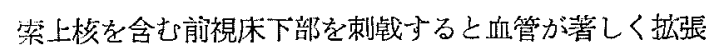
し, 熱变失の機序が解発され, 又, 血圧下降の起ること も理解される (Karplus \& reidl).

そこで, '錐体外路系に属する 12 野の刺㦸によつて起 る運動応答は行動様式の变化であり，従つて，四肢容積 の增大を㥛度に起すとは考光難いが，前視床下部の䝧篦 による血管拉張・血圧下降を起すことは考学られる・併 し，脳血行が血管運動神経によって支配される程度は他
領域と異なり，脳動脈圧の維持にはより强く反応すると

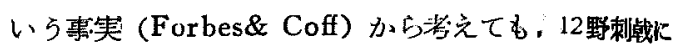
よる脳血管の应張は比較的軽堎に抑えられるであろう。 以上の如き根抛から，大暚皮質刺㦸力゙腷血行を介して

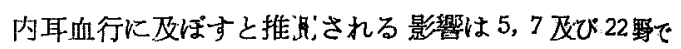
は一過性の高度制限を起し，4，6 及地13野では血行制 限は比較的軽度に抑えられるが，12 野では却つて拉張

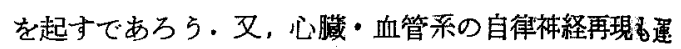
動投射系子存立しない聴覚領の 20 野と視覚領の 17 野の 刺㦸の影響が内耳血行に現われることは考学嚾い。

解つて，私の実駼成續を，斯く推定される内耳血行制 限の面から考察すれば，20里と17 野の刺战で C.M.の 変動が殁んど認められないか,あるいは極めて少ないこ

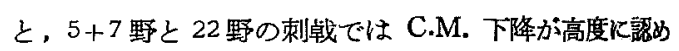
られることは，内耳血行の C.M. に対する意義の重要 性を実証するものであるが，C.M. が内耳血行以の婎 存しているとすれば，4 野の刺战により C.M. の变動加 少ないこと, 又 4 野と同橡な自律神経性の調節反店の再 現をるつ6野と 13 野の刺战で C.M. 下降が高度に現方 れることは説明し難い.この事は，C.M．に対して血行 以外牦要なる意義をむつ因子の存在することを暗示寸 るかのよらである. Weber 128) は C.M. 維持の支配的 因子は，第 1 亿 $\mathrm{O}_{2}$, 第 2 亿血液供給の低下であると述 ベて特り，現在多くの研究者がこの教觉に左怚している が，この考えには極めて重要なる矛盾が含まれている。 即ち，内耳を $\mathrm{O}_{2}$ 供給の面から見れば， $\mathrm{O}_{2}$ は血行劣介 してのみ供給され，而む，血行中の $\mathrm{O}_{2}$ 含量と血行量と が必らずしも平行しないからである。

ところで，13 野は第 1 次呼吸中枢と云われて找り，13 野の刺㦸により呼吸の停止あるいは高度抑制が認めら れ，又，6野の刺幟でも起る呼吸抑制は恐らく刺皒か13 野に波及するためであろらが，呼吸の高度抑制を伴らこ とから，6野と13 野の刺战による C.M. 下浲が4第の それに比して著明に現われることは，内耳血行制限の侱 度によると云うよりは，血行中の $O_{2}$ 飽和度が 4 野飞比

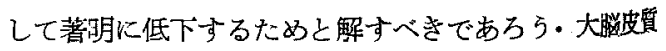
の刺战による血行制限と呼吸抑制から， $\mathrm{O}_{2}$ とブド施 の重要性の優位を決定することはできないが，13野制 皒による C.M. 下降が 急速且つ決定的であることは， C.M. 維持の一義的因子が $\mathrm{O}_{2}$ であることを想定させる. この C.M. 維持に $\mathrm{O}_{2}$ が持つ意義の優位性については， 又中枢神経系の $\mathrm{O}_{2}$ に刘する偖存性からも推測され百。 即台，無傷の動物を電気刺㦸した場合の脳に和ける化学 
变化の速媵から脳内代謝物質を観察すると， $\mathrm{O}_{2}$ の脳内

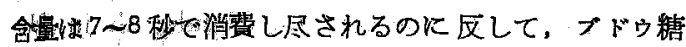
怢４0秒の消費に耐え得ること，更に，グリニーグンと 暽クレナチンの如き代謝物質の貯蔵が存在することは， 胼为最大の较能活性を発揮したり，血行が一時的に遮断

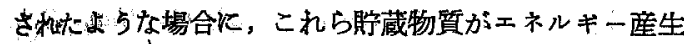
過程娷動員され，機能維持に参劃し得ることから，脳機 能維揞の一義的因子が $\mathrm{O}_{2}$ であることは当然考它られる ところである゙，発生学的系統を同じくする内耳に特い で同棣であるうとも考元られる。

が一方，丸山市内耳動脈の压迫実験からも，C.M. 維 持㶩対する内耳血行量火一定の閏値が存在することは明 らかである・この事は，内耳のエネルギー應生過程と消 費過程との間仁一定の公配があり，この公配が逆転して 初めて機能の低下が現れるるのと考兄られる，従つて， 13 野と6野の刺㦸による内耳血行障碍がたとえ閔值上 の制限であつても，即ら，エネルギーの産生量が消嗐量 より大であっても，その差の小さいことは $\mathrm{O}_{2}$ の供給制

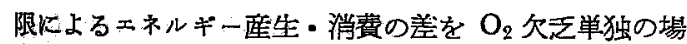
合，例完澕，血中の $\mathrm{O}_{2}$ 飽和度のみを低下せしめた場合 (Gulick) 上りる一層大きく解発することつなる.そこ で，4野の剌㦸によつては C.M. に殆んど影響を及ぼさ なからたと局程度の血行制限でも，13 野と6野の刺㦸 では呼吸抑制あるいは停止の影塑を過大に評佂させる潜 在的因子となつていることは考慮しなければならない電 要な点である・がしかし，内耳血行中の $\mathrm{O}_{2}$ 飽和度をむ つて内耳のンネルギー産生過程を云ミすることは早計で むる・即わ，血行中から内耳へ移行した $\mathrm{O}$ そとブドウ糖 あるいは又，電腃質の豆だけではなく，その代謝率が問 題となろら。

とこるで，大脳皮質水準に和ける自律性統御作用から 内耳血行面を論ずるならば，当然，現在多数の研究者に よつて追求されつ今ある自律神経望心路の想定にも一顧 艺与光ねばなるまい，即ち，Lorente de Nó 129) は， 螖牛の血管怔德神経と共に走る交感神経によつて支配さ れていると云らが, Rasmussen 130) によれば，ナリー プ脚は螺旋神経節が球形霍の枝と合する部位まで追求で きるとし，蝸牛基㷊回転に入る線䊒と合して，Oort の 前庭螖牛神経物合を形成するが，この吻合枝は，形態学 的には求心性線維を含めた自得性遠心路であるという.

か」る線維が礁かに自徨神経遠心路であるならば，恐 らく交感系及び副交感系の遠心性楾維が內耳感覚細胞に 直接達しているすのと考觉られる・又，生体に血行障碍
が起ると，局边に透過性の異常が起ることは周知の事实 であり,生理学的には抵抗性の変動として観察されてい る・そこで，4，6奴 13 野の刺㦸によるインパルスは， 一方では肉耳の血行制限を起し得るが，この血行制限は 局処に透過性の元進を起し，又，他方では自律神程遠心 路を介して誘発される興奮は内耳感覚細胞の透過性亢進 をる起すであろう．胣つて，血行からの基質供給を増大 させると共に，貯蔵代謝物質の動員を容易にし，ェネル ギー産生過程の崩壊を可及的に抑制して，正常機能維持 へと強く働らきかけるすのと考えられる。

ところが，12野の刺战による與奮は副交感性であり， 内耳動脈は拡張に傾くが，副交感性の遠心性線維を介し て，感敩細肘膜の透過性を低下せしめ，血行からの基質 供給抑制之貯葴物質の利用抑制に伴らエネルギー産生過 程の制限から C.M. 下降をきはすと教えられる。

がしかし，及， 12 野浏㦸後の C.M. 下降が副交感系 興奮に拮抗的に起つた交感柔の相刘的與奮のために起つ たと解することるできる。

自律神経系の内耳機能统御は上述の如く，二相性支配 であることが示唆される．即ち，一方には，血管運動神 経の解発による内耳血行の調節が西り，他方，これに答 えて,内耳感覚細胞そのもの興鹤性を統御し，内耳機 能維持に竘所しているものと推测される.しかし，か子 る自律神経系の調節作用は大脳皮質水淮でも再現され， 更に又，皮質水淮では体性神経系の統合的相互作用も祭 密に行われているるのと解される・血中 $\mathrm{O}_{2}$ 飽和度の低 下とか，低血糖に対して C.M. の恒常性がかなりよく維 持されること，又，脳血行制限あるいは遮断に際して， C.M. に比して皮質軋位の变化が早斯且つ高度に現れる こと，更に，C.M. の増大はいかなる条件に対しても起 りにくいのに反して，度質溉位の増大は容易且つ著明に 起ることも以上の点から首肯される・又，脳内貼䵧物買 が檭めて少量であることは，脳が外部の変動に站して敏 感に反応し易いといら利点に立つて，身体機能の統合的 相互作用を高度に体制化しているのに反して，艺れ自体 能機の恒常性を要求される末梢感覚受容器である内咕が 自律神経の二相性支配を受け，更に，体性神経柔との間 にも調節作用を成立せしめていることは，グリコーゲン の販藏量が㯵少で，その分布状態も不定である131 とい ら内耳の機能的特異性の発挒を容易にしているものと考 えられる。

\section{第5章 結 論}

そルモットの大脳发質の電気刺㥂による C.M.の变動 
を罳察して，次の如き結論を得た。

1）錐体路及び 錐体外路系運動投射野である $5+7$ 野 と 22 野では中等度の下降を認めた。

2）錐体路及び錐体外路系運動野であり，且つ心臓・ 血管系の自律神経性再現をむつ4野では極みて変動が少 ないが,

3）これに，更に呼吸系の自律神経性再現が併存して いる6野では中等度，13野では高度且つ決定的な下降 を認めた。

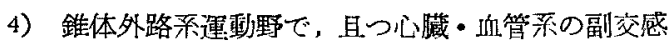
性再現をるつ12野では軽度下降を認めた。

5）㯖覚領の 20 野と視覚領の 17 野では著变を認めな かった。

6）大脳皮筫刺㦸による C.M. 変動は，呼吸抑制・血 行障㥂として作用し，その一義的因子は $\mathrm{O}_{2}$ である。

7）大脳皮質水準に打いて子，自律神経柔と体性神経 系との閂には緊密且つ高度な統合的相互関保が存在 L， 酎神経柔閣の平衡破綻は内耳機能を低下せしむる。

\section{考文 献}

1) Kety, S.S \& Schmidt, C.F.: Amer. J. physiol. 53,$143 ; 1945$.

2) Weber, E.G. \& Bray, C.W.: proc. nat. Acad. Sci., Wash., 16, 344; $1930 . \quad 3)$

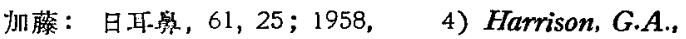
Shemical Methods in Clinical Medicine, 3rd Ed, London; churchill, $1947 . \quad$ 5) Manery, J.F., Biology of Mental Health and Disease, Loudon: Cassell, 1952. 6) Elliott, ${ }^{\mp} K \cdot A . C .,:$ Proc. Soc. exp. Biol., N.Y. 63, 234; $1946 . \quad$ 7) Stren, J.R., Eggleston, L.V., Hems, R.\& Krebs, H.A.: Biochem. J. 44, 410;1946. $\quad$ 8) Terner, C., Eggleston, L.V. \& Krebs, H.A.: Biochem. J. 47, 139; $1650 . \quad 9)$ Krebs, H.A., Eggleston, L.V. \& Terner, C.: Biochem. J. 48, 530; 1951. 10) Aebi, H.: Helv. physiol. pharm. Acta, 11, 96; 1953. 11) Rodnight, R. \& Mc Ilwain, H.: Biochem. J. 57, 939; 1954. 12) Fazekas, J. F., Colyer, H.\& Himwich, H.F.: Proc. Soc. exp. Biol. N.Y. 42, 496; 1939.

13) Himwich, H.E.: Brain Metabolism and cerebral Disorders. Baltimore: Williams \& Rilkius, 1951. 14) Albaum, H.G., Teppermpn, J. \& Bodanshy, O.: J. brol. chcm. 164, 45; $1946 . \quad$ 15) Olsen, N.S. \& Klein, J.R.: Res, Pnbl. Ass. nerv. ment. Dis. 26, 118 ; $1946 . \quad$ 16) Klein, J.R. \&
Olsen, N.S.: J. biol. chem. 167, 747; 1947. 17) Schmidt, C.F.: The cerebral Circulatigh in Health ane Discase, Springfield, Illinois; thomas, 1950. 18) Courtice, F.C : J. physiol. 100, 196; 1941. 19) Dnmke, P.R. \& Schmidt, C.F.: Amer. J. physiol. 138, $421 ; 1943$.

20) Gurdjian, ES. Stone, W.E. \& Webster, J.E.: Arch. Neurol, ps: ychiat. 5 l, 472; 2944. 21) Kerr, S.E.: J. biol chem. 116,$1 ; 1936 . \quad 22)$ Stone, W.E.: Biochem. J. 32, 1908 ; $1938 . \quad 23)$ Richter, D. \& Dawson, R.M.C.: Amer. J. physiol. 154, 73; 19488. 24) Fazekas, J.F. \& Bessman A.N.; Amer. J. Med. 15, 804 ; 1953. 25) Scheinberg,P. \& Stead, E.A.: J. clin. Inre. 28, 1163; 1949. 26) Richter, D. \& Crossland, J.: Amer. J. physicl. 159, 247; 1949. 27) Quastel, J.E., Tennenbaum, M. \& Wheatley, A. H.M.: Biochem, J. 30, 1668; 1936. 28) Stedman, E. \& Stedman, E.: Biochem. J. 31, 817; 1937. 29) Mnn, P.J.G., Tennenbaum, M. \& Ruastel, J.H.: Biochem, J. 32, 243; 33, 822, 1506; 1938, 1939. 30) Korkes, S., Campillo, A. d2l, Korey, S.K., Stem, J.R., Nachmansohn, D. \& Ochoa, S.: J. biol. Chem. 198, 215; $1952 . \quad$ 31) Elliott, K.A.C. \& Penfield, $W .:$ J. Neurophysiol. 11. $485 ; 1948 . \quad 32) M c$ Lennan, H., Elliott, K.A.C.: pharmacol. 103, 35; 1951. 33) Twer, D.B. \& Elliott, K.A.C.: Rer. Canad. Biol. 11, 87; J. appl. physiol. 4, 669; 1952. 34) Tower, D.B.: Epilepsia, 1, 88; $1952 . \quad 35)$ Bernheim, $F .:$ Interaction of Drugs \& Cell Catrlysis, Minneapolis; Buryess; 1946.36$)$ Koelle, G.B. \& Gilman, A.: Pharm.Rev. 1, 166; 1949. 37) Augustinssohn, K.B.: Acta physiol. scand. 16, Suppl. 52; $1948 . \quad$ 38) Whittaker, V.P.: Physiol. Rev. 31, 312; 1951. 39) Nachmansoon, D. \& Rothen berg, M.A.: J. biol. chem. 158, 653; 1945 . 40) Whittaker, V.P.: Biochem. J. 54, 690; 1953 . 41) Feldberg, W.: Physiol, Rev. 25, 596; 1945. 42) Feldberg, W.: Brit. med. Bull. 6, 312; 1949. 43) Nachmansohn, D.: Ann. N.Y. Acad. Sci. 47, 395; 1946. 44) Nachmansohn, D. \& Wilson, I.B.: Adv. Enzymol. 12, 259; 1951. 45) Eccles, J.C: Neurophysiological Basis of Minb, Oxford: Claredon Press; 1953, 46) Utter, M.F., Wood, H. 
\& Reiner, JiM:: J. biol. Chem. 161, 197; 1945. 47) Geiger, A: Biochem. J. 34, 465; $1940 . \quad 48)$ Oaboa S. J. biol. chem. 141,245 ; $1941 . \quad 49$ ) Banga, I. Ochoa, $S$. \& Peters, R.A.: Biochem. J. 33, 1980; 1936. 50) Stone, W.E., Webster, J.E.\& Gurdjipp, E.S.: J. Neurophysiol. 8, 233; 1645, 51) Dạson, R.M.C. \& Richter, D.: Amer. J. physial. 160, 203; 1950. 52) Olsen, N.S. \& Klein J.R.: J. biol. Chem. 167, 739; 1947. 53) Adrian, E.D. \& Moruzzi, G.: J. Physiol. 97, 153; 1939. 54) Eccles, J.C., Fatt, P. \& Koketsu, K.: Australian J. Sci. 16, 50; $1953 . \quad$ 55) Hokin, M.K. \& Hokin, L E.: J. biol. Chem, 209, 549; 1954. 56)

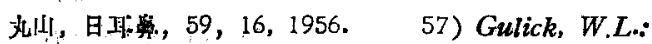
Ann. of O-R-L, 57, 148; $1958 . \quad$ 58) Rüf, H.: Arkiv. f. Psychiat. u. Z. Neūrol., 187, 97; 1951. 59) Stone, W.E.: J. bio!. Chem. 135, 43; 1940. 60) Tower, S.S.: Brain, 59, 408; 1938. Mettler, F.A Ades, H.W., Lipman, E. \& Cu'ler, E.A.: Arch. Neurol, Psychiat., 41,$984 ; 1939$. 62) Dusser de Barenne, J.G. \& Mc Culloch, W.S.: J. Neurophysiol. 1, 69; 1938. 63) Dusser de Barenine, JG. \& Md Culloch, W.S.: J. Neurophysiol, 3, 311; 1941. 64) Kennard, M.A. \& Nims, L.F.: J. Neurophys.o!. 5, 325; 1942.65 6) Kennard, M,A. \& Nims, L.F'.: J. Neurophysiol. 5, 335; 1942. 66) Magoui, H.W. \& Rhines, R.: J. Neurophysiol. 9; 165, $1949 . \quad$ 67) McCulloch, W.S., Graf, C. \& Magoun, H.W.: J. Neurophysiol. 9, 127; 1946. 68) Nulsen, F.E., Blvck, S.P.W., \& Daake, C.G.: Fed. Proc., 7, 86, 1948 . 69) Rard, A.A.: J. Neurophysiol. 10, 89; 1947, 70) Pitts, R.F., Magoun, H.W. \& Ranson, S.W.: Amer. J. physiol. 126, 689; 1939. 71) Magoun, H.W.: Amer. J. physiol. 122, 530; $1938 . \quad 72)$ Connor, G.J.: Proc. Soc. exq. Biol., N.Y., 47, 205; 1941 , 73) Snider, R.S.\& Strowlel, A.: Fed. Proc., 1, 82; 1942. 74) Snider R.S.: \& S, trowell, A.: J. Neurowhysiol., 7, 331; 1944. " 75) Adrian, E.D.: Brain, 66, 289; 1943. 76) Soriano, V. \& Falton, J.F.: Fed. Proc., 6, 207; 1947" 77) Feldberg, W. \& Vogt, M.: J. physiol., 107, 372; 1948. Burgen, A.S.V. \& Chipman, L.M.: J. physiol. 114,
296; 1951. 79) Gibbs, E.L.,Lennox, W.G., Nims, L.F. \& Gibbs, F.A.: J. biol. Chem. 144, 325; 1942. 80) Bornshein, H. \& Krejci, F.: Z. Ohren-usw. Heilk., 13, 190; 1949. 81) Wevre, E.G. etal: Amer. J. physiol., 159, 199; 1949. 82) Gisselson, L.: Acta Otelaryng., 44, 101；1954. 83) 安避:

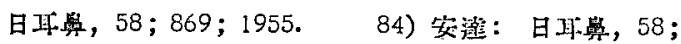
1339, 1955. 85) Tonndorf, J. et al: Ann. Otol. Rhin. \& Laryng., 64, 392; $1955 . \quad$ 86) Fernadez C.: Ann. Otol, Rhin, V Laryng., 64, 1.93; 1956.

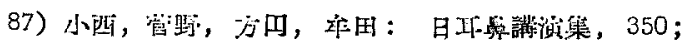
1958. 88) Lawrence, M. \& Wever, E.G.: Arch. Otelaryng., 55, 31;1952. 89) Kimura, R.: Ann. Otol. Rhir. \& Laryng., 65, 333; 1956.9 90) Libet, B. \& Grard, R.W.: J. Neurephysiol. 2, 1939. 91) Burns, B.D.: J. physiol. 111, 50; 1950 . 92) Burns, B.D.: J. physiol. 112, 156; $1951 . \quad$ 93) $\boldsymbol{M C}$ Ilwain, H., Euchel, L. \& Chestrire, J.: Biochem. J. $8 ; 12 ; 1651, \quad$ 94) Gore, M., Ibbott, F. \& Mc Ilwain, H.: Biochem. J. 47,I 121 ; 1950.95$)$ 95) Ilwasn, H.: Biochem. J. 55, 618; J. Neurol. Neurostrg. PsicCiat. 71, 488; 1954 . 96) Noell, W.K.: J. cell, comp. Physiol. 37, 283; 1951. 97) Heald, P.J.,Mc Ilwain, H. \& Nelligan, D.: Biochem. J. 56. Xl Viii; 1954.98$)$ Heald, P.J.: Biochem. J. 57,673 ; 1954.99 9) Heald, P.J.: Biochem. J. 56. XI viii; 1954. 100) Rowsell, E.V.: Biochem. J. 57, 666, 1954 . 101) Libet, B.: Biol. Bull., 83, 219; 1947. 102) Eccles, J.C.: Ann. N.Y. Acad. Sci., 47, 429; 1946. 103) Lapique, L.: C.R. Soc. Biol, Paris, 122, 990; 1936.1 104) Ho'mes, G. \& May, W. Page: Brain, 1. 1907. 105) Peele, T.L.: J. Comp. Neurol., 77, 693; 1942. 106) Woolsely, C.N. \& Chang, H-T.: Res. Publ. Ass. nerv. ment. Dis., 27, 146; 1948. 107) Sherrington, C.S. \& Leyton, A.S.F.: Quart. exp. physiol., 11, 135; 1917. 108) Vogt, O. \& Vogt, C.: J. physiol. Neurol. LpZ., 25, 277, $1919 . \quad$ 109) Fuerster, O.: Handb. Neurol., 9, 1 ; 1936.110 ) Penfield, W. \& Boldrey, E.: Brain, 60, 389; 1937. 111) Rose, J.E. \& Woolsey, C.N.: Res. Publ. Ass. nerv. ment, Dis., 27.210 ; $1948 . \quad 112)$ Bailey, $P$. \& Sweet, R.H.: J. Neurophysiol., 3, 276; 1940. 
113) Smith, R.K.: J. Neurophysiol., 1, 55; 1938. 114) Livingston, R.B., Chapman, W.P., Livingston, K.E., \& Kraintz,L.: Res. Publ. Ass. nerv. ment. Dis., 27, 421 ; 1948. 115) Hoff, E.C. \& Green, H.D.: Amer. J. Physiol., 117, $411 ; 1936$. Carlson, H.B., Gellhorn, E. \& Darrow, C.W.: Arch, Neurol. Psychiat.: 45, 105; 1941. 117) Hsu, $S-H$, Hwang, $K$. \& Chu, $H-N$. . Amer. J. Physiol. 137, 468; 1942.

118) Green, H.D. \& Hoff, E.C.: Amer. J. Physi5l., 118, 641; 1937. 119) Pinkston, J.O., Bard, P. \& Rioch. D. Mck.: Amer. J. physiol. 109, 515; 1954.

120) Pinkston, J.O. \& Kioco, DMck.: Amer. J. physiol. 121, 49; 1638. 121) Kennard, M.A.: Bumke. u Foersters Hamdb. Neur71., 2, 476; 1937, 122) Clark, W.E. Le Gros.: Lancet, 254, 353; 1948 . 123) Ward, A.A. Jr. \& Mc Culloch, W.S.: J. Neurophys pl. 10,309; 1947.
124) Beattie, J.,Brow, G.R. \& Long, C.N.H.: Res. Publ. Ass. uerv. ment. Dis., 9, 249, 295; Proc. roy. soc., 106 B, 253; 1930.

125) Rasmussen, A.T.: Res. Publ. Ass. ntrv. ment. Dis., 20, 245; 1990. 126) Rasmussen, A.T:: Endocrinology, 23, 263: 138. 127) Pickford, M.: J. physiol, 106, $264: 1947 . \quad 128)$ Weber, E.: Bull, Histol, Tech. M., 24, 49 ; 1947. 129) Lorentede No, R.: Laryngoscope, 47, $376 ; 1937 . \quad$ 130) Kasmussen, A.T: J. comp. Neurol. 131) 琏辺：日.4.莮, 30,$314 ; 1921$.

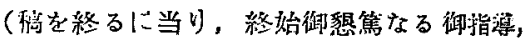
部校開を賜つた恩所後藤修二教授に゙深謝する)。

（原稿到着＝咀炤 34.4 .21 日一急載）

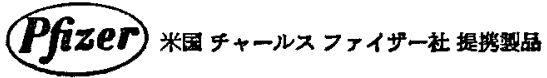
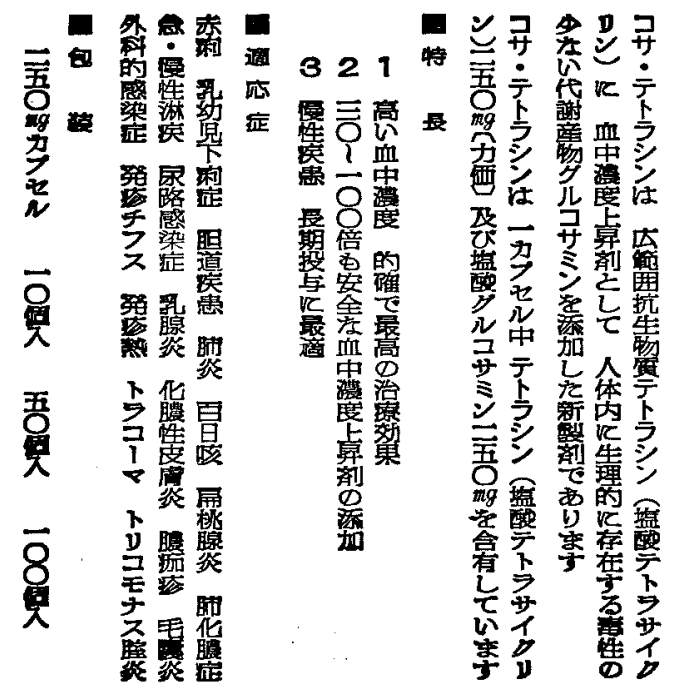

(19)

台糖ファイザー株式会社

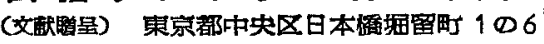
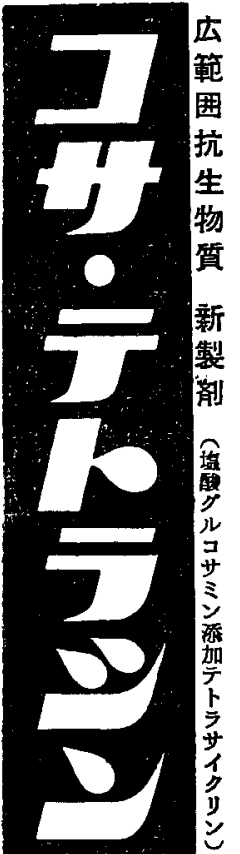

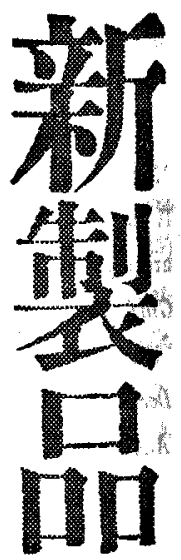
加濃 し
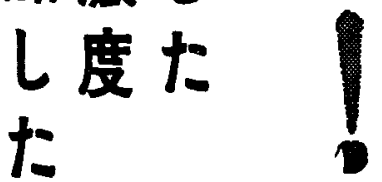

上安非 昇全常 剤なに 血進 添中步 t:

: 